\title{
Preparation and Structural Characterization of Alkaline Earth-Iron(III) Layered Double Hydroxides and their Acrylate-Intercalated Derivatives PhD Dissertation
}

\author{
Dávid Ferenc Srankó \\ Supervisors: $\quad$ Dr. Pál Sipos \\ Dr. István Pálinkó
}

\begin{abstract}
Doctoral School of Environmental Science
Material and Solution Structure Research Group

Department of Inorganic and Analytical Chemistry

Department of Organic Chemistry
\end{abstract}

Faculty of Science and Informatics | University of Szeged

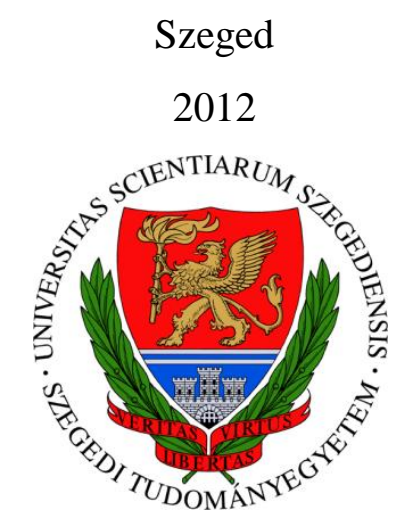




\section{TABLE OF CONTENTS}

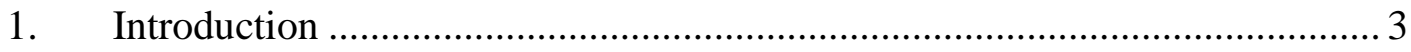

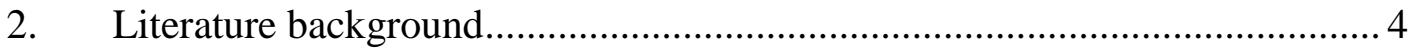

2.1. Layered double hydroxides - what they are and what they are good for........ 4

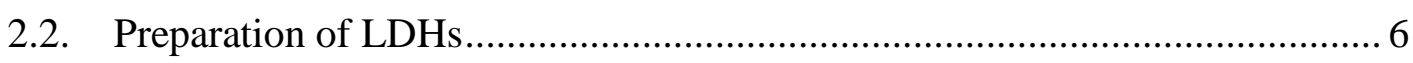

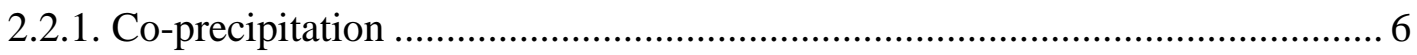

2.2.2. Further methods of LDH preparation ...................................................... 7

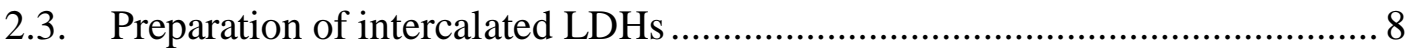

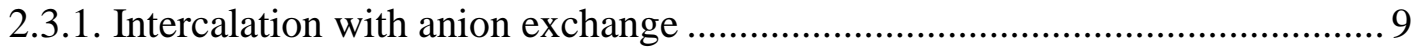

2.3.2. Intercalation with the dehydration-rehydration method ............................... 10

2.4. Preparation and application of iron based LDHs ..................................... 11

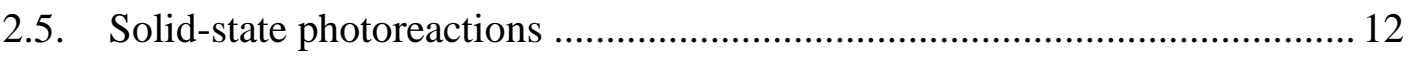

2.5.1. Topotactic photodimerization in the solid state ......................................... 13

2.5.2. Topotactic photodimerization in the confined space of LDH...................... 14

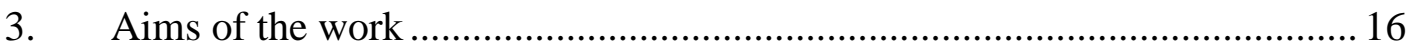

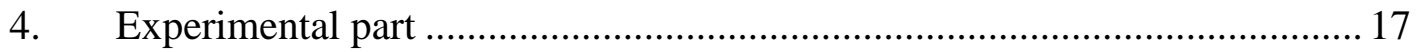

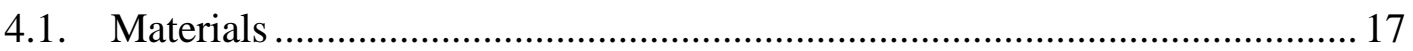

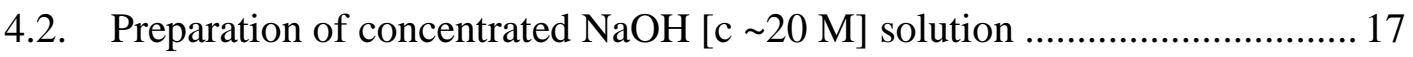

4.3. LDH syntheses with concentrated $\mathrm{NaOH}[\sim 10-20 \mathrm{M}]$ solution using the

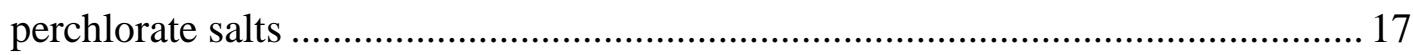

4.4. LDH syntheses with $\mathrm{NaOH}[\mathrm{c}=3-5 \mathrm{M}]$ solutions using the chloride salts . 18

4.5. Preparation of the organic-inorganic nanocomposites ................................ 18

4.5.1. "Ex situ" hydrothermal process (the rehydration-dehydration method) ........ 18

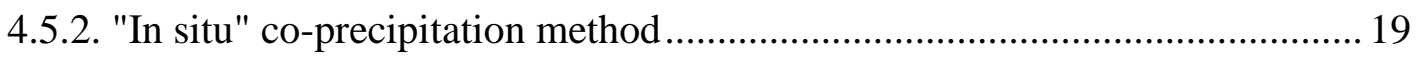

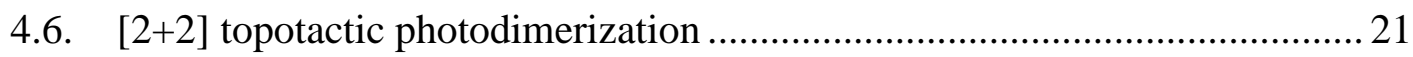

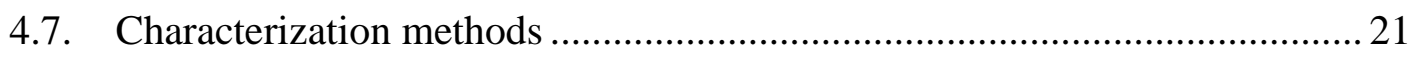

4.7.1. Thermal analytical measurements .......................................................... 21

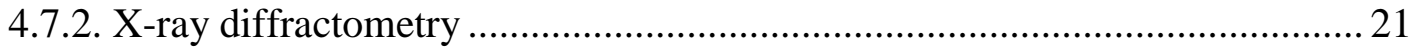

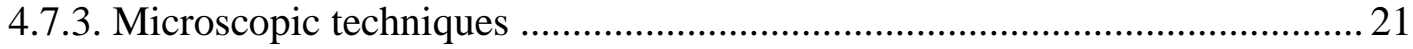

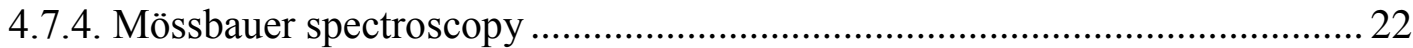

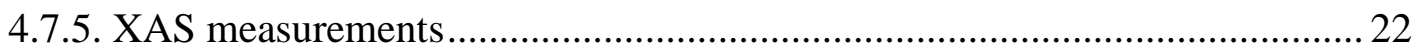

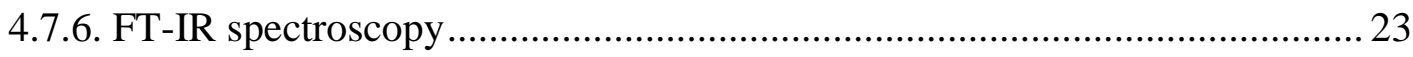




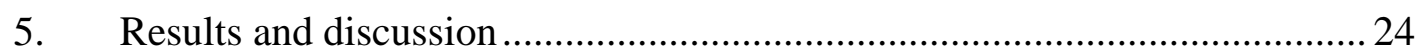

5.1. Preparation and characterization of alkaline earth metal ion/Fe(III) double hydroxides.

5.1.1. Syntheses and characterization of $\mathrm{Ba}(\mathrm{II}) \mathrm{Fe}(\mathrm{III})$ layered(?) double hydroxide .25

5.1.2. Structural characterization of $\mathrm{Ba}(\mathrm{II}) \mathrm{Fe}(\mathrm{III})$ layered double hydroxide 30

5.1.3. Syntheses and characterization of $\mathrm{Mg}(\mathrm{II}) \mathrm{Fe}(\mathrm{III})$ and $\mathrm{Ca}(\mathrm{II}) \mathrm{Fe}(\mathrm{III})$ layered double hydroxides

5.1.4. Syntheses and characterization of $\mathrm{Sr}(\mathrm{II}) \mathrm{Fe}(\mathrm{III})$ layered(?) double hydroxide 47

5.2. Structural characterization of organic-inorganic LDH composites ................ 51

5.2.1. Characterization of propenoate derivative- $\mathrm{Ca}_{3} \mathrm{Fe}-\mathrm{LDH}$ by XRD ................51

5.2.2. Characterization of propenoate derivative- $-\mathrm{Ca}_{3} \mathrm{Fe}-\mathrm{LDHs}$ by scanning electron mic-roscopy 55

5.2.3. Characterization of propenoate derivative $-\mathrm{Ca}_{3} \mathrm{Fe}-\mathrm{LDHs}$ by energy dispersive $\mathrm{X}$-ray analysis (coupled to scanning electron microscopy) 59

5.2.4. Characterization of propenoate derivative- $\mathrm{Ca}_{3} \mathrm{Fe}-\mathrm{LDHs}$ by FT-IR spectroscopy 61

5.3. [2+2] topotactic cyclic photodimerization of propenoate derivatives using $\mathrm{CaFe}-\mathrm{LDH}$ as nanoreactor .68

5.3.1. Topotactic reaction of E-3-phenylpropenoate and its intercalated form .73

5.3.2. Topotactic reaction of E-3(4'-nitrophenyl)propenoate and its intercalated form .74

5.3.3. Topotactic reaction of E-3(2'-thienyl)propenoate and its intercalated form.. 76 5.3.4. Topotactic reaction of E-3(2',5'-difluorophenyl)propenoate and its intercalated form .77

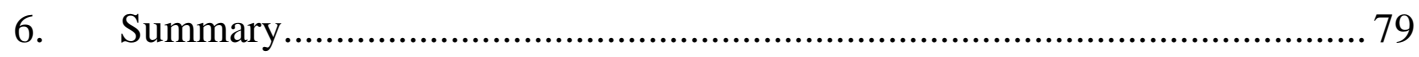

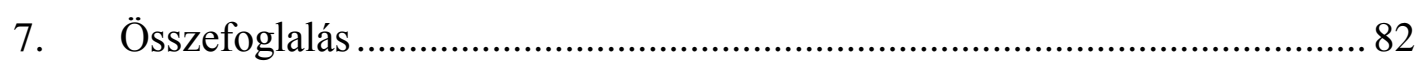

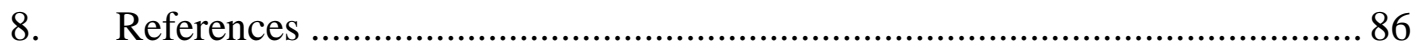

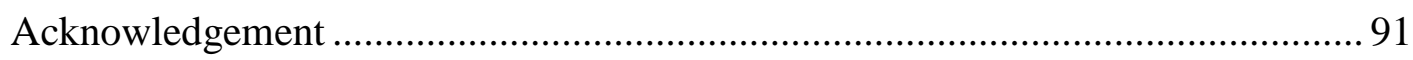




\section{INTRODUCTION}

The wide range of existing building blocks having nanostructure either of organic or inorganic origin offers several alternatives for applying them in the development of diverse fields like drug delivery, catalytic applications, reactions benign to the environment, various kinds of functional nanomaterials and formulating novel concepts, e.g. influencing reaction selectivity through using them as nanoreactors, etc.

This latter area is especially promising in environmental applications, because layered materials or clay minerals are friendly to the environment, they offer confined spaces useful not only for storing various anions, but facilitating reactions with increased selectivity as well as allowing the controlled release of drugs, pesticides, etc.

Layered materials are versatile, they can easily be tailored for various wide-ranging applications starting from simple storing of, e.g. enantiomeric anions and delivering them to the place of synthesis, through thin solid films for different electronic or magnetic applications to constituents of fuel cells. 


\section{LITERATURE BACKGROUND}

\subsection{Layered double hydroxides - what they are and what they are good for}

Layered double hydroxides (LDHs) are anion-intercalated inorganic functional materials, also known as hydrotalcite-like compounds or anionic clays [1-3]. Some representatives are found in nature, and others are synthesized for many types of

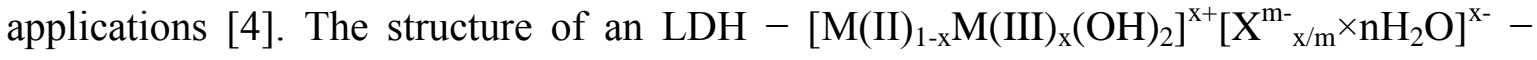
(Fig. 1) is similar to that of brucite, $\left(\mathrm{Mg}(\mathrm{OH})_{2}\right)$, but the octahedrally coordinated divalent metal ions (M(II)) are partially and isomorphously substituted for trivalent ones (M(III)) [5-7].

Monovalent metal ions, e.g. $\mathrm{Li}^{+}$and tetravalent metal ions, e.g. $\mathrm{Ti}^{4+}$ can be also be used to synthesize LDHs [8,9]. Elements described in the literature as components of the layers are shown in Fig. 2.

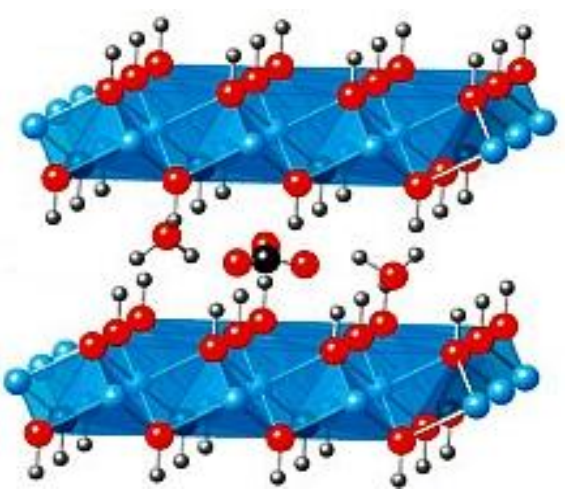

Fig. 1 The schematic structure of a layered double hydroxide (LDH).

The Periodic Table of the Elements

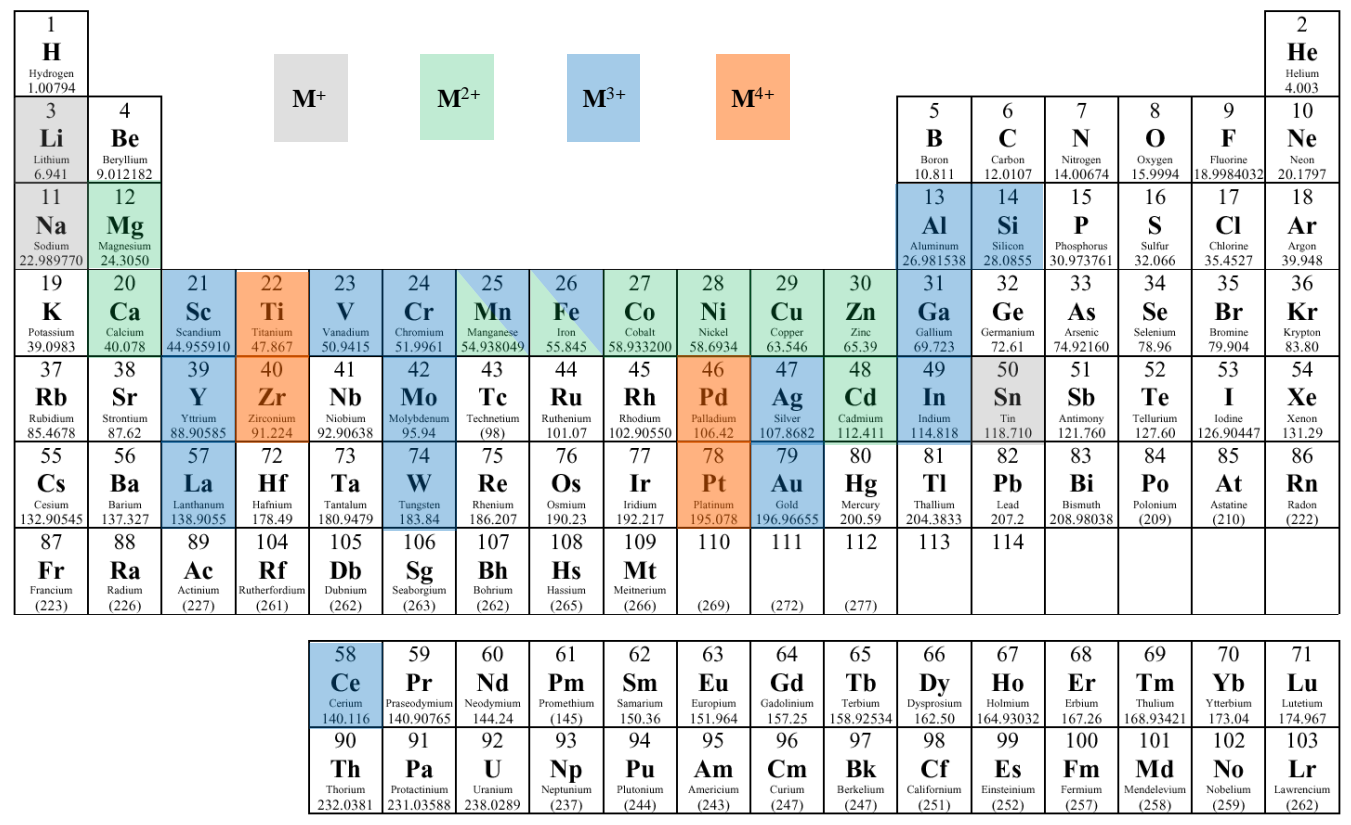

Fig. 2 Elements used so far in the syntheses of LDHs. 
It has been learnt that these materials can easily be tailored, not just by varying the constituent ions; the alteration of the synthesis parameters may also modify the macroscopic structural properties of the LDHs. Although the most common representative, the (natural) hydrotalcite has been known for over 150 years, its structure has been determined long time ago [10] and the structural aspects of its synthesized version are well investigated, a lot of unanswered questions remained concerning the behavior under various circumstances, modification and application possibilities of other LDHs. There is also room for discoveries regarding the hydrotalcite itself.

Applications of LDHs range from their usage as catalysts precursors [4] to biomedical applications [11]. There are three main lines in the research activity concerning LDHs: (i) the preparation of novel LDHs, (ii) the intercalation of organic or inorganic anions into the LDH host and (iii) exploring novel applications as functional nanomaterials. The synthesis, modification and use of LDHs are blossoming area of research, the number of related papers reached 2000 until the year 2012 basically starting from the 80 s of the previous century (Fig. 3).

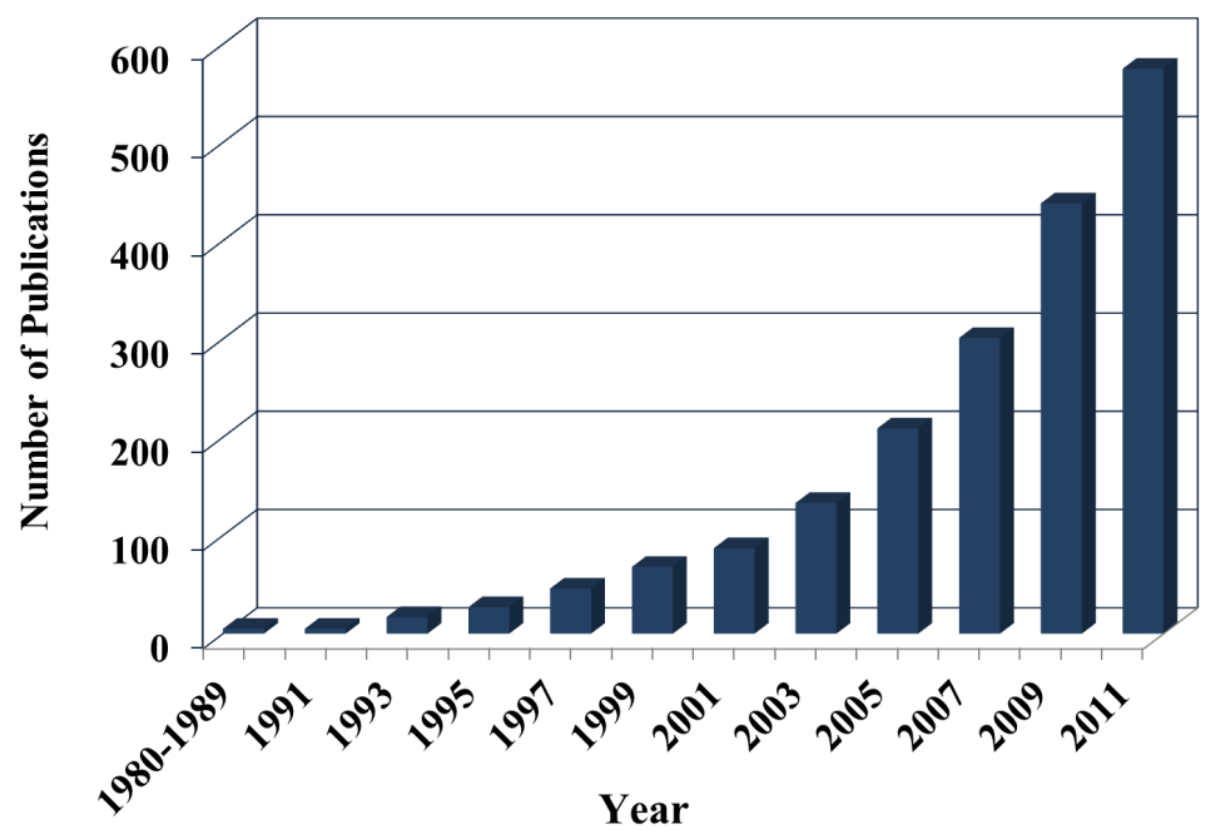

Fig. 3 Number of published articles vs. year related to layered double hydroxides.

Preparation of LDHs with novel composition seems to be limited by the widely accepted statement, (I should say dogma, detailed below), assuming that the ionic radii of the di- and trivalent ions should be similar [1]. This prerequisite limits the ions (or their combinations) to participate in $\mathrm{LDH}$ formation, however, their ratios may change widely still giving many substances to this family. 


\subsection{Preparation of LDHs}

The simplest and the still most often applied mode for the synthesis of LDH is the co-precipitation method [12]. This is the easiest way to produce LDH in copious quantities. Of course, this method has disadvantages like the relatively poor reproducibility and control of particle size and crystallinity, therefore much effort was devoted to its improvement (precipitation at low $[13,14]$ or high $[15,16]$ supersaturation) and invention of other preparation routes (a method involving separate nucleation and aging steps (SNAS) [17], urea hydrolysis [18,19], salt oxide (or hydroxide) [20], mechanochemical [21], etc.). These methods will be summarized in the followings.

\subsubsection{Co-precipitation}

This method is the most commonly used preparative technique to synthesize LDHs, because it is easy to perform and produces large amount of the product. In general, nitrate or chloride salts of the metal ion are used for the synthesis, because of their low affinity to the positively charged layers, allowing easy modification of the interlayer anion fitting to the specific needs.

Two modifications of the methods were elaborated. The first is precipitation at low supersaturation [13,14]. It is performed at constant $\mathrm{pH}$, thus it is also known as precipitation at constant $\mathrm{pH}$. The essence of this method is the slow addition of the solution containing both the di- and trivalent metal ions to the aqueous solution of the anion, which will be intercalated in the precipitated LDHs. The $p \mathrm{H}$ is held constant and the precipitation is facilitated by the simultaneous addition of alkaline solution to the reactor with an appropriate rate. The reaction can be followed by monitoring the $\mathrm{pH}$. The advantage of the method is the high precision control of the ratio of $\mathrm{M}(\mathrm{II})$ to $\mathrm{M}(\mathrm{III})$, thus the charge density of the layers.

Precipitation at high supersaturation is somewhat simpler $[15,16]$. The $p \mathrm{H}$ during the synthesis is variable until its end. Solution containing M(II) and M(III) ions is added to an alkaline solution, in which the LDH precipitates. The counter ion (the anion between the layers) will be the anions in the alkaline solution, the hydroxide ion that is, if a highly concentrated $\mathrm{NaOH}$ solution is used. The continuous change in the $p \mathrm{H}$ during the synthesis may result in the formation of secondary products, such as $\mathrm{M}(\mathrm{OH})_{2}$ and/or $\mathrm{M}(\mathrm{OH})_{3}$, thus an unplanned and perhaps undesired ratio of $\mathrm{M}(\mathrm{II})$ to $\mathrm{M}(\mathrm{III})$ in the $\mathrm{LDH}$. The method gives 
less crystalline materials because of the high number of crystallization nuclei. Thermal treatment after the synthesis may help to improve crystallinity.

Any of these techniques is suitable for the preparation of Fe(III) based LDHs and I have applied the latter one throughout my experimental work described in this dissertation.

\subsubsection{Further methods of $L D H$ preparation}

As it has been mentioned, the biggest disadvantage of the co-precipitation method is that it yields of LDHs with low crystallinity and largely varying particle size. The method of separate nucleation and aging steps (SNAS) [17] and the urea induced hydrolysis technique $[18,19]$ are used to eliminate or at least minimize these drawbacks.

The SNAS method is excellent to control the size distribution [17]. It is based on the very rapid mixing of the components in a colloid mill, thus accelerating the nucleation process. The following step, ageing that is, takes place separately (Fig. 4). This method is one of the significant competitors of co-precipitation in the every-day practice. The disadvantage of this method is the high cost of the required equipment.

Larger crystals with better crystallinity can be obtained using the urea method $[18,19]$. Urea is a weak Brønsted base, soluble in water and the urea-induced hydrolysis can easily be controlled by the temperature. The obtained products are homogenous in size and the crystals have well-defined hexagonal shape making this preparation technique very attractive (Fig. 5). The method is limited to the synthesis of LDHs with specific cations and the anions in the interlayer space are usually carbonate ions, which cannot readily be altered.

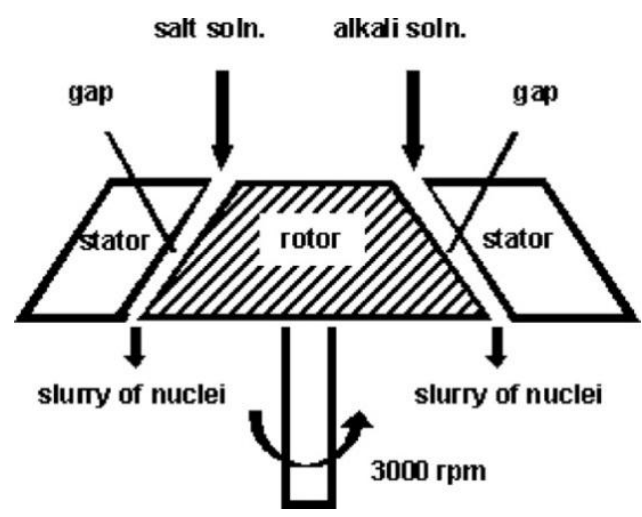

Fig. 4 Schematic illustration of a colloid mill. 


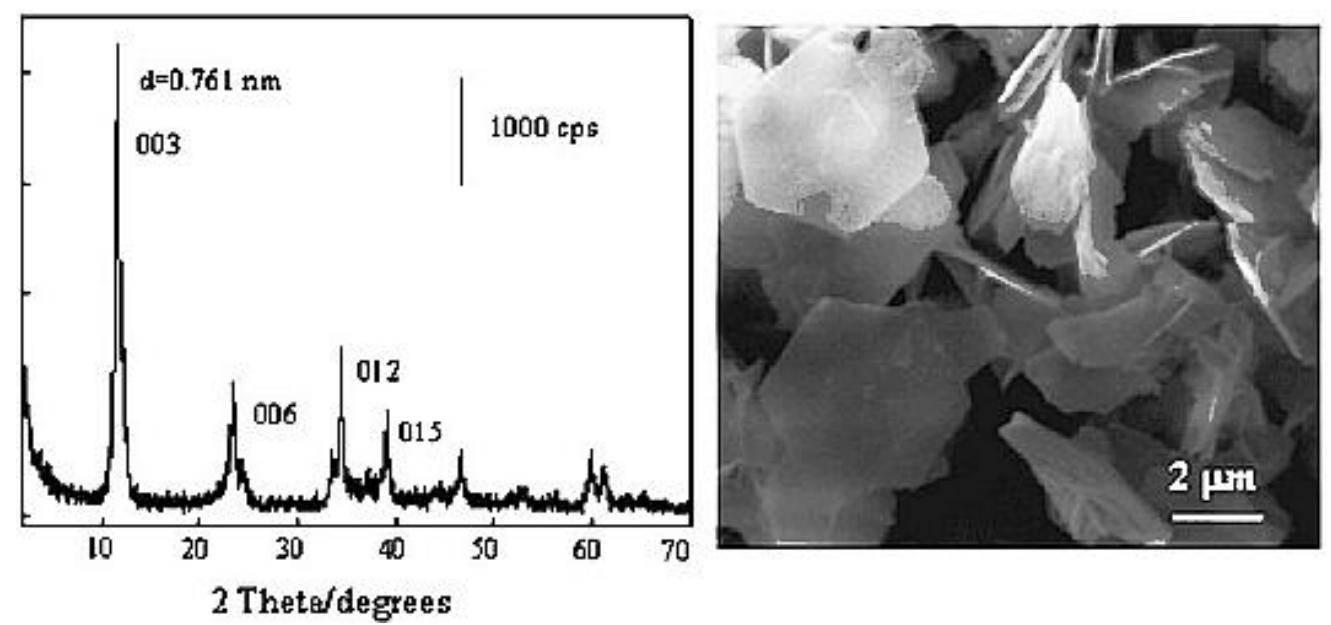

Fig. 5 Typical XRD pattern and SEM image of Ni(II)Fe(III)-LDH synthesized by the urea method [19].

Preparation of LDHs using salts and oxides as metal ion sources was first applied for $\mathrm{ZnCr}-\mathrm{Cl}-\mathrm{LDH}$ [20]. Ageing of trivalent metal ion hydroxide/oxide gels in divalent metal salt solutions led to the formation of the $\mathrm{LDH}$.

Energy needed for the synthesis of an LDH may be transmitted by mechanochemical means, e.g. by ball-milling. This way, the NiFe-LDH has been prepared recently [21].

\subsection{Preparation of intercalated LDHs}

Intercalation is one of the important ways of significantly modifying the structure and functionality of the layered materials. The definition of the intercalation of clay minerals by Lagaly et al. is "the penetration of organic molecules into the interlayer space of clay minerals; intercalated guest molecules can be displaced by other suitable molecules" [22].

Intercalation may be performed in various ways like secondary intercalation (the pre-pillaring method) [23,24], dehydration-rehydration using the memory effect of the LDH (the layered structure collapses on dehydration but it is reconstructed on rehydration [25]), direct ion exchange [26], hydrothermal methods [27,28], intercalation in the presence of additives like glycerol [29], dissolution and re-co-precipitation [30,31], etc.

The intercalated anions can be simple inorganic anions like $\mathrm{CO}_{3}{ }^{2-}[14,32-35]$, $\mathrm{NO}_{3}{ }^{-}$[13], etc., large robust inorganic anions like homo- or heteropoly acid anions, simple or complicated organic anions or negatively charged metal complexes of various kinds. 
The anion to be intercalated is largely determined by the aimed application. The composites incorporating the anions can be systems of controlled and targeted release (of medical compounds, pesticides), stabilizers of reactive compounds, etc. Anions of many biomolecules or pharmaceutical agents were intercalated, such as amino acids [36-43], polyamino acids [41], nucleoside monophosphates and deoxyribonucleic acid (DNA) [44], vitamins (A, E, C) [45] and anti-inflammatory drugs [46-48]. Catalysts or catalyst precursors (like polyoxometalate anions [49] and catecholate [50]) were also intercalated.

For the intercalation the anion-exchange and the dehydration-rehydration methods are used most frequently, therefore, some details of them will be given in the followings.

\subsubsection{Intercalation with anion exchange}

In the anion-exchange method, the guest anions are exchanged with those in the interlayer space of LDH. Several factors determine the outcome and extent of the process like the affinity for the incoming anion, the medium of the exchange, the $\mathrm{pH}$, the chemical composition of the layers, etc. The affinity depends on the charge and the ionic radius of the incoming anions. The sequences for the divalent and the monovalent anions are $\mathrm{CO}_{3}{ }^{2-}>\mathrm{HPO}_{4}{ }^{2-}>\mathrm{SO}_{4}{ }^{2-}$ and $\mathrm{OH}^{-}>\mathrm{F}^{-}>\mathrm{Cl}^{-}>\mathrm{Br}^{-}>\mathrm{NO}_{3}{ }^{-}>\mathrm{I}^{-}$, respectively. The method favors the intercalation of the carbonate ion. If it is not wanted the preparation must be carried out under inert atmosphere to avoid airborne $\mathrm{CO}_{2}$. In the preparation of the starting LDH, usually nitrate salts are applied, thus, one has the possibility of altering the ion with relative ease. Usually, the exchange medium is aqueous, however, using organic solvent or at least aqueous organic medium favors the exchange to organic anions. The effect of $p \mathrm{H}$ is of importance, since the anionic form is to be introduced.

Using this method, various inorganic and organic anions could be intercalated like carboxylates [51], surfactant anions [52], phosphonates [53], $\beta$-cyclodextrin wrapped molecules [54], anionic forms of poly(ethylene oxide) derivatives [55], polystyrene sulfonate [56], anions of pharmaceutically active molecules [57,58], biomolecules [59], amino acids [39], glyphosate [60] dye anions [61,62], metal oxo species [63,64], polyoxometalates $[65,66]$, phosphate ions $[67,68]$ and anions of metal complexes [69-78], etc. 


\subsubsection{Intercalation with the dehydration-rehydration method}

Another frequently used method, the dehydration-rehydration one is based on the memory effect of LDHs [25]. The layered structure of LDH is destroyed by heat treatment (the applicable temperature depends on the $\mathrm{LDH}$, however, it should not exceed $773 \mathrm{~K}$. If it is higher, the loss of the layered structure becomes irreversible). The heat-treated sample is rehydrated with the desired anion dissolved in an aqueous organic solvent (most often aqueous ethanolic solvent is used). Relative humidity and temperature are important variables in this procedure [79].

Dehydration occurs in four major steps [80]:

(i) continuous dehydration process and dehydroxylation of layers, between room temperature and $250^{\circ} \mathrm{C}$,

(ii) interlayer anion decomposition, between 250 and $350^{\circ} \mathrm{C}$,

(iii) shrinkage and then collapse of the layered structure, between 350 and $550^{\circ} \mathrm{C}$

(iv) crystallization of new phases.

The four steps and their activation energies for $\mathrm{MgAl}-\mathrm{CO}_{3}-\mathrm{LDH}$ are depicted in Fig. 6 in the function of conversion $(\alpha)$ by the modulated thermogravimetric and the isoconversion methods.

The schematic representation of an LDH structure with the interlayer anions $\left(\mathrm{CO}_{3}{ }^{2-}\right)$, structural $\mathrm{OH}$ groups and physisorbed water interconnecting the anion and the structural $\mathrm{OH}$ groups are seen in Fig. 7.

Rehydration probably occurs similarly, except that the steps are reversed and the quality of the anion determines the final intercalated structure.

By this method practically the same kinds of anions could be intercalated as with ion-exchange. The method to be chosen cannot be predicted, however. One must try both and should stick to the more successful one. During my work the dehydration-rehydration method proved to be more successful than the anion exchange. 


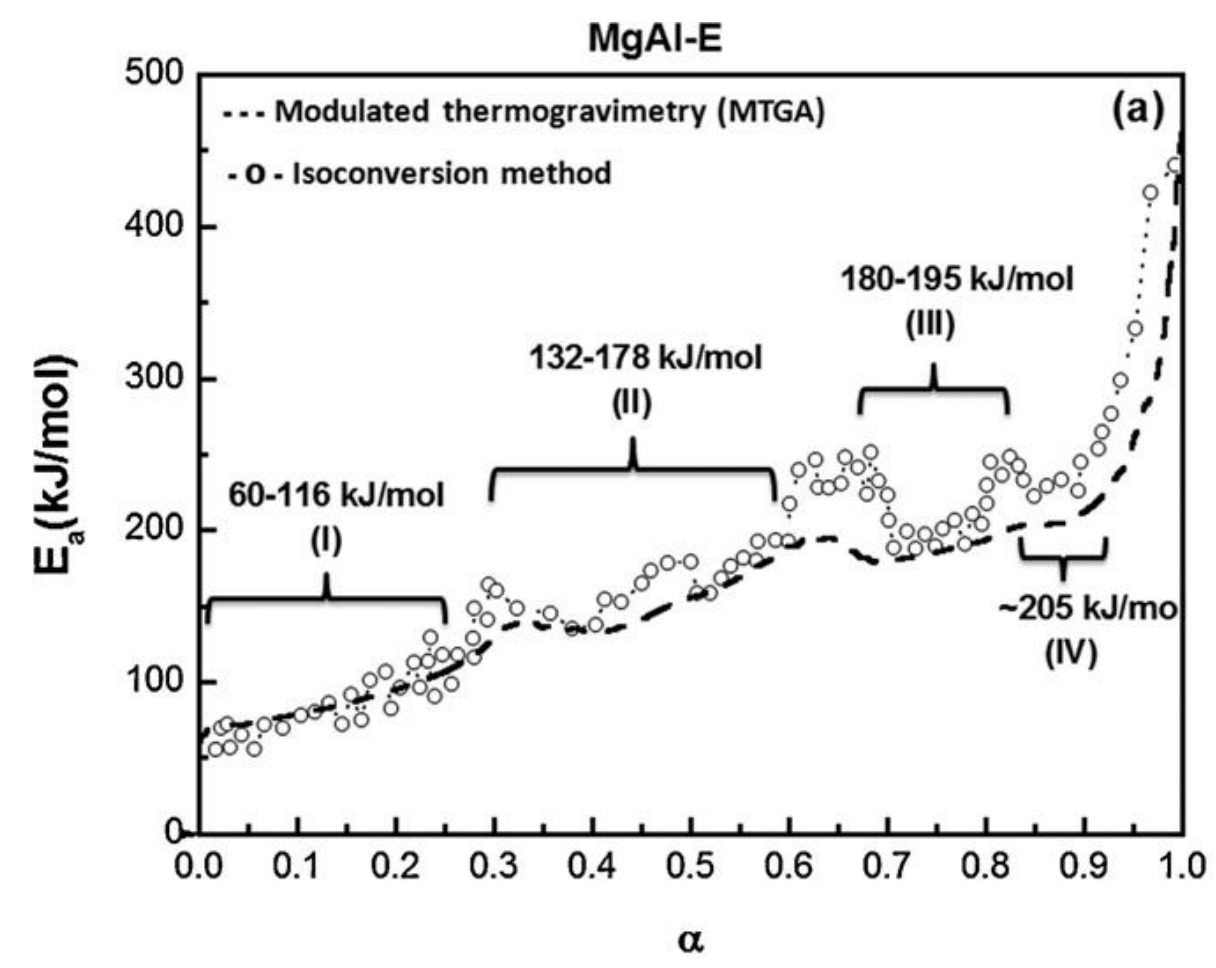

Fig. 6 Dependence of activation energy $\left(E_{a}\right)$ on the degree of conversion $(\alpha)$ of dehydration by modulated thermogravimetry and the isoconversional method for MgAl-LDH (MgAl-E) [80].

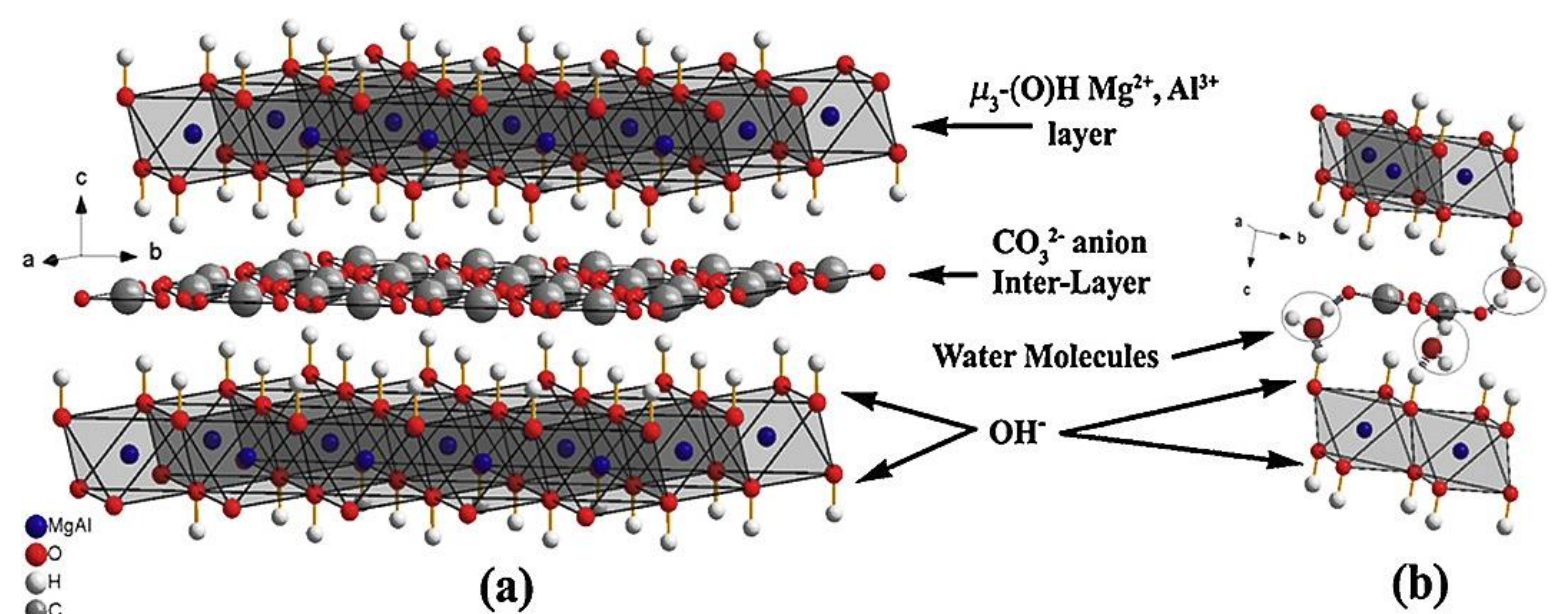

Fig. 7 Schematic representation of an LDH structure (a); detailed schematic view of some physisorbed water molecules within the layers (b) [80].

\subsection{Preparation and application of iron based LDHs}

Iron-based LDHs belong to the sjogrenite and pyroaurite groups. Their representatives are found in nature. Their structures were described first by Allmann and Taylor in the 1960s [5-7]. Originally, their syntheses played important part in the preparation of some catalyst precursors $[81,82]$, their use in other fields was rare. The 
reasons could be that compared to the most common aluminum-containing LDHs, the preparation of iron-based LDHs needs more basic conditions and they are more sensitive to humidity. Nowadays, the use of iron-based LDHs in other areas than catalysis, is gaining impetus, they are applied as component of lithium ion batteries in calcined form [83], adsorbents (lead [84], selenite [85], phosphate [86], pyrophosphate [87] and humate $[88,89]$ removal, mainly from water), the preparation of thin films [90,91], magnetic materials [92,93], etc.

Interestingly, iron may be used as the divalent as well as the trivalent component of LDH. Ruby et al. have done extensive work in this field [91,93-95]. They used several methods ( $p \mathrm{H}$-titration, Mössbauer spectroscopy, high-resolution X-ray powder diffraction) to describe the formation and the modifications in the structural properties of $\mathrm{Fe}$ (II)Fe(III)LDH and their modified varieties.

As far as alkaline earth-iron LDHs are concerned, the CaFe- $[96,97]$ and $\mathrm{MgFe}-$ LDHs [98] have been described, but there was no information if BaFe- and SrFe-LDHs exist.

Compounds containing oxygen, barium and iron ions have been known for long. In 1953, Scholder gave a recipe for their preparation [99], where the iron constituent of these meta- and ortoferrates was in the oxidation state of +4 . More than a decade later, a paper was published from the same laboratory [100] describing the synthesis of some double hydroxides (alkali and alkaline earth hydroxometalates), among them $\mathrm{Ba}(\mathrm{II}) / \mathrm{Fe}(\mathrm{III})$ hydroxides with $\mathrm{Ba}_{3}\left[\mathrm{Fe}(\mathrm{OH})_{6}\right]_{2}$ stoichiometric composition. For the synthesis, highly alkaline aqueous solution was needed containing $10 \mathrm{M}$ of the base $(\mathrm{NaOH})$. It has been stated that the XRD trace was satisfactory but the diffractogram itself was neither published nor further discussed. At significantly higher base concentrations ( 20 M) the formation of $\mathrm{Ba}_{2}\left[\mathrm{Fe}(\mathrm{OH})_{7}\right]^{\cdot} 1 / 2 \mathrm{H}_{2} \mathrm{O}$ was reported by the same authors [101]. The structures of these materials were not discussed, and no hints were made, if they thought that they might have prepared LDHs.

\subsection{Solid-state photoreactions}

Photoreactions occur when high-energy radiation, specifically visible or ultraviolet light, is absorbed by molecules and excites valence electrons to a higher energy state. Normally, this energy will dissipate in the form of heat and light given off by the excited 
molecules, but occasionally, it can be used to perform reactions normally unavailable to the molecules in the ground state. Molecules in these photoexcited states are open to many more photoreactions depending on their structure [102].

Intermolecular photoreactions performed in the solid state offer a greater degree of control over the product distributions than the corresponding reactions carried out in the liquid phase. In the liquid phase, the reactant molecules may adopt several different conformations and orientations relative to each other, therefore several reactions may occur at the same time, thus, selectivity loss may take place. In the solid state, however, possibilities for molecular as well as macroscopic motions are limited, therefore, one may have greater control on the outcome of the transformations. In the crystalline form the reactants must have specific orientation and proximity (roughly speaking) for the reaction to take place [103,104]. These transformations are called topotactic reactions. The proximity criterion may be met in a constrained environment, like in the interlayer space of an $\mathrm{LDH}$, then, there is even greater control on the possible transformations.

\subsubsection{Topotactic photodimerization in the solid state}

The $[2+2]$ photoinitiated cycloaddition is a powerful carbon-carbon bond forming reaction [105]. The problem of solid-state reactions is that, unless the orientation of the reactants in the crystal is known, the chemical and stereochemical outcome is highly unpredictable. Even if it is known and the photodimerization reaction proceeds, i.e., the olefinic double bonds are within the topotactic limit (i.e., the reacting functional groups should be close enough to each other - $4.2 \AA$ ) [103], for instance, for $E$-cinnamic acid, two photodimers $\alpha$-truxillic or $\beta$-truxinic acid will form [106-108] (Fig. 8).

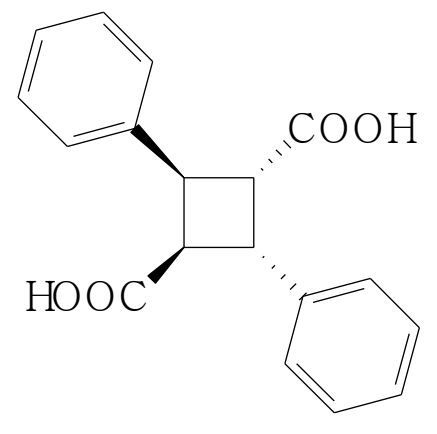

$\alpha$-truxillic acid

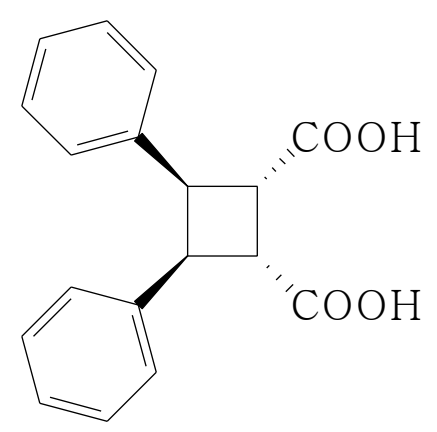

$\beta$-truxinic acid

Fig. 8 The two photodimers from $E$-cinnamic acid (E-2-phenylpropenoic acid). 
Both compounds are important, both have high anti-inflammatory activity [109]. Furthermore, $\alpha$-truxillic acid derivatives might provide a starting point for a natural product inspired synthesis program with the aim of improving existing peroxisome proliferator-activated receptor agonists [110]. Nevertheless, it would be desirable to drive the reaction towards that product which is needed at the moment.

\subsubsection{Topotactic photodimerization in the confined space of $L D H$}

There was some research activity in the chemistry community towards the more controlled photodimerization of cinnamic acid derivatives [111-115]. In order to achieve better selectivity, the confined environment of synthesized hydrotalcites were used with a variety of substituted cinnamate derivatives intercalated in the interlayer space. Both photodimerization and photoisomerization of cinnamate anions occurred within the gallery region [111]. It was observed that the relative amounts of isomerization and dimerization depended on the stoichiometry of the parent layered double hydroxide, i.e., on the density of charges, which is related to the relative quantity of the trivalent ion, the aluminum ion that is [114]. It was found that photodimerization tended to give overwhelmingly the $\beta$ dimer over the $\alpha$-dimer [112,113]. The selective formation of the $\beta$-dimer (head-to-head dimer) may be explained by the importance of intermolecular distances of two double bonds of adjacent carboxylates [113], which was $\sim 5.2 \AA$ and $\sim 7 \AA$ for the parallel and antiparallel arrangements, respectively (form the gallery height data a monolayer of the cinnamate anions was deduced). These distances are approximate and average ones. Even the shorter distance is above Smith's topotactic limit, nevertheless there was considerable photodimerization, i.e., significant amounts of the intercalated anions were close enough to each other for the reaction to occur. Obviously, the chance for the anions situated in antiparallel manner in the interlayer space to be within the limit is much slimmer, which is reflected in the minor amounts of the $\alpha$-dimer.

A computer simulation concerning the possible arrangements of cinnamate derivatives among the layers of hydrotalcites with varying $\mathrm{Mg}$ : $\mathrm{Al}$ ratio revealed that the intercalate may form monolayer, double layer with clearly separated layers of anions or interpenetrating double layer, and within the layer, the anions can be situated in various ways, e.g. orthogonally, tilted or parallel to the layer [115]. The observed arrangement may depend on various factors like the LDH (the constituent ions and the ratio of the di- to trivalent metal ions), the mode of intercalation (e.g. the choice of the solvent) and the structure of the cinnamate derivative and they all may influence the outcome of the 
photoinitiated topotactic [2+2] dimerization reaction. These factors have not been explored, leaving much room for research. 


\section{AIMS OF THE WORK}

At the start of this work, we were able to prepare a material containing $\mathrm{Ba}(\mathrm{II})$ and $\mathrm{Fe}(\mathrm{III})$ ions under hyperalkaline conditions (in the presence of $\mathrm{NaOH}$ over $10 \mathrm{M}$ concentration), which was proved to be of layered structure in spite of the significant difference in the ionic radii of the two ions $(0.149 \mathrm{~nm}$ for $\mathrm{Ba}(\mathrm{II})$ [116] and $0.069-0.079 \mathrm{~nm}$ for Fe(III) [117]). The accumulated knowledge briefly outlined above and this enlightening result initiated us to

1. explore the experimental conditions and finding the limits under which $\mathrm{Ba}(\mathrm{II}) \mathrm{Fe}(\mathrm{III}) \mathrm{LDH}$ are formed,

2. characterize this novel material with as many tools as it is possible,

3. extend the synthetic efforts for the other members of the alkaline earth ions keeping $\mathrm{Fe}(\mathrm{III})$ as the trivalent counterpart and to characterize them in as many ways as it is possible,

4. find the most efficient method for the synthesis of inorganic-organic hybrid materials where the host material is $\mathrm{Ca}(\mathrm{II}) \mathrm{Fe}(\mathrm{III})-\mathrm{LDH}$ and the guest anions are various acrylates,

5. characterize the organic-inorganic hybrids with all available methods,

6. explore the possibility of using the organic-inorganic hybrids as nanoreactors in $[2+2]$ topotactic cyclisation reactions. 


\section{EXPERIMENTAL PART}

\subsection{Materials}

All materials used for the syntheses of either the LDHs [calcium perchlorate $\left(\mathrm{Ca}\left(\mathrm{ClO}_{4}\right)_{2} \cdot 3 \mathrm{H}_{2} \mathrm{O}\right.$ (Fluka, p.a. grade), magnesium perchlorate $\left(\mathrm{Mg}\left(\mathrm{ClO}_{4}\right)_{2} \cdot 3 \mathrm{H}_{2} \mathrm{O}\right.$ (Fluka, p.a. grade), strontium perchlorate $\left(\mathrm{Sr}\left(\mathrm{ClO}_{4}\right)_{2} \cdot 3 \mathrm{H}_{2} \mathrm{O}\right.$, Fluka, p.a. grade), barium perchlorate $\left(\mathrm{Ba}\left(\mathrm{ClO}_{4}\right)_{2} \cdot 3 \mathrm{H}_{2} \mathrm{O}\right.$, Fluka, p.a. grade), iron perchlorate $\left(\mathrm{Fe}\left(\mathrm{ClO}_{4}\right)_{3} \cdot x \mathrm{H}_{2} \mathrm{O}\right.$ (Sigma-Aldrich, p.a. grade), perchloric acid (cc. $\mathrm{HClO}_{4}$ (ca. $30 \mathrm{~m} / \mathrm{m} \%$, Merck, p.a. grade), calcium chloride $\left(\mathrm{CaCl}_{2}\right.$, Molar Chemicals, puriss), magnesium chloride $\left(\mathrm{MgCl}_{2} \cdot 6 \mathrm{H}_{2} \mathrm{O}\right.$, Molar Chemicals, a.r.) iron chloride $\left(\mathrm{FeCl}_{3} \cdot 6 \mathrm{H}_{2} \mathrm{O}\right.$, Molar Chemicals, puriss special), hydrogen chloride $(\mathrm{HCl})$, sodium hydroxide ( $\mathrm{NaOH}, \mathrm{VWR}$, a.r. grade)] or the acrylate-intercalated LDHs [acrylate derivatives (Sigma Aldrich, p.a., see on page 20)] were used as received without any further purification. The concentrations of the iron-containing solutions were determined iodometrically. Millipore MilliQ water was used throughout the experiments.

\subsection{Preparation of concentrated $\mathrm{NaOH}[\mathrm{c} \sim 20 \mathrm{M}]$ solution}

Concentrated $\mathrm{NaOH}(\sim 20 \mathrm{M})$ stock solution was prepared from Millipore MilliQ water and a.r. grade solid $\mathrm{NaOH}$. Its carbonate content was minimized. Where relevant, the Millipore water was rendered free of $\mathrm{CO}_{2}$ by boiling while purging through it high purity nitrogen for at least $20 \mathrm{~min}$. After preparation, the base solutions were stored in airtight plastic or Pyrex glass. It is worth noting that Pyrex (as opposed to soda glass) shows very little reactivity towards alkaline solutions at ambient temperature. No visible signs of deterioration were observed for highly concentrated base solutions stored in Pyrex vessels at ambient temperature over long periods [118]. The density of the solution was determined by a picnometer. $\mathrm{NaOH}$ solutions of various concentrations were made from this stock solution just before the synthesis.

\subsection{LDH syntheses with concentrated $\mathrm{NaOH}[\sim 10-20 \mathrm{M}]$ solution using the perchlorate salts}

All samples were prepared by the co-precipitation method. At higher $\mathrm{NaOH}$ concentrations $\left([\mathrm{NaOH}]_{\mathrm{T}} \geq 10 \mathrm{M}\right), 20 \mathrm{~cm}^{3}$ of the aqueous solution of the divalent metal 
salt $\left[\mathrm{Sr}\left(\mathrm{ClO}_{4}\right)_{2}, \mathrm{Ba}\left(\mathrm{ClO}_{4}\right)_{2}, \mathrm{Ca}\left(\mathrm{ClO}_{4}\right)_{2}\right.$ or $\left.\mathrm{Mg}\left(\mathrm{ClO}_{4}\right)_{2}\right]$ and that of the iron salt $\left[\mathrm{Fe}\left(\mathrm{ClO}_{4}\right)_{3}\right]$, as the trivalent one, were added dropwise to $200 \mathrm{~cm}^{3}$ of hot, vigorously stirred and $\mathrm{N}_{2^{-}}$ blanketed $\mathrm{NaOH}$ solution using a home-made reactor (Fig. 9/a). Here, the relative decrease of the $\left[\mathrm{OH}^{-}\right]$during the syntheses was less than $10 \%$, therefore, the $p \mathrm{H}$ of the solution can be considered as constant. The molar ratios of the divalent to the trivalent metal ions were varied as $2: 1,3: 1$ or $4: 1$ by changing the concentrations of the solutions of the divalent metal ions between $0.4 \mathrm{M}$ and $0.8 \mathrm{M}$. The concentration of the iron-containing solution was constant $(0.2 \mathrm{M})$. The concentration of perchloric acid used as an auxiliary agent was $0.1 \mathrm{M}$. The resulting mixture was rapidly filtered until air dry in a practically $\mathrm{CO}_{2}$-free atmosphere, with the aid of a caustic resistant vacuum filter unit (Nalgene) equipped with an appropriate membrane (Versapor, $0.45 \mu \mathrm{m}$ ). The solid material was washed with small amounts of pure and hot $\mathrm{NaOH}$ solution with the same concentration. The moisture sensitive crystals were kept in a desiccator over dry $\mathrm{SiO}_{2}$ at ambient temperature.

\section{4. $\mathrm{LDH}$ syntheses with $\mathrm{NaOH}[\mathrm{c}=3-5 \mathrm{M}]$ solutions using the chloride salts}

All samples were prepared by the co-precipitation method. In a typical synthesis of $\mathrm{Ca}(\mathrm{II}) / \mathrm{Mg}(\mathrm{II}) \mathrm{Fe}(\mathrm{III})-\mathrm{LDH}, \mathrm{NaOH}$ solution $\left([\mathrm{NaOH}]_{\mathrm{T}}=3-5 \mathrm{M}\right)$ was added dropwise to the vigorously stirred and, in a set of experiments, $\mathrm{N}_{2}$-blanketed solution containing the salts of the divalent metal ions $\left(\mathrm{CaCl}_{2}\right.$ or $\left.\mathrm{MgCl}_{2}\right)$ and the trivalent metal ion $\left(\mathrm{FeCl}_{3}\right)$. Hydrochloric acid $(\mathrm{HCl})$ was used to set the $p \mathrm{H}$ to 2. $3 \mathrm{M} \mathrm{NaOH}$ solutions were used by the end of the syntheses when the $\left[\mathrm{OH}^{-}\right]$was set to $0.1 \mathrm{M}$ (method $A$ and $B$ ), $1.875 \mathrm{M}$ $(\operatorname{method} C)$ or $2.55 \mathrm{M}(\operatorname{method} D)$. When the final $\left[\mathrm{OH}^{-}\right]$was planned to be $5 \mathrm{M}$, then the 5 $\mathrm{M} \mathrm{NaOH}$ solution was used (method $E$ ). The molar ratios of divalent to trivalent metals were systematically varied between $2: 1,3: 1,4: 1,5: 1$, and $6: 1$. The concentration of the iron solution was $0.1 \mathrm{M}$ and that of hydrochloric acid was $0.01 \mathrm{M}$. The after-syntheses treatment was the same as described in the preceding subchapter.

\subsection{Preparation of the organic-inorganic nanocomposites}

\subsection{1. "Ex situ" hydrothermal process (the rehydration-dehydration method)}

The washed and dried LDH powder was hydrothermally treated in a Thermolyne 21100 tubular furnace for 6 hours at $\mathrm{T}=393 \mathrm{~K}$. The hydrothermally treated LDH powder was added to the aqueous-ethanolic solutions (water:ethanol: $\mathrm{NaOH}=5: 1: 1$ ) of various 
acrylate derivatives (see Table 1), and stirred for 7 days at $353 \mathrm{~K}$ under inert atmosphere. The resulting suspensions were filtered and washed three times and then dried in a desiccator over dry $\mathrm{SiO}_{2}$.

\subsection{2. "In situ" co-precipitation method}

First, basic solution of, e.g. Na-cinnamate was prepared. Acidic mixture of $\mathrm{CaCl}_{2}$ and $\mathrm{FeCl}_{3}$ in 3:1 molar ratio was also prepared. The acidic metal salt solution was added dropwise to the basic cinnamate solution using the home-made reactor (Fig. 9/b) under continuous stirring maintained for further 48 hours at $\mathrm{T}=353 \mathrm{~K}$ after the mixing. The $p \mathrm{H}$ of the solution was adjusted with $[\mathrm{NaOH}]_{\mathrm{T}}=3 \mathrm{M}$ to 13 at the end of reaction, when the products were precipitated. The solution was filtered, washed and dried as described above.

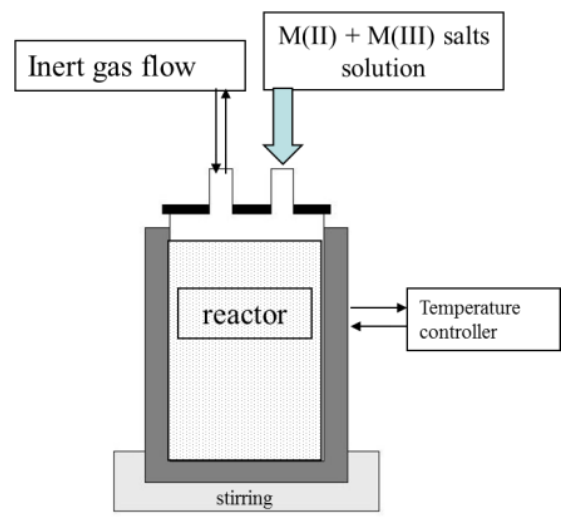

(a)

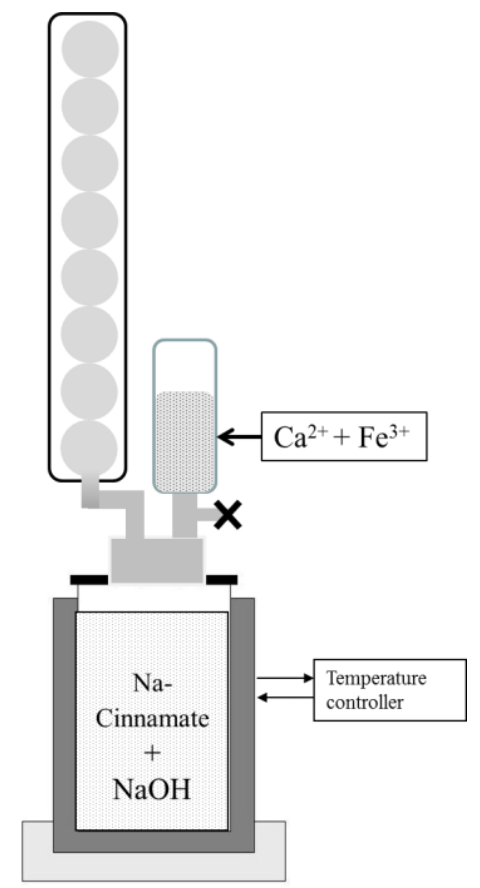

(b)

Fig. 9 Scheme of the reactors for the preparation of LDHs: (a) simple; (b) equipped with a reflux condenser. 
Table 1 The intercalated acrylate derivatives.

\begin{tabular}{|c|c|c|}
\hline The intercalated anion & formula & molecular structure \\
\hline$E$-3-phenylpropenoate & $\mathrm{C}_{9} \mathrm{H}_{7} \mathrm{O}_{2}^{-}$ & \\
\hline$E-3\left(4^{\prime}\right.$-nitrophenyl)propenoate & $\mathrm{C}_{9} \mathrm{H}_{6} \mathrm{NO}_{4}^{-}$ & \\
\hline$E-3\left(2^{\prime}\right.$-thienyl)propenoate & $\mathrm{C}_{7} \mathrm{H}_{5} \mathrm{O}_{2} \mathrm{~S}^{-}$ & \\
\hline$E$-2,3-dimethylpropenoate & $\mathrm{C}_{5} \mathrm{H}_{7} \mathrm{O}_{2}^{-}$ & $\mathrm{CH}_{3}$ \\
\hline $\begin{array}{c}E-3\left(4^{\prime}-\text { chlorobenzoyl)pro- }\right. \\
\text { penoate }\end{array}$ & $\mathrm{C}_{10} \mathrm{H}_{6} \mathrm{ClO}_{3}^{-}$ & \\
\hline $\begin{array}{c}E-3\left(2^{\prime}, 5^{\prime}-\text { difluorophenyl }\right) \text { pro- } \\
\text { penoate }\end{array}$ & $\mathrm{C}_{9} \mathrm{H}_{5} \mathrm{~F}_{2} \mathrm{O}_{2}^{-}$ & \\
\hline $\begin{array}{c}E \text {-2-cyano-3(4'-hydroxy- } \\
\text { phenyl)propenoate }\end{array}$ & $\mathrm{C}_{10} \mathrm{H}_{6} \mathrm{NO}_{3}^{-}$ & \\
\hline$E$-3(4'-imidazolyl)propenoate & $\mathrm{C}_{6} \mathrm{H}_{5} \mathrm{~N}_{2} \mathrm{O}_{2}^{-}$ & \\
\hline
\end{tabular}




\section{6. [2+2] topotactic photodimerization}

The reactions were performed in the solid state with the intercalated compounds as well as the pristine guest anions. $2 \mathrm{mg}$ samples were diluted with $200 \mathrm{mg} \mathrm{KBr}$, and were pelletized. These pellets were irradiated using a xenon light source (MAX-302, Asahi Spectra USA, $300 \mathrm{~W}$ ) working in the 220-400 nm wavelength range for 5 to 90 minutes. The distance between the light source and the sample was held constant $(25 \mathrm{~cm})$. The initiated photochemical reactions were monitored by FT-IR spectroscopy.

\subsection{Characterization methods}

\subsubsection{Thermal analytical measurements}

Thermal analytical measurements were performed using a Setaram Labsys derivatograph (France) working under $\mathrm{N}_{2}$ flow at $2{ }^{\circ} \mathrm{C} \min ^{-1}$ heating rate. Both the weight loss vs. temperature (thermogravimetric $-\mathrm{TG}$ ) and the differential weight loss $v s$. temperature (differential thermogravimetric - DTG) curves were recorded. Approximately $20 \mathrm{mg}$ sample (measured accurately into a ceramic crucible sample holder) was applied in each experiment. Measurements were started right after taking the samples out of the desiccators.

\subsubsection{X-ray diffractometry}

Powder X-ray diffraction (XRD) patterns of the air-dried and heat-treated solid samples were registered in the $2 \Theta=3-70^{\circ}$ range on Philips PW1710 instrument, using $\mathrm{CuK \alpha}(\lambda=1.5418 \AA)$ radiation. Reflection positions were determined via fitting a Gaussian function. They were found to be reproducible within $0.05^{\circ}$, therefore the uncertainty of the basal spacing was estimated to be $\pm 0.1 \AA$. Grinding the moisture sensitive materials had to be done fast and very carefully. The samples were pasted onto the quartz sample holder.

\subsubsection{Microscopic techniques}

The morphologies of the substances obtained were studied using a Hitachi S-4700 scanning electron microscope (SEM) at various magnifications (1,000-90,000). Acceleration voltage was set to $10 \mathrm{kV}$. The samples were ground before fixing them on a double-sided adhesive carbon tape. They were coated with gold in order to obtain images 
with more contrast, using a sputter coater (Quorum Technologies SC7620). The thickness of the gold layer was few nanometers.

The relative quantities of the di- and trivalent inorganic ions and those of the organic anions in the solid samples were determined with a Röntec QX2 energy dispersive $\mathrm{X}$-ray fluorescence (EDX) spectrometer coupled to a microscope. Because of the carbon content of our samples, fixing the samples needed a method different from the previous one. $C a .1 \mathrm{~m} / \mathrm{m} \%$ concentrated ethanolic, or acetonic suspension of the sample was dropped onto a fixed silicon mirror (Fig. 10) and was heat treated at $333 \mathrm{~K}$ for 15 minutes to evaporate the solvent before measurement. The SEM-EDX coupled system provided with the elemental map.

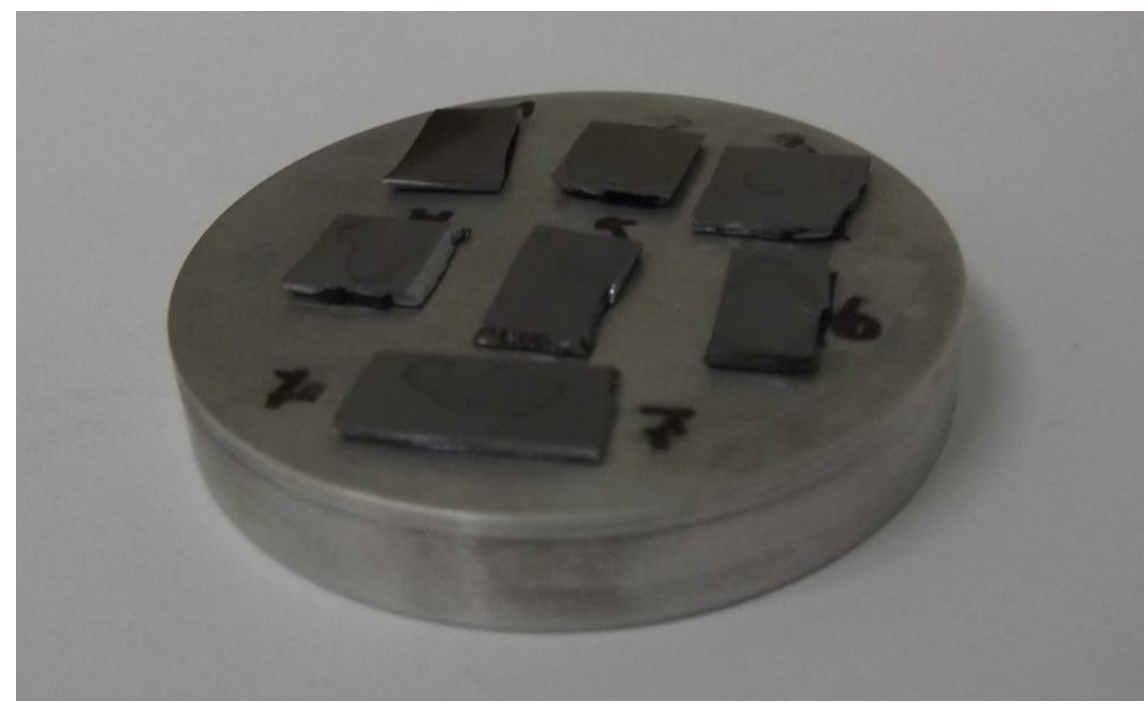

Fig. 10 The sample holder for the EDX measurements.

\subsubsection{Mössbauer spectroscopy}

${ }^{57} \mathrm{Fe}$ Mössbauer spectra of the samples were recorded with conventional Mössbauer spectrometers (Wissel and Ranger) in transmission geometry at the temperature of $78 \mathrm{~K}$. Isomer shifts are given relative to $\alpha$-iron. $\mathrm{A}{ }^{57} \mathrm{Co} / \mathrm{Rh}$ radiation source of $3 \times 10^{9} \mathrm{~Bq}$ activity was used. The Mössbauer spectra were analyzed by least-squares fitting of the Lorentzian lines with the help of the MOSSWINN program [119].

\subsubsection{XAS measurements}

The X-ray absorption spectra (XAS) were measured at beamline I811 at the MaxLab facility, Lund, Sweden. The station is based on a superconductive multipolar 
wiggler radiation source connected to the $1.5 \mathrm{GeV}$ MAX II storage ring. X-ray radiation in the $2.4-12 \mathrm{keV}$ energy range can be obtained from this system. The maximum flux on the sample at $9 \mathrm{keV}$ was $5 \times 10^{11}$ on a $0.5 \mathrm{~mm} \times 0.5 \mathrm{~mm}$ surface area.

Measurements were performed at the $\mathrm{Fe}-\mathrm{K}$-edge $(7112 \mathrm{eV})$ in the fluorescent mode. The sample holder was made of Teflon and its window was Kapton (polyimide) ribbon. Due to the high iron content of the sample, it had to be diluted with boron nitride. All manipulations were done in a dry box. The analysis of the near-edge spectrum was performed with the help of the EXAFSPAK [120] and the FEFF [121,122] packages allowing us to obtain quantitative data on the local coordination environment of the $\mathrm{Fe}(\mathrm{III})$ ion.

\subsubsection{FT-IR spectroscopy}

The success of intercalation and the effects of UV radiation were studied by FT-IR spectroscopy. For structural infrared investigations $1 \mathrm{mg}$ sample powder was pressed into a $200 \mathrm{mg} \mathrm{KBr}$ pellet. Spectra were taken on a Bruker 66V FT-IR spectrometer (unapodized resolution $0.25 \mathrm{~cm}^{-1}$ ) and coupled to a Bruker Hyperion 3000 IR microscope. 256 scans were collected for a spectrum. The spectra were baseline corrected, smoothed if it was necessary and the spectrum of the pristine LDH was subtracted. All these operations were performed with the OPUS (Bruker Optics Ltd's product) program package.

\subsubsection{Molecular modeling}

The geometric parameters of the intercalated carboxylate ion were determined after performing full geometry optimization to gradient norm 0.1 with the PM3 [123,124] semiempirical quantum chemical method included in the Hyperchem 8.0 molecular modeling package [125]. 


\section{RESULTS AND DISCUSSION}

In the field of LDHs, there are two main research areas. The main goal of the first one is to obtain novel materials having unique composition, chemical and physical properties. The novel materials may be new LDHs or composites of already known LDHs with organic or inorganic anions of various types. Beside syntheses this area includes the many-sided characterization of the substances obtained. The other area deals with the applications of the LDHs and LDH composites. Since there are so many application possibilities (e.g., catalysis, use as fire retardants, targeted drug release, enantio- and diastereoselective syntheses just to mention a few) that this field branches to several subareas.

The main goal of the experimental work was to achieve novel results in both areas. Therefore, this section of the dissertation is divided along these two lines. In the first part, I focus on the preparation and characterization of novel LDHs and organic-inorganic LDH composites, while in the second one I show an example when the organic-inorganic composites were applied as nanoreactors in $[2+2]$ topotactic cyclisation reactions.

\subsection{Preparation and characterization of alkaline earth metal ion/Fe(III) double hydroxides}

The title of this subsection does not contain the word "layered". Although it is known that $\mathrm{Mg}(\mathrm{II}) \mathrm{Fe}$ (III) and $\mathrm{Ca}(\mathrm{II}) \mathrm{Fe}(\mathrm{III})$ double hydroxides have layered structures, it has been stated that even though $\mathrm{Ba}(\mathrm{II}) \mathrm{Fe}(\mathrm{III})$ double hydroxide can readily be synthesized [99-101], it does not have layered structure and almost nothing is known about the synthesis possibilities and structural features of a would-be $\mathrm{Sr}(\mathrm{II}) \mathrm{Fe}(\mathrm{III})$ double hydroxide.

According to received knowledge, LDHs can only form if the ionic radii of the two metal ions are similar [1]. Since those of $\mathrm{Ba}(\mathrm{II})$ and $\mathrm{Fe}(\mathrm{III})$ widely differ (for octahedral coordination the ionic radii of $\mathrm{Ba}(\mathrm{II})$ and $\mathrm{Fe}$ (III) are $1.49 \AA$ [116] and 0.69 (in low-spin complexes) or $0.79 \AA$ (in high-spin complexes) [117], respectively) one may not be surprised that researchers did not seek for conditions under which $\mathrm{Ba}$ (II)Fe(III) double hydroxide assumed a layered structure. However, I am going to show in the followings that under extremely alkaline $(\mathrm{NaOH}$ concentration is $\geq 10 \mathrm{M}$ - "hyperalkaline" in further discussion) conditions the above statement is invalidated, $\mathrm{Ba}(\mathrm{II}) \mathrm{Fe}(\mathrm{III}) \mathrm{LDHs}$ do form within an appreciably wide range of composition. 


\subsubsection{Syntheses and characterization of Ba(II)Fe(III) layered(?) double hydroxide}

Many samples have been prepared with the co-precipitation technique varying the $\mathrm{Ba}$ (II) to $\mathrm{Fe}(\mathrm{III})$ ratios $(2: 1,3: 1,4: 1)$ and the $\mathrm{NaOH}$ concentration $(2 \mathrm{M}, 5 \mathrm{M}, 10 \mathrm{M}, 20 \mathrm{M})$.

At every $\mathrm{Ba}(\mathrm{II}): \mathrm{Fe}(\mathrm{III})$ ratio white or pale yellow precipitate appeared instantaneously at $[\mathrm{NaOH}]_{\mathrm{T}} \geq 10 \mathrm{M}$ showing that the otherwise expected formation of $\mathrm{Fe}(\mathrm{III})$ oxyhydroxides $(\mathrm{FeOOH})$ did not take place. At lower concentrations of the base (2 $\mathrm{M}$ and $5 \mathrm{M}$ ) formation of $\mathrm{FeOOH}$ was observed.

The X-ray diffractograms of the filtered and air-dried fresh or aged (1 year at room temperature in a desiccator over $\left.\mathrm{SiO}_{2}\right)$ products $(\mathrm{BaFe}-\mathrm{LDH}-\mathrm{XX}$, where $\mathrm{XX}$ represents $[\mathrm{NaOH}]_{\mathrm{T}}$ in $\mathrm{M}$ and at $\mathrm{Ba}(\mathrm{II}): \mathrm{Fe}(\mathrm{III})=3: 1$ ) were taken and are shown in Fig. 11. The XRD patterns of the white or pale yellow products obtained for BaFe-LDH-10 and BaFe-LDH20 display the characteristic features of an $\mathrm{LDH}$, while the products obtained at 2 and $5 \mathrm{M}$ base concentrations did not. The typical reflections are indicated in the figure. The first reflection, the (003) that is, the most important here and also in the whole LDH literature, since its position is used for calculating the basal spacing $(d)$, which is a key parameter. It includes the distance between two neighboring layers and the thickness of one layer. For calculating the interlayer distance one needs to know the thickness of a layer. Unfortunately, it is not known for LDHs except for hydrotalcite (MgAl-LDH). It is $4.6 \AA$ [126] and this is the value I am going to use when interlayer distance data are needed.

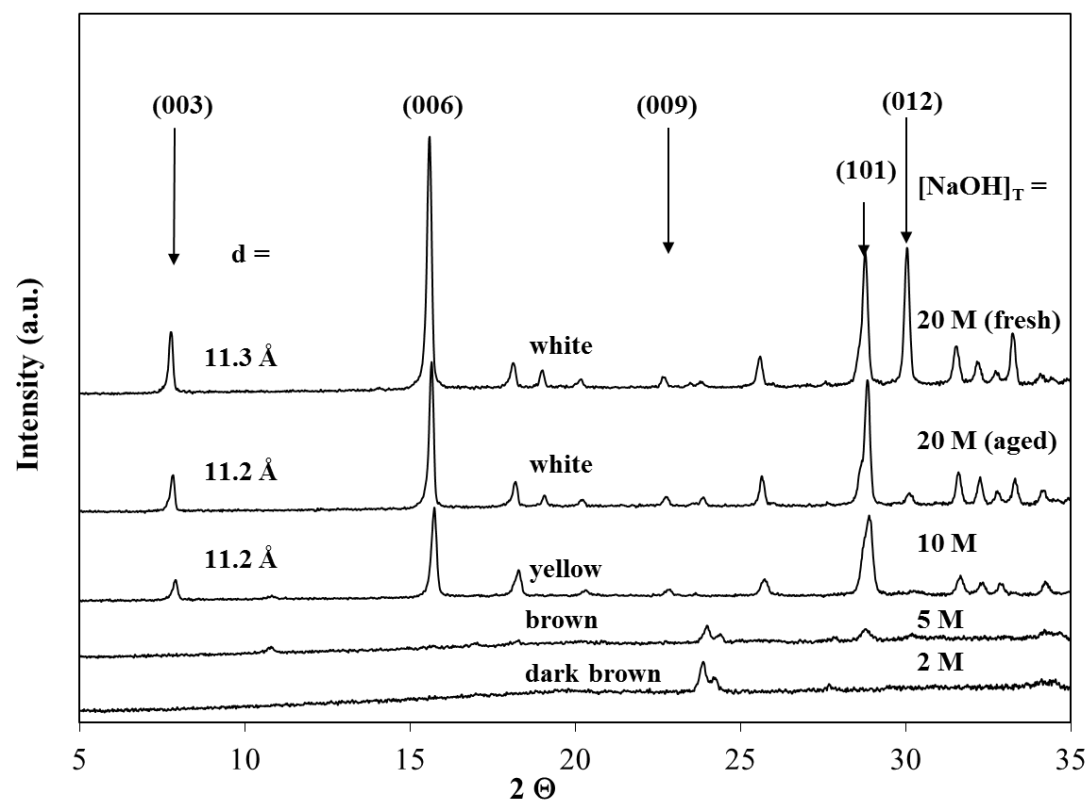

Fig. 11 XRD patterns of the freshly prepared, aged (1 year at room temperature in a desiccator over $\mathrm{SiO}_{2}$ ) and air-dried $\mathrm{Ba}(\mathrm{II}) \mathrm{Fe}(\mathrm{III})$ precipitates obtained at various $[\mathrm{NaOH}]_{\mathrm{T}}-\mathrm{S}$ at $\mathrm{Ba}(\mathrm{II}): \mathrm{Fe}(\mathrm{III})=3: 1$. The color of the materials and the basal spacing for the LDHs obtained from solutions with $[\mathrm{NaOH}]_{\mathrm{T}} \geq 10 \mathrm{M}$ are also shown. 
Thus, LDH formation in this system requires sufficiently high $[\mathrm{NaOH}]_{\mathrm{T}}$. At these very high base concentrations the solubility of $\mathrm{Ba}(\mathrm{OH})_{2}$ is relatively low. In the absence of $\mathrm{Ba}(\mathrm{II})$, under these conditions the Fe(III) ions are precipitated in the form of the Na-salts of the $\mathrm{Fe}(\mathrm{III})-$ hydroxo complexes consisting of $\left[\mathrm{Fe}(\mathrm{OH})_{6}\right]^{3-}$ structural units [118].

Calculated from the position of the 003 reflection, the basal spacings of our LDHs varied between 11.2 and $11.4 \AA$. After aging no significant decrease was seen, i.e., dehydration either did not occur or its effect on basal spacing was not significant. The basal spacing of $\mathrm{Ba}(\mathrm{II}) \mathrm{Fe}(\mathrm{III})-\mathrm{LDH}-10$ was somewhat smaller than that obtained for $\mathrm{Ba}(\mathrm{II}) \mathrm{Fe}(\mathrm{III})-\mathrm{LDH}-20$.

Upon changing the $\mathrm{Ba}(\mathrm{II})$ to $\mathrm{Fe}(\mathrm{III})$ ratio the $\mathrm{XRD}$ patterns remained similar (Fig. 12), and no systematic variation was seen in the $d(003)$ basal spacing (11.1-11.4 $\AA$ ).

It is unusual, but sometimes observed [127] that the intensity of the (003) reflection was lower than that of the (006). A possible reason may be the substantial difference in the radii of the metal ions indicating that we are at the edge of conditions where LDH formation is feasible. Nevertheless, in spite of low intensities the (003) reflections are clearly visible.

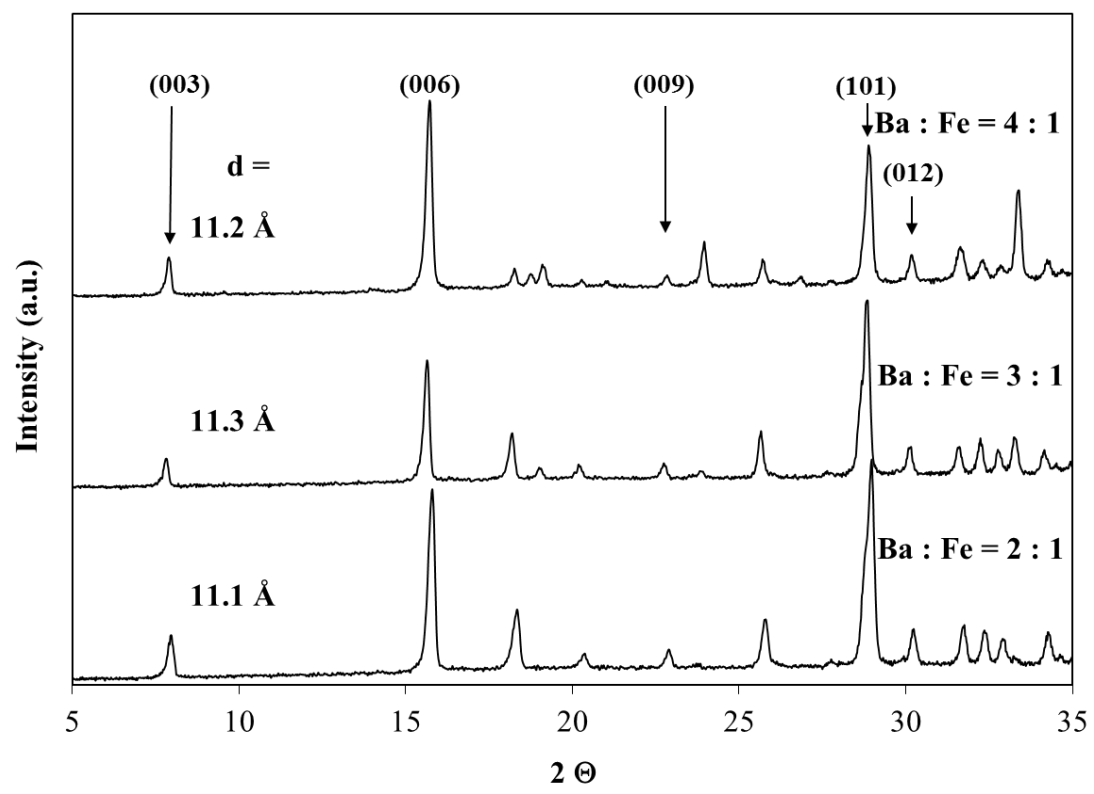

Fig. 12 XRD patterns of the freshly prepared and air-dried Ba(II)Fe(III)-LDH-20 with varying $\mathrm{Ba}(\mathrm{II})$ to $\mathrm{Fe}(\mathrm{III})$ ratios. The ratios and the basal spacing are indicated.

The thermal behavior of our substances was investigated in two ways: first, by thermogravimetry as usual, and second, via heat-treating the freshly prepared air-dried samples at various temperatures for an hour. These temperatures were chosen according to 
the TG and DTG curves. The heat-treated samples were subjected to XRD measurements and their XAS spectra were also registered (spectra and their discussion are included in chapter 5.1.2.).

TG and DTG traces indicated three dehydration steps (Fig. 13), just as it is expected for LDHs [128]. In the $50-120^{\circ} \mathrm{C}$ region water physically adsorbed on the outer surface of the particles was removed. In the $140-180^{\circ} \mathrm{C}$ region part of the interlayer water was desorbed without significant changes in the basal spacing. Above this temperature structural dehydration took place decreasing the basal spacing, and finally leading to the collapse of the layered structure.

In a second series of experiments, samples were heated to a given temperature with the same heating rate. In Fig. 14 XRD patterns corresponding to such steps are seen with $\mathrm{Ba}(\mathrm{II})_{3} \mathrm{Fe}(\mathrm{III})-\mathrm{LDH}-10$ as the example.

The XRD patterns showed close correspondence to the TG and DTG curves. The basal spacing only slightly decreased on samples treated at room temperature up to $180{ }^{\circ} \mathrm{C}$, however, the ones treated at $200{ }^{\circ} \mathrm{C}$ and above the (003) reflection almost completely disappeared.

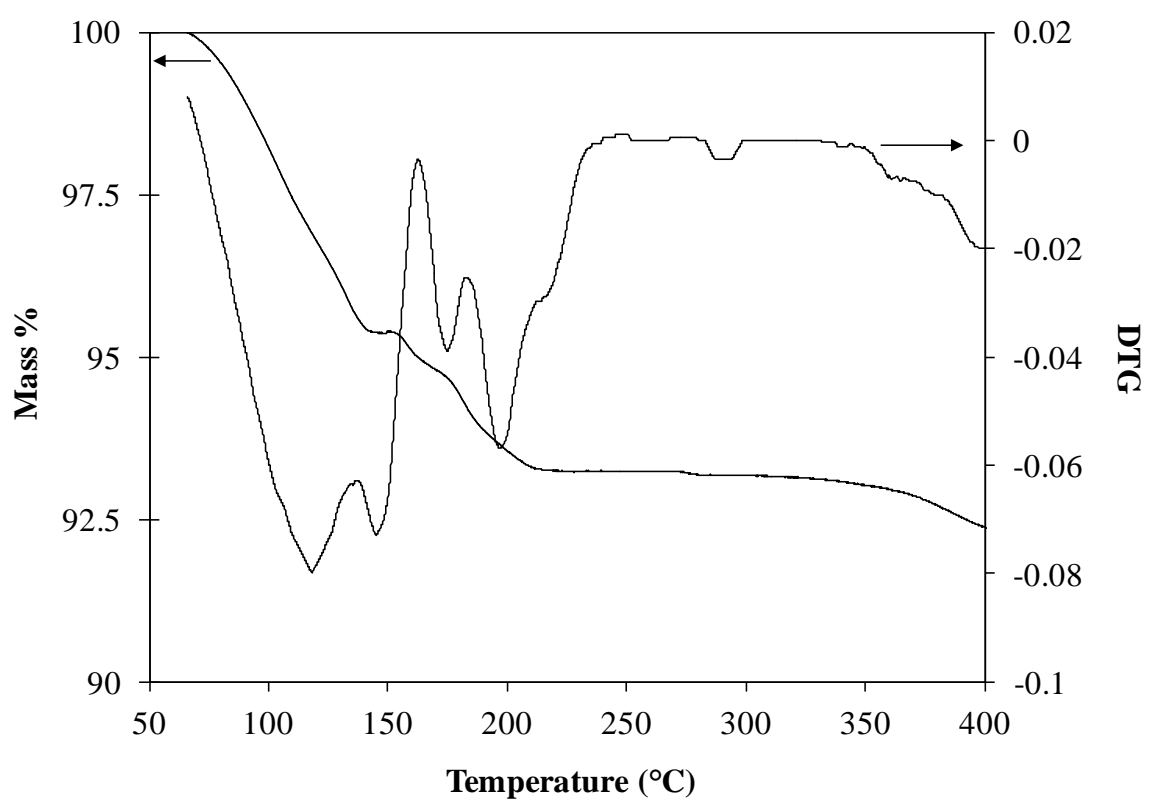

Fig. $13 \mathrm{TG}$ and DTG curves for $\mathrm{Ba}(\mathrm{II})_{3} \mathrm{Fe}(\mathrm{III})-\mathrm{LDH}-20$ indicating the three major dehydration steps. 


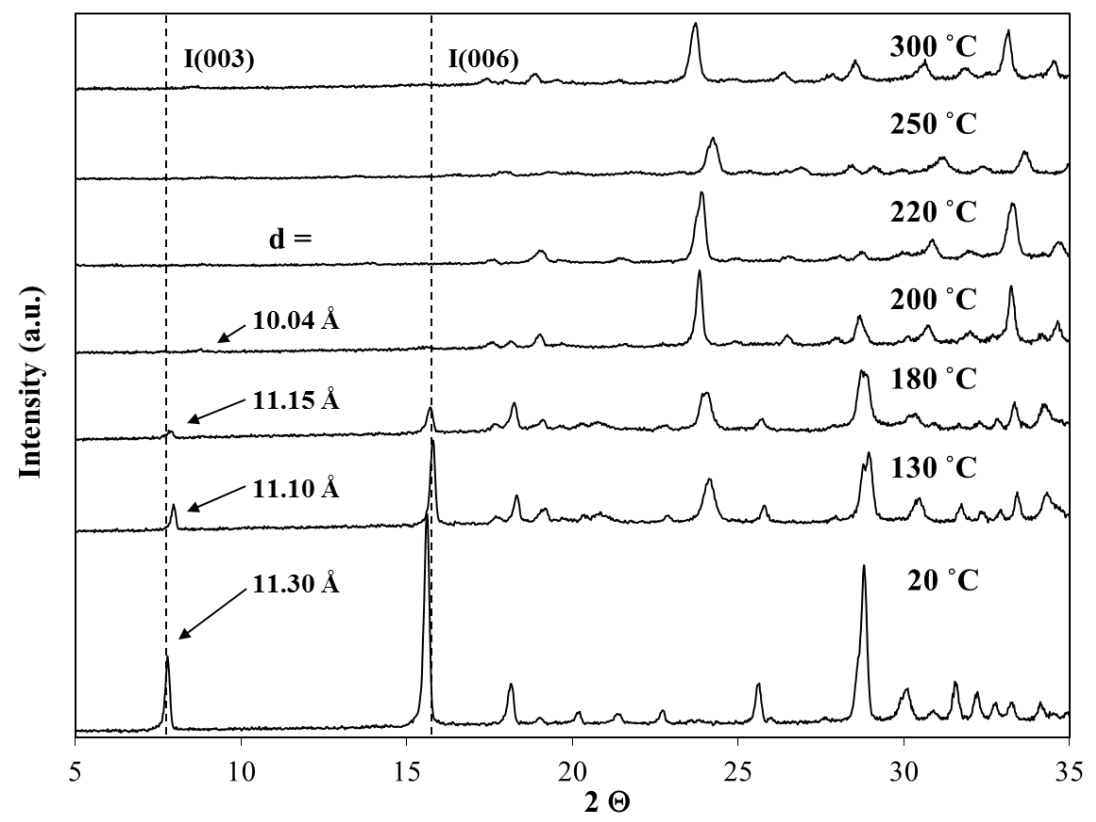

Fig. 14 XRD patterns corresponding to calcination of $\mathrm{Ba}(\mathrm{II})_{3} \mathrm{Fe}(\mathrm{III})-\mathrm{LDH}-10$ at different temperatures. The basal spacing values are also indicated.

SEM images of the $\mathrm{Ba}(\mathrm{II})_{3} \mathrm{Fe}(\mathrm{III})-\mathrm{LDH}$ sample show lamellar structure (Fig. 15). Here, the atomic level arrangement is reflected in the morphology. This may be considered good luck, because it is not necessarily always the case.

No signs of other crystalline material with any other structural feature than the layered structure are seen in the images.

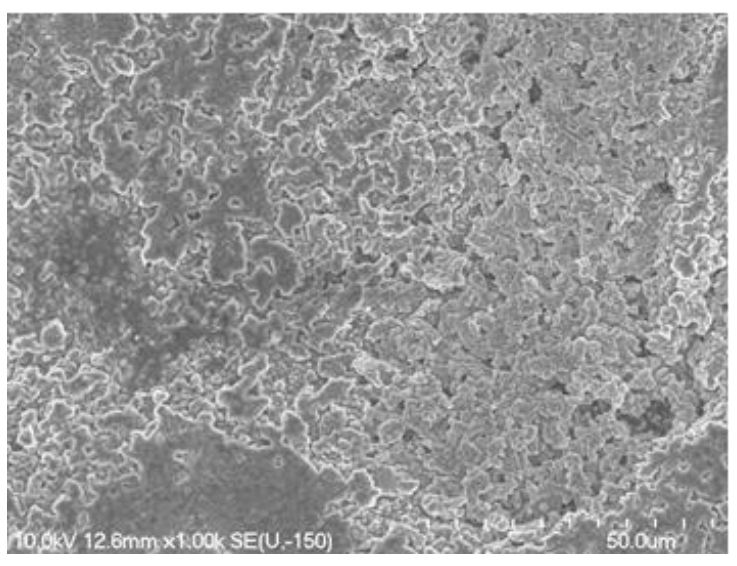

(a)

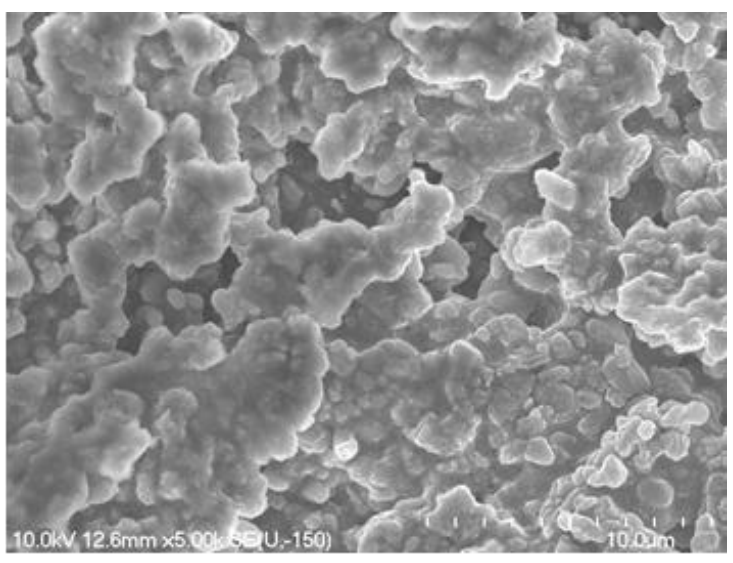

(b)

(continued on the following page) 


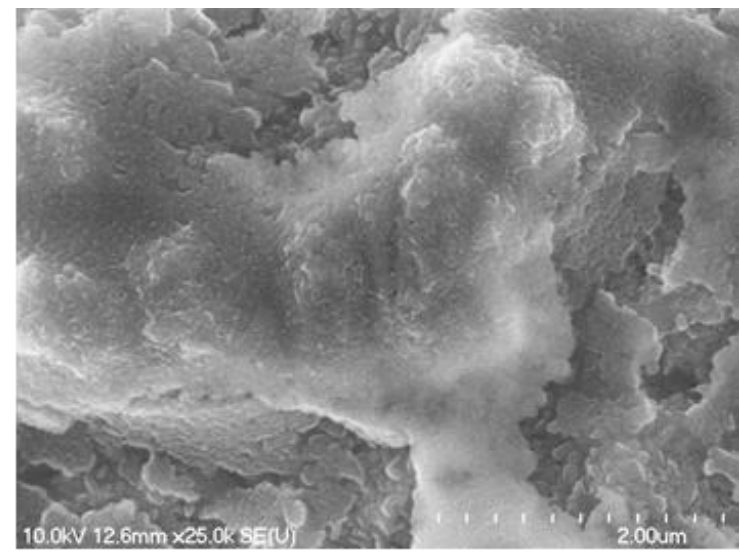

(c)

Fig. 15 SEM images of $\mathrm{Ba}(\mathrm{II})_{3} \mathrm{Fe}(\mathrm{III})-\mathrm{LDH}$ precipitated with $20 \mathrm{M} \mathrm{NaOH}$ at magnifycations of (a) 1,000, (b) 5,000 and (c) 25,000.

The elemental distribution is displayed in Fig. 16. These measurements were performed on two different places of the same sample, and the average concentration of barium and iron were 6.9 at $\%$ and 2.4 at\%, respectively. This is a 2.88 ratio of $\mathrm{Ba}$ to $\mathrm{Fe}$, close enough to the initial 3:1 $\mathrm{M}$ ratio of the salts used during the synthesis. Given that EDX can be considered as semi-quantitative analytical technique and $\mathrm{Ba}(\mathrm{OH})_{2}$ has some (limited) solubility in a $\sim 20 \mathrm{M} \mathrm{NaOH}$ solution, it can be concluded that the initial molar ratio in the salt solution is close to that in the solid material.

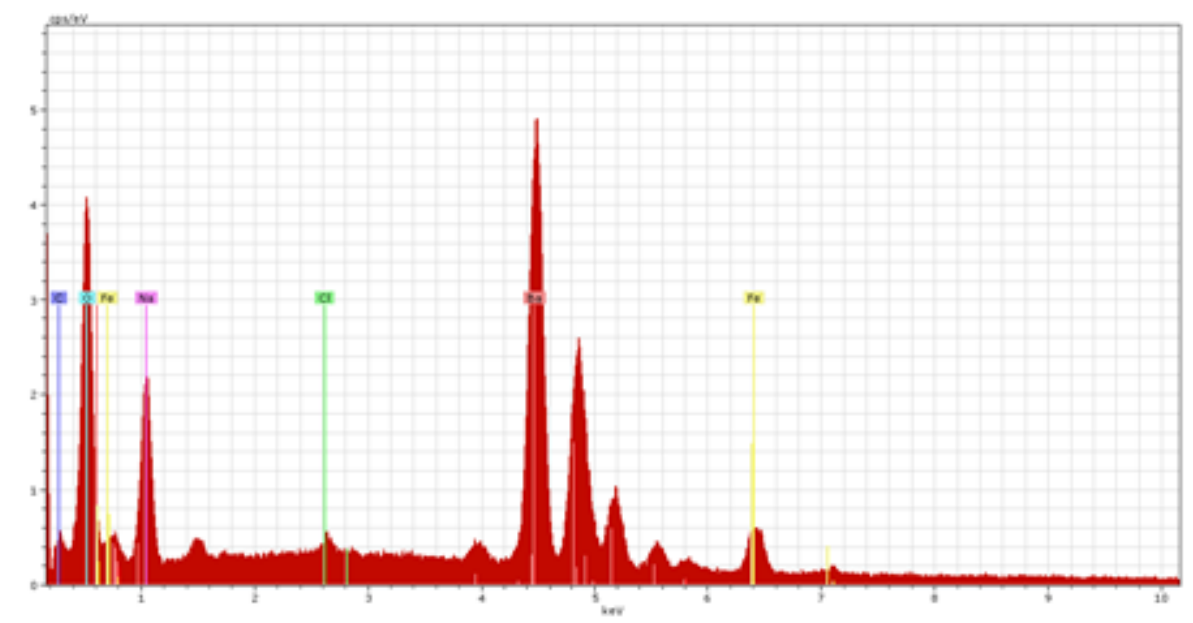

Fig. $16 \mathrm{EDX}$ spectrum of $\mathrm{Ba}(\mathrm{II})_{3} \mathrm{Fe}(\mathrm{III})-\mathrm{LDH}$ precipitated with $20 \mathrm{M} \mathrm{NaOH}$. 

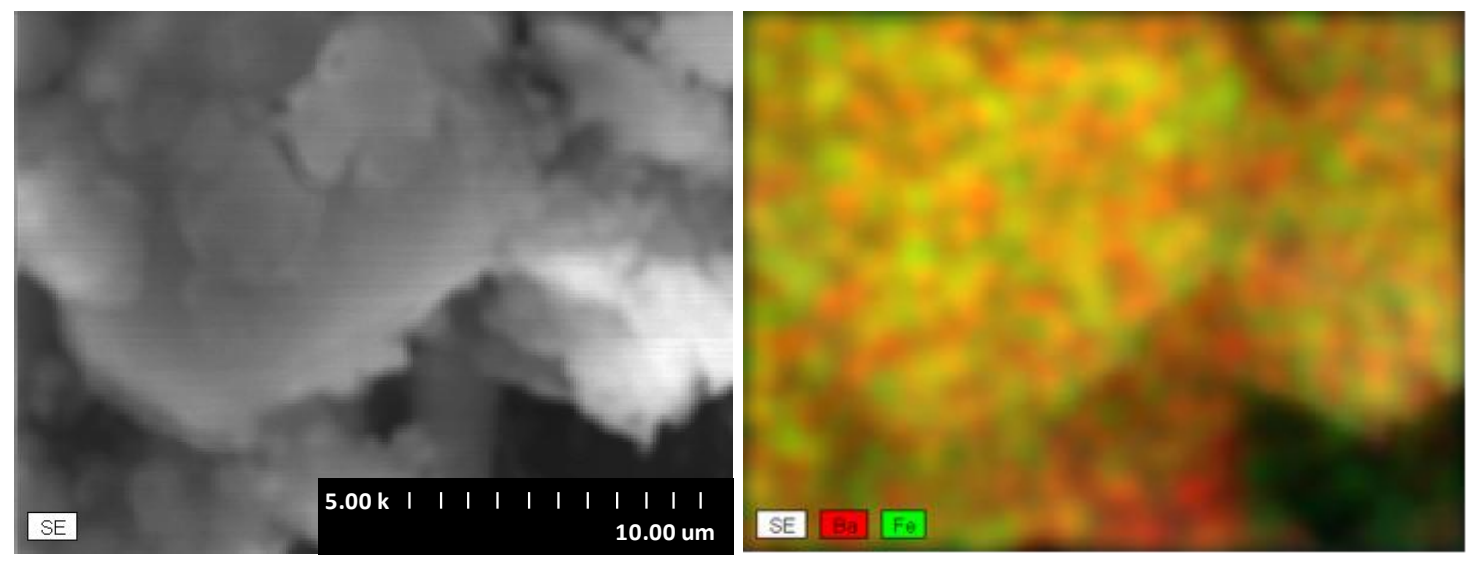

Fig. 17 Elemental map of $\mathrm{Ba}(\mathrm{II})_{3} \mathrm{Fe}(\mathrm{III})-\mathrm{LDH}$ precipitated with $20 \mathrm{M} \mathrm{NaOH}$ on the sample with magnification of 5,000 .

The elemental map, constructed on the sample with a magnification of 5,000 (Fig. 17), revealed a close to even distribution of the $\mathrm{Ba}(\mathrm{II})$ and the $\mathrm{Fe}(\mathrm{III})$ ions, convincingly showing that no segregation of the monoionic hydroxides/oxides occurred during the synthesis, i.e., double hydroxide was formed, indeed.

\subsubsection{Structural characterization of $B a(I I) F e(I I I)$ layered double hydroxide}

${ }^{57} \mathrm{Fe}$ Mössbauer spectra recorded for $\mathrm{Ba}(\mathrm{II})_{3} \mathrm{Fe}(\mathrm{III})-\mathrm{LDH}-10$ and $\mathrm{Ba}(\mathrm{II})_{3} \mathrm{Fe}(\mathrm{III})-$ LDH-20 were practically identical consisting of a singlet at IS $=0.40 \mathrm{~mm} / \mathrm{s}$ (Figs. 18), i.e., the local environments of Fe(III) were identical in the two samples. Thus, the suggestion [99-101] that $\mathrm{Ba}_{3}\left[\mathrm{Fe}(\mathrm{OH})_{6}\right]_{2}$ was formed at $\mathrm{c}_{\mathrm{NaOH}} \sim 10 \mathrm{M}$, while $\mathrm{Ba}_{2}\left[\mathrm{Fe}(\mathrm{OH})_{7}\right] \cdot 1 / 2 \mathrm{H}_{2} \mathrm{O}$ at $\mathrm{c}_{\mathrm{NaOH}} \sim 20 \mathrm{M}$ appears to be unlikely.

Very similar singlet has been found recently for $\mathrm{Na}_{3}\left[\mathrm{Fe}(\mathrm{OH})_{6}\right] \cdot x \mathrm{NaOH}$ [118], in which, as it was deduced from their XAFS spectra, the Fe(III) central atoms are in a highly symmetrical octahedral coordination environment (i.e., in $\left[\mathrm{Fe}(\mathrm{OH})_{6}\right]^{3-}$ ). Thus, it is very probable that the $\mathrm{Fe}(\mathrm{III})$ ions are also in octahedral environment in our $\mathrm{Ba}(\mathrm{II})_{3} \mathrm{Fe}(\mathrm{III})$ LDH-10 and $\mathrm{Ba}(\mathrm{II})_{3} \mathrm{Fe}(\mathrm{III})-\mathrm{LDH}-20$ samples, which is typical to the trivalent cations in LDHs [2]. 


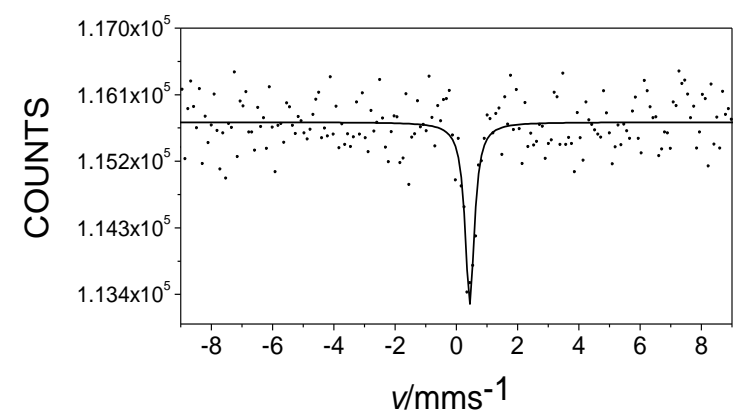

(a)

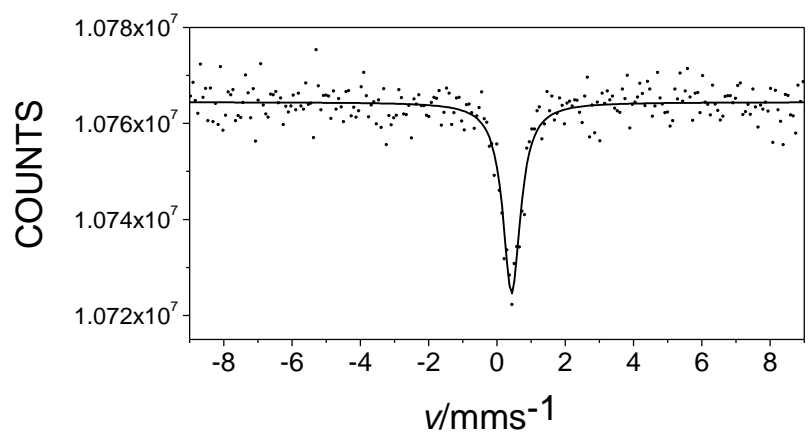

(b)

Fig. $18{ }^{57} \mathrm{Fe}$ Mössbauer spectra of $\mathrm{Ba}(\mathrm{II})_{3} \mathrm{Fe}(\mathrm{III})-\mathrm{LDH}$ obtained from solutions with (a) 10 $\mathrm{M}$ and (b) $20 \mathrm{M} \mathrm{NaOH}$ concentrations recorded at $78 \mathrm{~K}$.

The characteristic octahedral structure around the Fe(III) ion can be demonstrated by XAS measurements, too. Moreover, the method is able to provide quantitative information on the atomic environment of $\mathrm{Fe}(\mathrm{III})$, as far as bond lengths in the first, the second and the third coordination environments of the ion are concerned. Since this is not the method one uses on an every-day basis (except one is working at a synchrotron facility), the major characteristics of the method is shown shortly.

The absorption of the X-ray photon is based on the photo effect, i.e., the absorbed photon pushes out an electron from the inner shell of the bombarded atom or ion. The absorption coefficient decreases with the increase in energy, until it reaches the bonding energy of an inner electron. Then, a sharp peak appears in the spectrum. The corresponding energy is the so-called threshold energy. Beyond this energy a fine structure in the spectrum is seen up to even $10000 \mathrm{eV}$. The various regions of the $\mathrm{X}$-ray absorption provide different information (Fig. 19). 


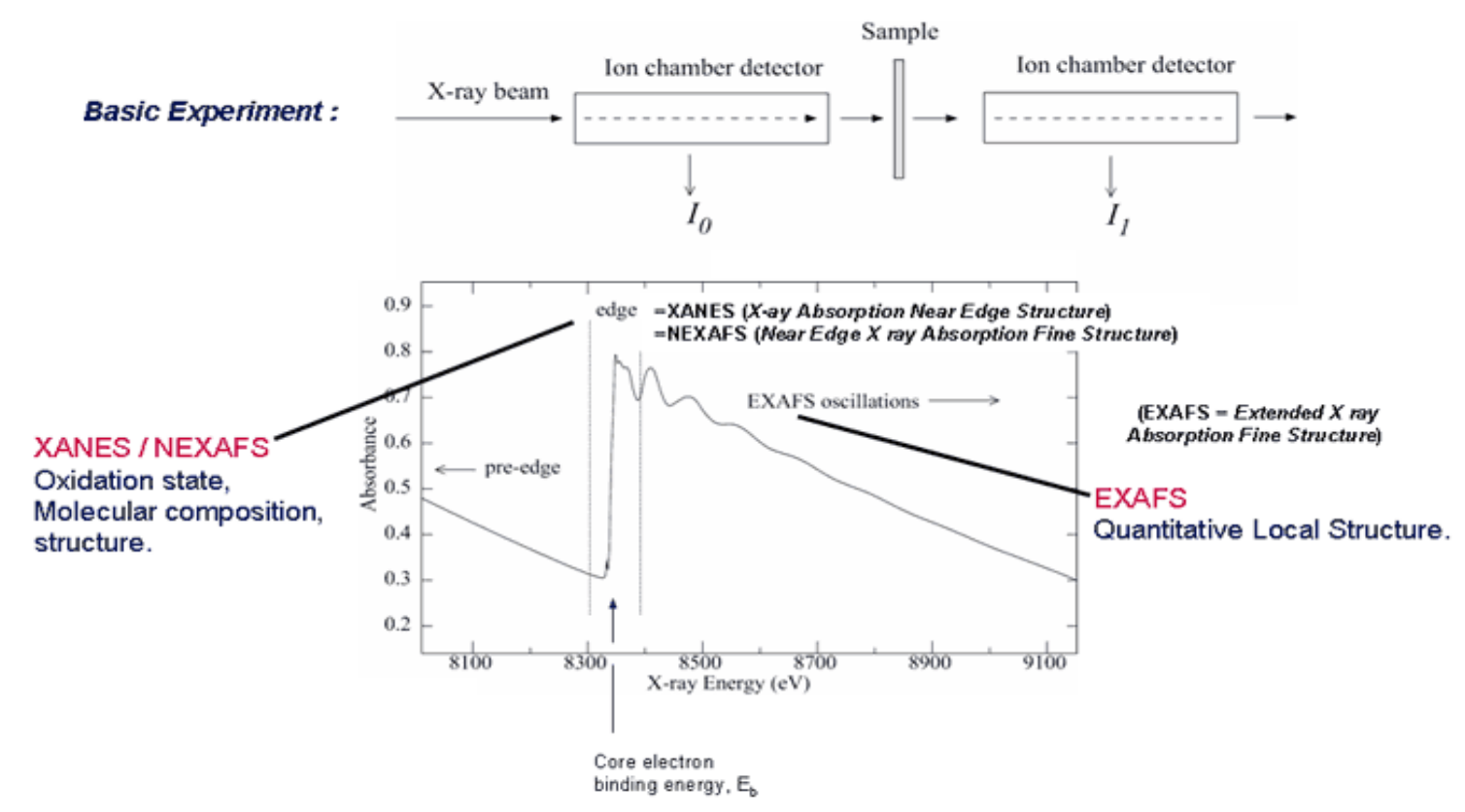

Fig. 19 The various regions of the X-ray absorption spectrum (XANES - X-ray absorption near-edge structure, EXAFS - Extended X-ray absorption fine structure).

The part of the spectrum before the absorption edge is the pre-edge region. Information on the bonding character, the oxidation state and the coordination geometry of the element studied can be extracted from it. Then, the absorption edge and its immediate surrounding follow - this is the XANES (X-ray Absorption Near-Edge Structure) region. This area also gives information on the oxidation state of the atom or ion and is influenced by the chemical properties of the ligands around the absorber. The last part is the EXAFS (Extended X-ray Absorption Fine Structure) region, from where structural parameters like coordination number, bond lengths, etc. can be extracted.

The EXAFS is always seen beyond the absorption edge, if the atom or ion absorbing the X-ray photon is surrounded by other atoms or ions, either solid or liquid state or molecular gases are considered. However, there is no EXAFS in noble gases or atomic vapors.

The fine structure after the absorption edge is due to the wave nature of the photoelectrons. On absorption of an X-ray photon, a photoelectron is expelled from an inner shell with a certain amount of kinetic energy being the difference between the energy of the X-ray photon $(\mathrm{E})$ and the bonding energy of the electron $\left(\mathrm{E}_{0}\right)$. These photoelectrons may be represented as spherical waves with a wavelength $(\lambda)$ : 


$$
\lambda=\frac{2 \pi}{k}
$$

where $k$ is the wave vector of the photoelectron:

$$
k=\sqrt{\frac{2 m\left(E-E_{o}\right)}{\hbar^{2}}}
$$

This electron wave is scattered on the neighboring atoms and ions, while new waves are starting from each scatterer. These waves interfere with the original wave (Fig. 20).

Fig. 20 Visualizing the original (red) and scattered spherical waves (blue); yellow is the incident X-ray photon.

The interference of the original and the scattered waves influences the probability of the photo effect. On increasing the energy of the photoelectrons, the wave vector of the photoelectron also changes, therefore both positive and negative interferences may appear. Normalizing the oscillatory part of the absorption coefficient with the atomic absorption, one arrives at the definition of EXAFS:

$$
\chi=\frac{\left(\mu-\mu_{o}\right)}{\mu_{o}}
$$

where $\mu_{o}$ is the atomic absorption. If only single scattering occurring on the atoms and/or ions immediately next to the absorber is taken into account, the EXAFS may be described with the sum of sinus waves as follows:

$$
\chi(k)=\sum_{i} A_{i}(k) \sin \left(2 k R_{i}+\delta_{i}\right)
$$

and

$$
A_{i}(k)=\frac{S_{o}^{2} e^{-\frac{2 R_{i}}{\lambda}}}{k R_{i}^{2}} \cdot N_{i} F_{i}(k) \cdot e^{-2 \sigma_{i}^{2} k^{2}}
$$


where

$i$ the $i^{\text {th }}$ of the member of the data

$A_{i}$ the amplitude factor

$R_{i}$ the distance between the absorber and the scatterers

$\delta_{i}$ the specific phase shift of the atom

$S_{o}{ }^{2}$ the reduction coefficient of the amplitude, which takes into account the effects of all the electrons excited at the same time

$N_{i}$ the number of scatterers in the $\mathrm{i}^{\text {th }}$ coordination shell

$F_{i}(k)$ the amplitude of the atoms of $\mathrm{i}^{\text {th }}$ coordination shell

$\sigma_{i}$ the Debye-Waller factor describing the temperature dependence of $\mathrm{R}_{\mathrm{i}}$ and the material disorder.

The EXAFS part of the spectrum reveals important structural information about the surrounding of the absorbing atom/ion. After Fourier transformation, the contributions of the coordination spheres are revealed. The peaks of the thus obtained pseudo-radial distribution function appear at $R_{i}$ distances providing with direct structural information. The distances become accessible after fitting a model function to the spectrum depicted either in the "k field" or in the Fourier-transformed "R field". The distances between the atoms (ions) can be determined accurately (less than $1 \%$ error), while the values of the coordination number and the Debye-Waller factor carry approximately $10 \%$ uncertainty. These pieces of information may be obtained for crystalline as well as amorphous and liquid materials or molecular gases, too.

In the XANES region, the electron transfers occur to unoccupied bonding orbitals in most cases, and with much less probability to the continuum. Changes in this region may serve a fingerprint for the materials. This region is the most sensitive to the changes in the geometry around the absorber atom or ion, i.e., very significant spectral changes may be observed. They are mainly due to the scattering of photoelectrons with low kinetic energies. Contrary to the EXAFS region, here, multiple scatterings have major role. Although in XANES the atoms/ions in the first coordination sphere predominate (Fig. 21), other strongly bound scatterers have important effects as well. 


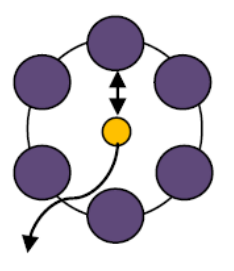

EXAFS

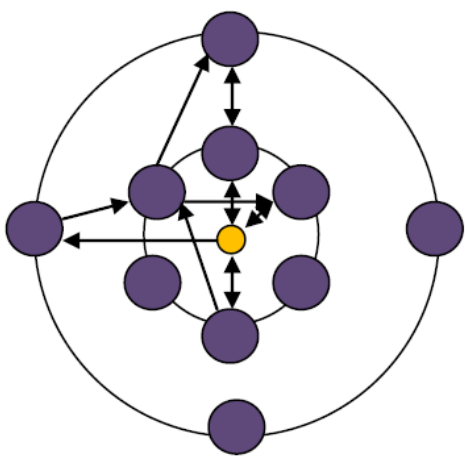

XANES

Fig. 21 Single and multiple scattering processes in the EXAFS and the XANES regions.

The other very important piece of information is the accurate position of the absorption edge corresponding to the oxidation state of the absorber atom or ion. In higher oxidation states the attraction between the nucleus and the electrons increases shifting the absorption edge towards higher energies. The shift is getting more and more appreciable with increase in atomic number and can reach values $6-8 \mathrm{eV}$ per oxidation number.

In the pre-edge regions one can obtain information of the geometry of the absorber. Tetrahedral geometry is indicated by the appearance of a peak, while the lack of it indicates close to perfect octahedral arrangement. Its gradual disappearance indicates distortion of the close to perfect tetrahedral or octahedral environment.

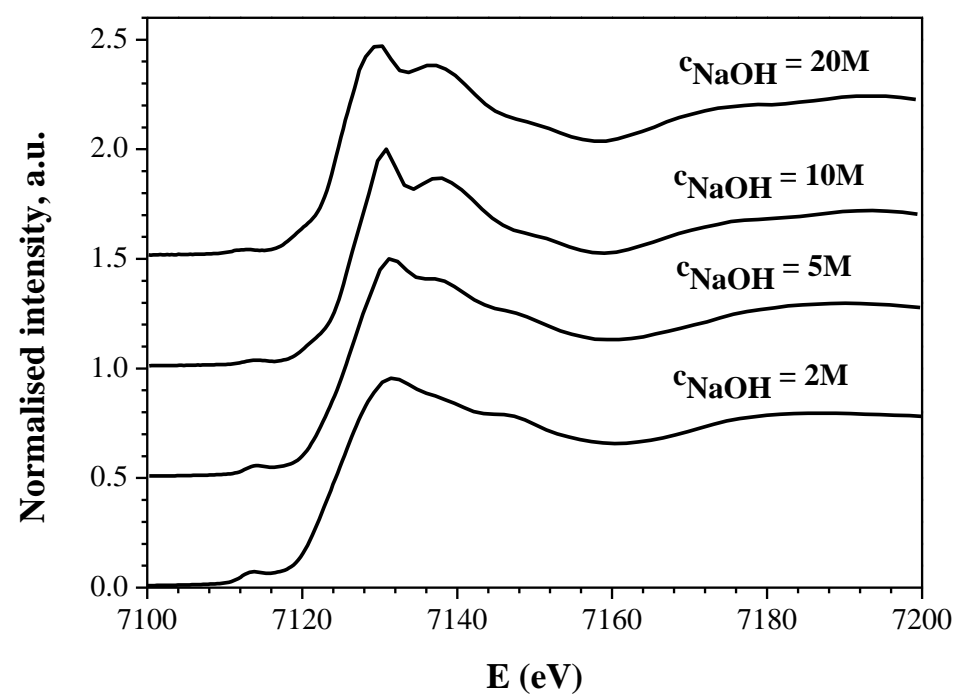

Fig. 22 Fe-K-edge X-ray absorption spectra of the solid substances obtained from solutions with varying concentrations of $\mathrm{NaOH}$. 
First, let us concentrate on the pre-edge regions of the observed X-ray absorption spectra of the solid materials obtained, when the concentration of the $\mathrm{NaOH}$ solutions, used for precipitation, was systematically changed (Fig. 22).

On the basis of the X-ray diffractograms we have already learnt that there was no LDH formation when the $\mathrm{NaOH}$ concentration was $2 \mathrm{M}$ or $5 \mathrm{M}$, however, when it was 10 M or $20 \mathrm{M}$, LDHs did form. These pieces of information completely coincide with the observation that the pre-edge peaks at $\sim 7115 \mathrm{eV}$ appeared for the materials precipitated at the two lower $\mathrm{NaOH}$ concentrations indicating distorted octahedral environment around the Fe(III) ion. The disappearance of the small maximum in the pre-edge region gives clear evidence of the close to perfect octahedral environment of the $\mathrm{Fe}$ (III) [118] at the two highest $\mathrm{NaOH}$ concentrations. This is another indication that LDH formation only occurred when $10 \mathrm{M}$ or $20 \mathrm{M} \mathrm{NaOH}$ was used for precipitation. Fig. 22 clearly shows that the spectra of BaFe-LDH-10 and BaFe-LDH-20 are very similar, thus the overall structure of the two LDHs were identical revealing that the local structure for the Fe(III) ions were also the same.

A comparison of the pseudo-radial distribution functions leads to the same conclusions (Fig. 23).

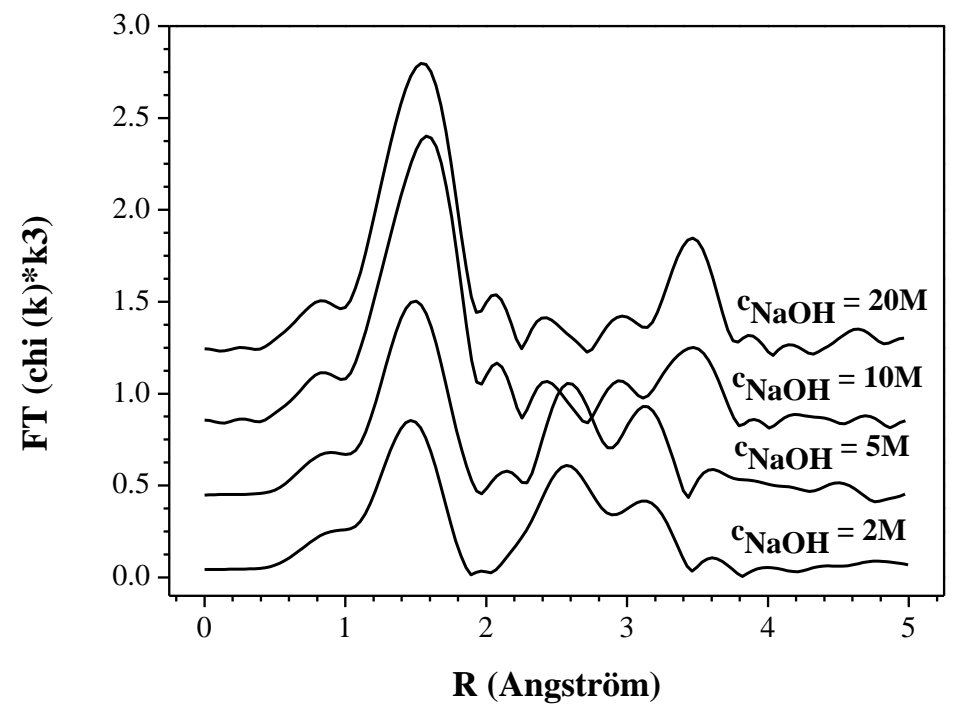

Fig. 23 The calculated pseudo-radial distribution functions of the $\mathrm{Ba}_{3} \mathrm{Fe}-\mathrm{LDH}$ precipitated with $2 \mathrm{M}, 5 \mathrm{M}, 10 \mathrm{M}$ or $20 \mathrm{M} \mathrm{NaOH}$ solution.

In the previous section we have shown that the layered structure collapsed around $520 \mathrm{~K}$. This experimental finding should be reflected in the XAS spectra registered on samples heat-treated at various temperatures before the measurements. The observed as 
well as the corresponding pseudo-radial distribution functions on the heat-treated samples (1-h treatment at the specified temperature) are displayed in Figs. 24 and 25.

It is seen especially in the pseudo-radial distribution functions that the layered structure is not harmed by the heat treatment either at $100{ }^{\circ} \mathrm{C}$ or $130{ }^{\circ} \mathrm{C}$. However, it starts to deteriorate on heat treatment at $180{ }^{\circ} \mathrm{C}$. The pre-edge peak at $7115 \mathrm{eV}$ appears on the observed spectrum and the pseudo-radial distribution function also starts to differ. On heat treatment at $250{ }^{\circ} \mathrm{C}$ the observed spectrum changes significantly: the pre-edge peak becomes more intense, by now the environment of the Fe(III) ion is tetrahedral rather than octahedral, and the XANES part looks also very different from those measured after lower pretreatment temperatures. The effect of heat treatment at this temperature is seen even more clearly on the pseudo-radial distribution function.

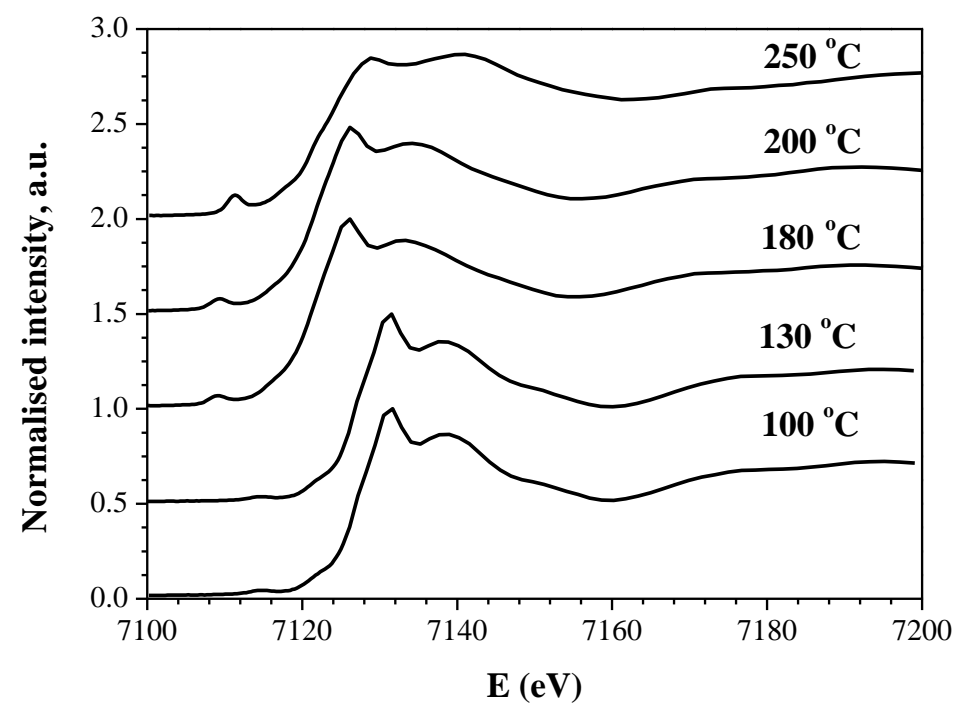

Fig. $24 \mathrm{XAS}$ spectra of the $\mathrm{Ba}(\mathrm{II})_{3} \mathrm{Fe}(\mathrm{III})-\mathrm{LDH}$ precipitated with $20 \mathrm{M} \mathrm{NaOH}$ solution after one-hour heat treatment at $100{ }^{\circ} \mathrm{C}(373 \mathrm{~K}), 130{ }^{\circ} \mathrm{C}(403 \mathrm{~K}), 180{ }^{\circ} \mathrm{C}(453 \mathrm{~K}), 200{ }^{\circ} \mathrm{C}$ $(473 \mathrm{~K})$ or $250{ }^{\circ} \mathrm{C}(523 \mathrm{~K})$. 


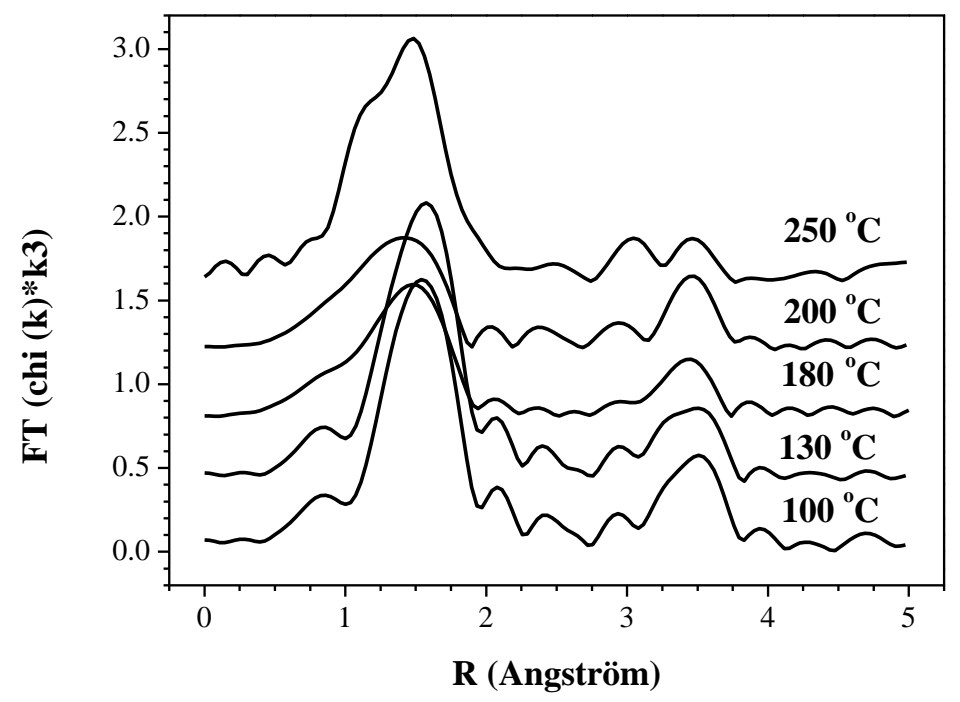

Fig. 25 The calculated pseudo-radial distribution functions of the $\mathrm{Ba}(\mathrm{III})_{3} \mathrm{Fe}(\mathrm{III})-\mathrm{LDH}$ precipitated with $20 \mathrm{M} \mathrm{NaOH}$ solution after one-hour heat treatment at $100{ }^{\circ} \mathrm{C}(373 \mathrm{~K})$, $130{ }^{\circ} \mathrm{C}(403 \mathrm{~K}), 180{ }^{\circ} \mathrm{C}(453 \mathrm{~K}), 200{ }^{\circ} \mathrm{C}(473 \mathrm{~K})$ or $250{ }^{\circ} \mathrm{C}(523 \mathrm{~K})$.

The EXAFS region indicates that above $130{ }^{\circ} \mathrm{C}$ the second and the third coordination spheres started to change. At $250{ }^{\circ} \mathrm{C}$ pre-treatment temperature even the first coordination sphere altered dramatically. These are unequivocal indications for the collapse of the layered structure. The quantitative analysis of the EXAFS spectrum of the $\mathrm{Ba}{ }_{3} \mathrm{Fe}-\mathrm{LDH}$ prepared by using the $20 \mathrm{M} \mathrm{NaOH}$ solution for precipitation was done with the EXAFSPAK package using the Marquardt algorithm. The model for calculating the theoretical scattering pathways was a structure in which iron was octahedrally surrounded by oxygen atoms, and the $\mathrm{Fe}-\mathrm{Fe}$ and $\mathrm{Fe}-\mathrm{Ba}$ pair-interactions were also taken into account. The most important structural parameters provided by this modeling are the average coordination number $\left(\mathrm{N}_{\mathrm{j}}\right)$, the bond distances $(\mathrm{R})$ and the Debye-Waller factor $\left(\sigma^{2}\right)$ characterizing the thermal fluctuation of the bond distances. The resolution of the bond distances in the "k region" (2.5-14 keV) was $14 \mathrm{pm}$.

Table 2 Structural parameters obtained by the quantitative treatment of the XAS spectrum of $\mathrm{Ba}(\mathrm{II})_{3} \mathrm{Fe}(\mathrm{III})-\mathrm{LDH}$.

\begin{tabular}{|c|c|c|c|}
\hline & \multicolumn{3}{|c|}{ Structural parameters } \\
\hline & $\mathrm{N}$ & $\mathrm{R}(\mathrm{pm})$ & $\sigma^{2}$ \\
\hline $\mathrm{Fe}-\mathrm{O}^{\mathrm{a}}$ & 6.12 & 201 & 0.0066 \\
\hline $\mathrm{Fe}-\mathrm{Fe}^{\mathrm{b}}$ & 2.79 & 295 & 0.02953 \\
\hline $\mathrm{Fe}-\mathrm{Ba}^{\mathrm{b}}$ & 5.67 & 372 & 0.01262 \\
\hline $\mathrm{Fe}-\mathrm{O}^{\mathrm{c}}$ & 9.57 & 398 & 0.00455 \\
\hline
\end{tabular}

$\mathrm{a}, \mathrm{b}$ and $\mathrm{c}$ are the first, second and third coordination spheres, respectively. 
Structural parameters reveal that the geometry around the Fe(III) ion is a slightly distorted octahedron. In the second coordination sphere the Ba:Fe ratio is close to 3, i.e., there are approximately three times as many $\mathrm{Ba}-\mathrm{Fe}$ pair interactions than $\mathrm{Fe}-\mathrm{Fe}$ ones at ca. 293-295 pm. This again shows that the metal ions forming these compounds are not segregated just as it is expected in double hydroxides.

On the basis of the above parameters an approximate arrangement for a layer is given in Fig. 26. Let me note, however, that this not a calculated model, thus it should be used only for visualization. Accurate quantum mechanical calculating is currently beyond the capability of our computational resources even for one layer of the LDH.

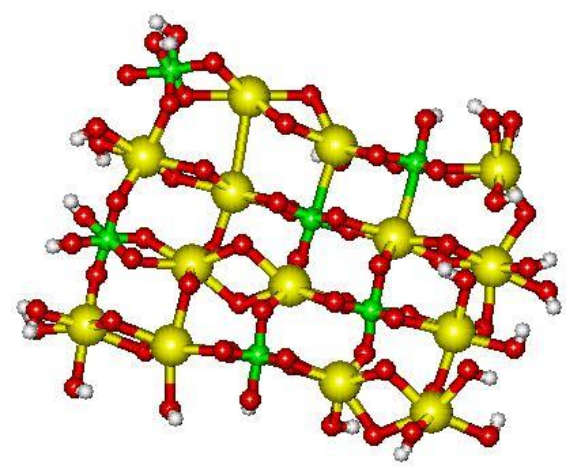

Fig. 26 A schematic drawing (only) to help the visualization of a layer segment. (Large balls represent the barium ions, the smaller ones indicate iron ions, while oxygen atom are in bridge positions; the segment is closed by hydrogen atom.)

To sum up, it was possible to obtain quantitative structural data about $\mathrm{Ba}(\mathrm{II})_{3} \mathrm{Fe}(\mathrm{III})$ $\mathrm{LDH}$, both as far as the coordination of the Fe(III) ion in the first coordination sphere and the $\mathrm{Fe}-\mathrm{O}(\mathrm{Ba}, \mathrm{Fe}, \mathrm{O})$ distances in the first to third coordination spheres are concerned, by the XAS method. The coordination environment of the Fe(III) was found to be octahedral in the $\mathrm{LDH}$, while from $453 \mathrm{~K}$ and above the $\mathrm{LDH}$ structure deteriorated and from now on the environment gradually turned tetrahedral. Changes are seen in the second and third coordination sphere first, then, at $523 \mathrm{~K}$ the first coordination sphere also altered significantly indicating the collapse of the layered structure. The $\mathrm{Fe}-\mathrm{O}$ distance in the $\mathrm{LDH}$ is $\sim 200 \mathrm{pm}$ and $\sim 400 \mathrm{pm}$ in the first and third coordination spheres, respectively. In the second coordination sphere $\mathrm{Fe}(\mathrm{III})$ and $\mathrm{Ba}(\mathrm{II})$ ions are found at $\sim 300 \mathrm{pm}$. 
5.1.3. Syntheses and characterization of $M g(I I) F e(I I I)$ and $C a(I I) F e(I I I)$ layered double hydroxides

$\mathrm{Mg}(\mathrm{II}) \mathrm{Fe}(\mathrm{III})-$ and $\mathrm{Ca}(\mathrm{II}) \mathrm{Fe}(\mathrm{III})-\mathrm{LDH}$ are already known from the literature (for the relevant XRD data, see $[87,97,98])$.

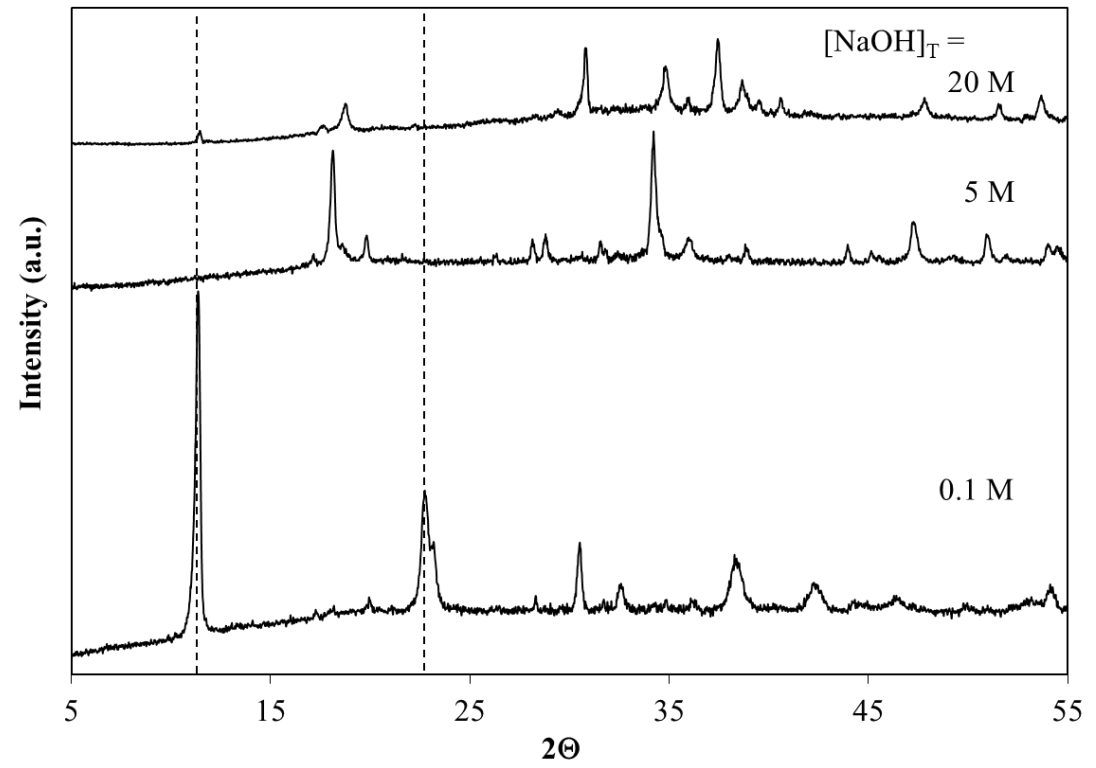

Fig. $27 \mathrm{XRD}$ patterns of the freshly prepared and air-dried $\mathrm{Ca}(\mathrm{II})_{3} \mathrm{Fe}(\mathrm{III})-\mathrm{LDH}$ with varying $[\mathrm{NaOH}]_{\mathrm{T}}$.

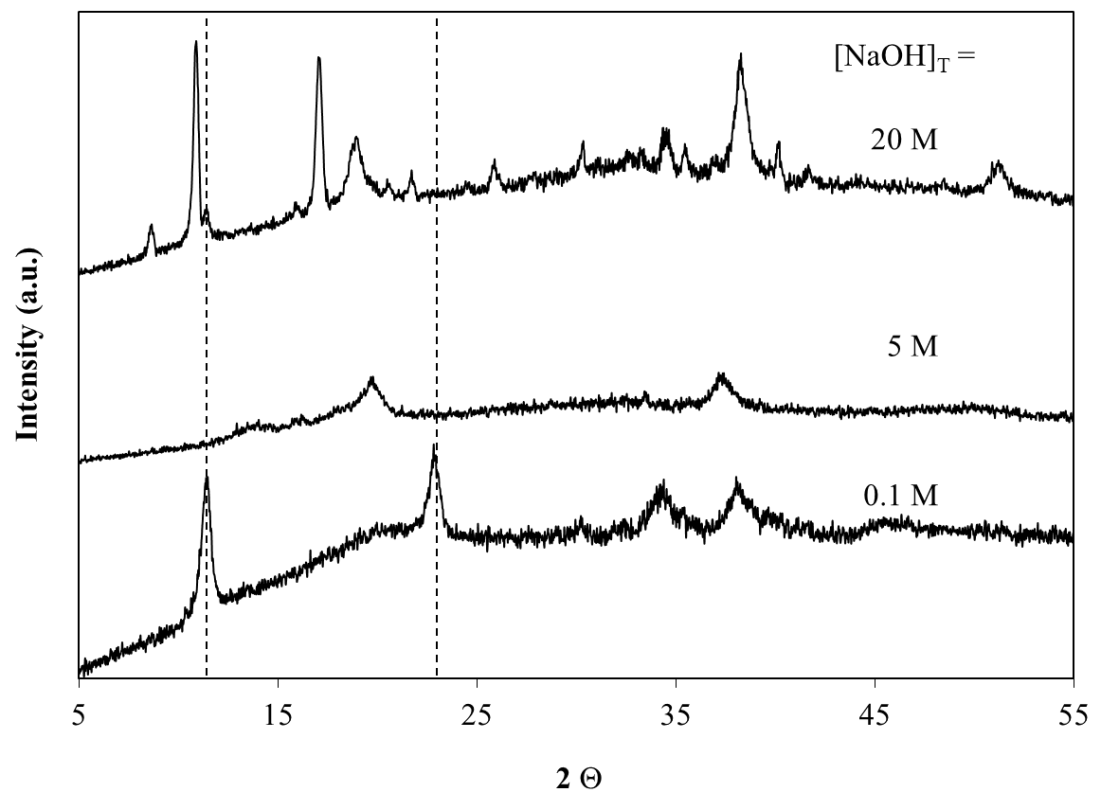

Fig. $28 \mathrm{XRD}$ patterns of the freshly prepared and air-dried $\mathrm{Mg}(\mathrm{II})_{3} \mathrm{Fe}(\mathrm{III})-\mathrm{LDH}$ with varying $[\mathrm{NaOH}]_{\mathrm{T}}$. 
Nevertheless, Figs. 27 and 28 attest that the syntheses did not work under highly (5 $\mathrm{M} \mathrm{NaOH})$ or hyperalkaline $(20 \mathrm{M} \mathrm{NaOH})$ conditions either because layered double hydroxide were not formed (Figs. 27 and 28 at $5 \mathrm{M} \mathrm{NaOH}$ ) or because the ratio of secondary products (Fig. 28 at $20 \mathrm{M} \mathrm{NaOH}$ ) was too high. However, when the final $\mathrm{NaOH}$ concentration was set to $0.1 \mathrm{M}$, the major or the exclusive products were layered double hydroxides.

The preparation protocols of both LDH types were optimized through varying the $\mathrm{NaOH}$ concentrations (not exceeding $5 \mathrm{M} \mathrm{NaOH}$, however), the ratio of the di- and trivalent ions and excluding the $\mathrm{CO}_{2}$ of air by blanketing the reaction mixture with $\mathrm{N}_{2}$ or not. In methods $A$ and $B$ the final $\mathrm{NaOH}$ concentrations were set to $0.1 \mathrm{M}$, in methods $C$, and $D$ they were $1.875 \mathrm{M}$ and $2.55 \mathrm{M}$, respectively. In method $B \mathrm{~N}_{2}$-blanketing was applied.

Nearly each combination resulted in LDH formation except for $\mathrm{Mg}(\mathrm{II}) \mathrm{Fe}$ (III)-LDH for method $D$, at $\operatorname{Mg}(\mathrm{II}): \mathrm{Fe}(\mathrm{III})$ ratio higher than $2: 1$. The interlayer spacing values calculated from the first (the 003) reflections are given in Tables 3 and 4. However, secondary products (it was $\mathrm{M}(\mathrm{OH})_{2}$ of high $\mathrm{M}(\mathrm{II}) / \mathrm{Fe}(\mathrm{III})$ ratio) were also formed during precipitation (Figs. 29 and $\mathbf{3 0}$ - reflections belonging to side products are marked with asterisks). However, they often could be removed via washing with distilled water.

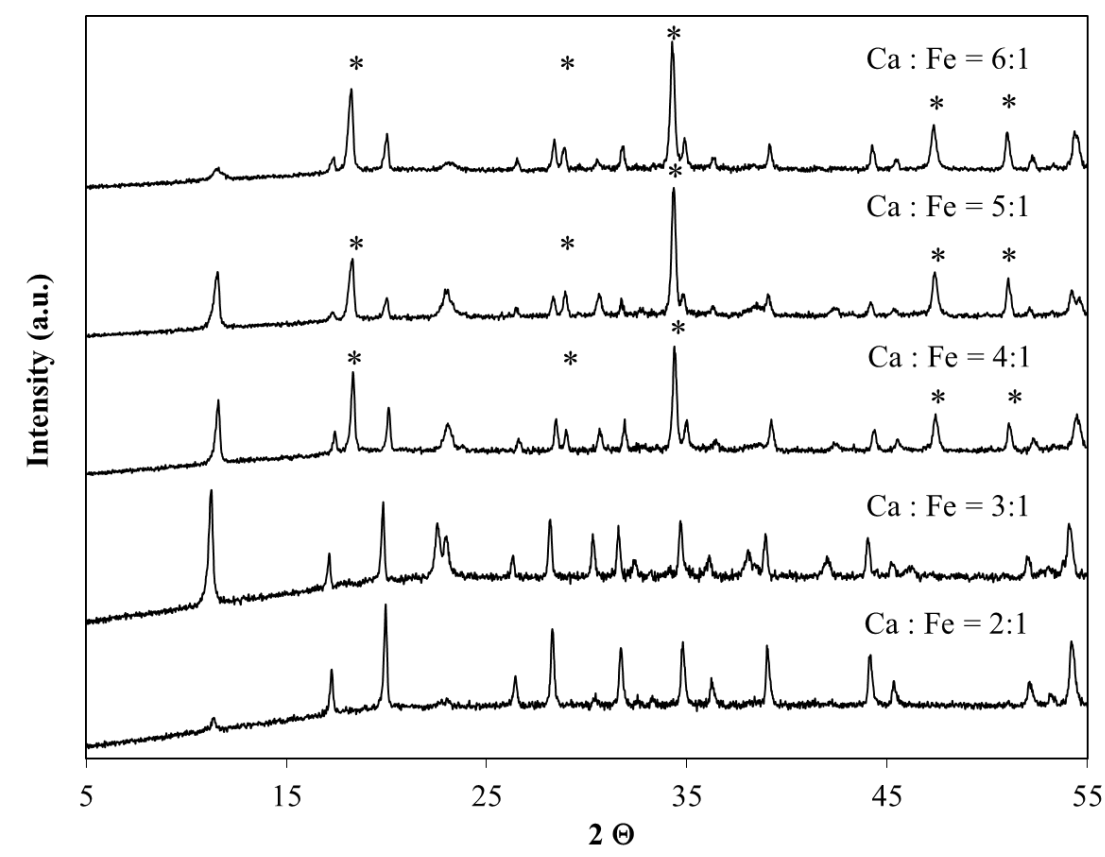

Fig. $29 \mathrm{XRD}$ patterns of the freshly prepared and air-dried CaFe-LDH. The final $[\mathrm{NaOH}]_{\mathrm{T}}$ was $1.875 \mathrm{M}$ in the synthesis solution. Reflections associated with $\mathrm{Ca}(\mathrm{OH})_{2}$ side product are indicated with *. 


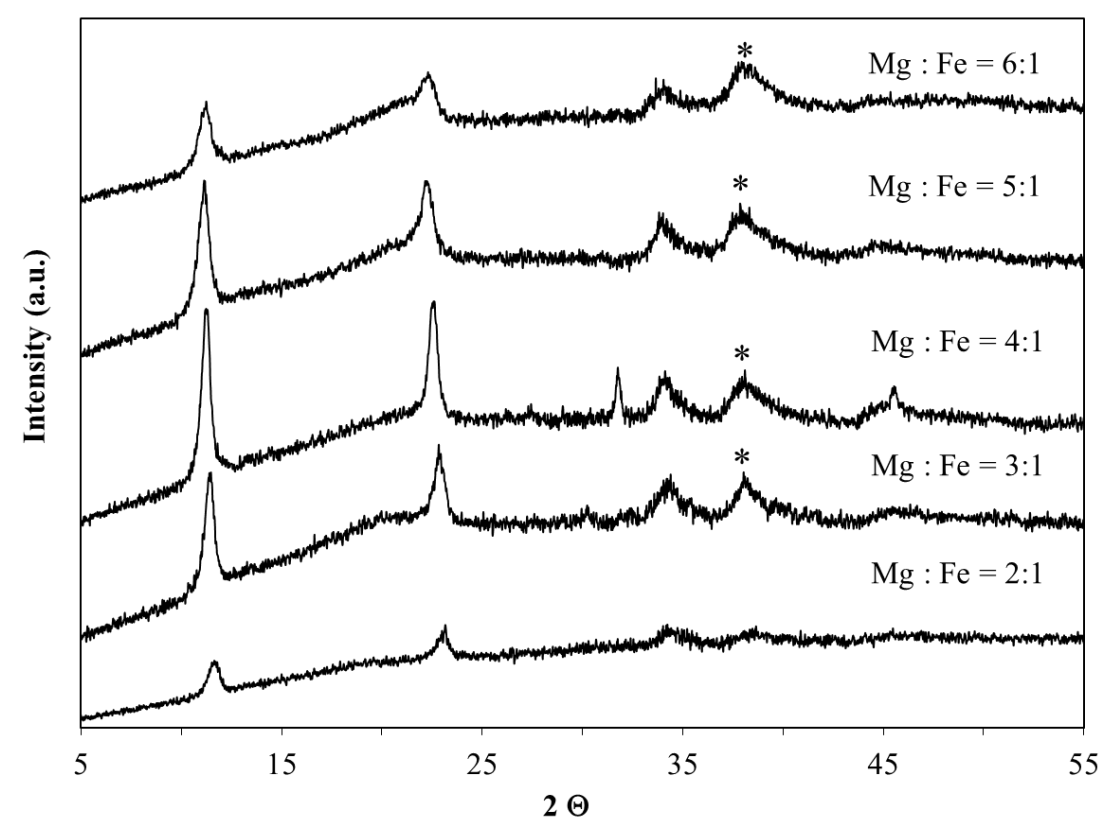

Fig. 30 XRD patterns of the freshly prepared and air-dried CaFe-LDH. The final $[\mathrm{NaOH}]_{\mathrm{T}}$ was $1.875 \mathrm{M}$ in the synthesis solution. Reflections associated with $\mathrm{Mg}(\mathrm{OH})_{2}$ side product are indicated with *.

Table 3 Interlayer distance $(\mathrm{d} / \AA \AA)$ (calculated from the position of the first reflection) for $\mathrm{Mg}(\mathrm{II}) \mathrm{Fe}(\mathrm{III})-\mathrm{LDHs}$ having various di- to trivalent metal ratios prepared according to different synthesis protocols.

\begin{tabular}{cccccc}
\hline & \multicolumn{5}{c}{$M g(\mathrm{II}): \mathrm{Fe}(\mathrm{III})$ molar ratio } \\
\cline { 2 - 6 } Method $^{\text {a }}$ & $2: 1$ & $3: 1$ & $4: 1$ & $5: 1$ & $6: 1$ \\
\cline { 2 - 6 } & 7.96 & 7.98 & 8.09 & 8.06 & 8.12 \\
\hline A & 7.98 & 8.01 & 7.99 & 8.23 & 8.06 \\
B & 7.58 & 7.71 & 7.85 & 7.93 & 7.88 \\
C & 7.93 & 4.78 & 7.75 & 4.41 & 4.69 \\
D & & & & \\
\hline
\end{tabular}

a) Methods $A$ and $B$ : the final $\mathrm{NaOH}$ concentrations were set to $0.1 \mathrm{M}$; in method $B, \mathrm{CO}_{2}$ in the air surrounding the reaction mixture was expelled by $\mathrm{N}_{2}$. Methods $C$ and $D$ : the final concentration of the $\mathrm{NaOH}$ solution was $1.875 \mathrm{M}$ and $2.55 \mathrm{M}$, respectively. 
Table 4 Interlayer distance $(\mathrm{d} / \AA \AA)$ (calculated from the position of the first reflection) for $\mathrm{Ca}(\mathrm{II}) \mathrm{Fe}$ (III)-LDHs having various di- to trivalent metal ratios prepared according to different synthesis protocols.

\begin{tabular}{cccccc}
\hline & \multicolumn{5}{c}{$\mathrm{Ca}(\mathrm{II}): \mathrm{Fe}(\mathrm{III})$ mol ratio } \\
\cline { 2 - 6 } Method $^{\mathrm{a}}$ & $2: 1$ & $3: 1$ & $4: 1$ & $5: 1$ & $6: 1$ \\
\cline { 2 - 6 } & 7.89 & 7.78 & 7.63 & 7.59 & 7.69 \\
\hline A & 7.82 & 7.74 & 7.75 & 7.54 & 7.61 \\
B & 7.78 & 7.79 & 7.65 & 7.67 & 7.66 \\
C & 7.73 & 7.75 & 7.75 & 7.73 & 7.77 \\
D & & & & & \\
& & & & & \\
\hline
\end{tabular}

a) Methods $A$ and $B$ : the final $\mathrm{NaOH}$ concentrations were $0.1 \mathrm{M}$; in method $B, \mathrm{CO}_{2}$ in the air surrounding the reaction mixture was expelled by $\mathrm{N}_{2}$. Methods $C$ and $D$ : the final concentration of the $\mathrm{NaOH}$ solution was $1.875 \mathrm{M}$ and $2.55 \mathrm{M}$, respectively.

Data reveal that $0.1 \mathrm{M}$ concentration for the $\mathrm{NaOH}$ solution is adequate for the successful synthesis for both LDH types and using $\mathrm{N}_{2}$ blanket is advantageous if one does not want the strongly adhering $\mathrm{CO}_{3}{ }^{2-}$ ions to be present among the $\mathrm{LDH}$ layers.

For more detailed investigations, described in the followings, the $\mathrm{Mg}_{4} \mathrm{Fe}-\mathrm{LDH}$ and the $\mathrm{Ca}_{3} \mathrm{Fe}-\mathrm{LDH}$ samples were chosen, since they were completely (the $\mathrm{Ca}_{3} \mathrm{Fe}-\mathrm{LDH}$ ) or nearly completely $\left(\mathrm{Mg}_{4} \mathrm{Fe}-\mathrm{LDH}\right)$ phase pure.

SEM images also indicated the layered structure for both chosen samples (Fig. 31: $\mathrm{Ca}(\mathrm{II})_{3} \mathrm{Fe}(\mathrm{III})-\mathrm{LDH}$ and Fig. 32: $\left.\mathrm{Mg}(\mathrm{II})_{4} \mathrm{Fe}(\mathrm{III})-\mathrm{LDH}\right)$. This can be taken as good luck, since arrangement at the atomic level is not always reflected in the morphology of the materials. 

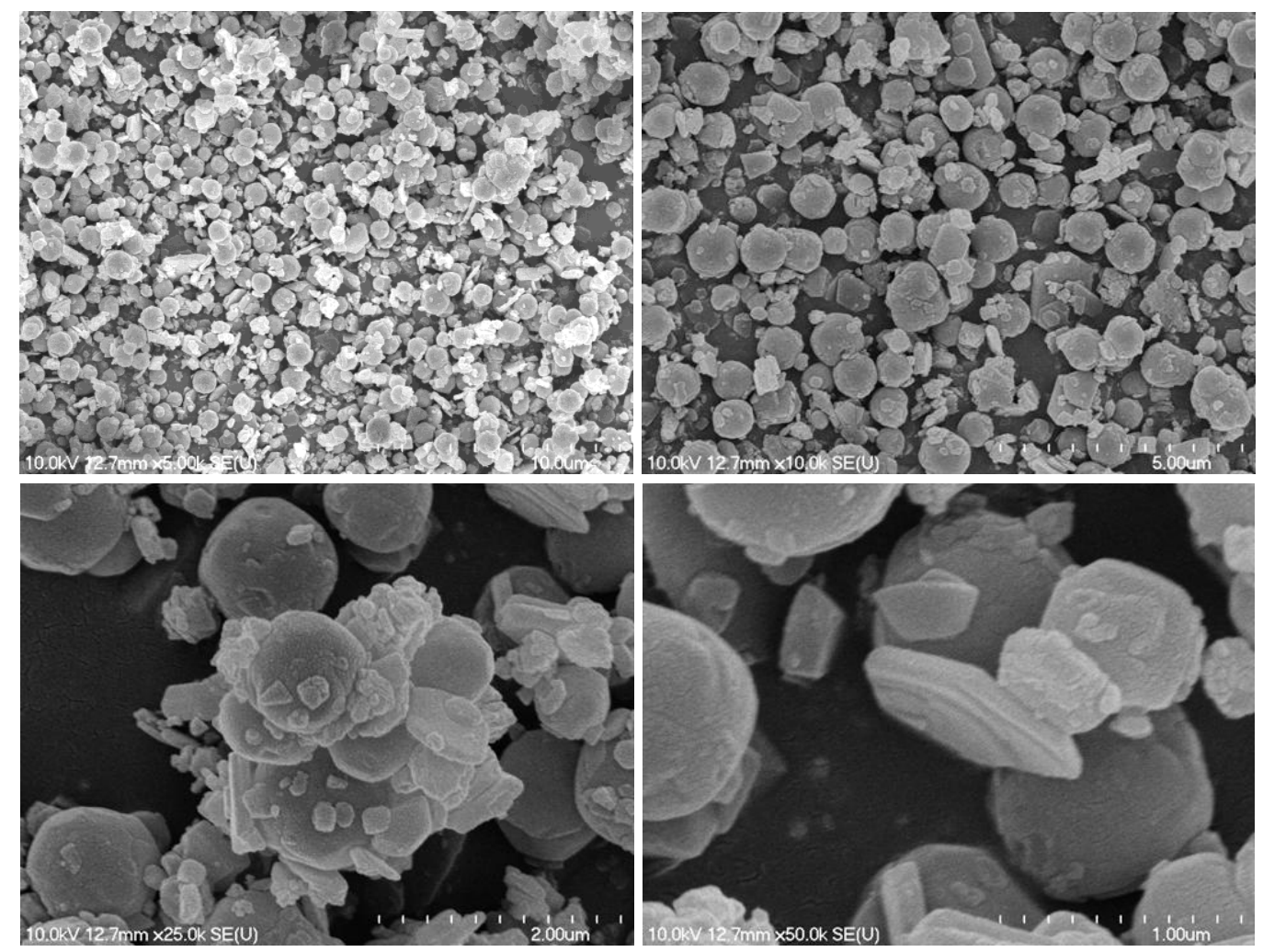

Fig. 31 SEM images of $\mathrm{Ca}(\mathrm{II})_{3} \mathrm{Fe}(\mathrm{III})-\mathrm{LDH}$ at magnifications of 5,000, 10,000, 25,000 and 50,000 .
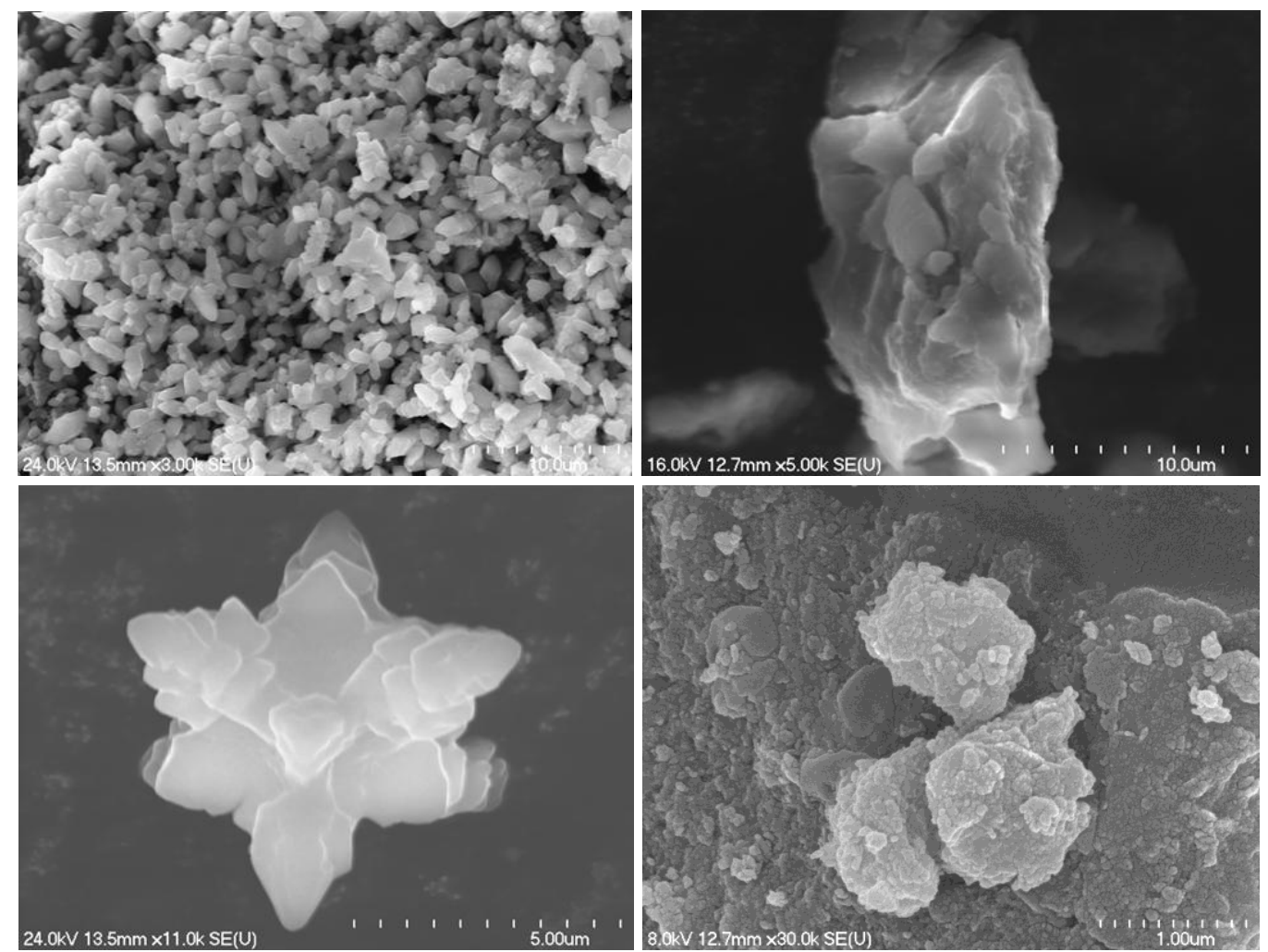

Fig. 32 SEM images of $\mathrm{Mg}(\mathrm{II})_{4} \mathrm{Fe}(\mathrm{III})-\mathrm{LDH}$ at magnifications of 3,000, 5,000, 11,000 and 30,000 . 
The di- and trivalent metal ions are largely evenly distributed as is seen in the SEM-EDX elemental maps (Figs. 33 and 34).

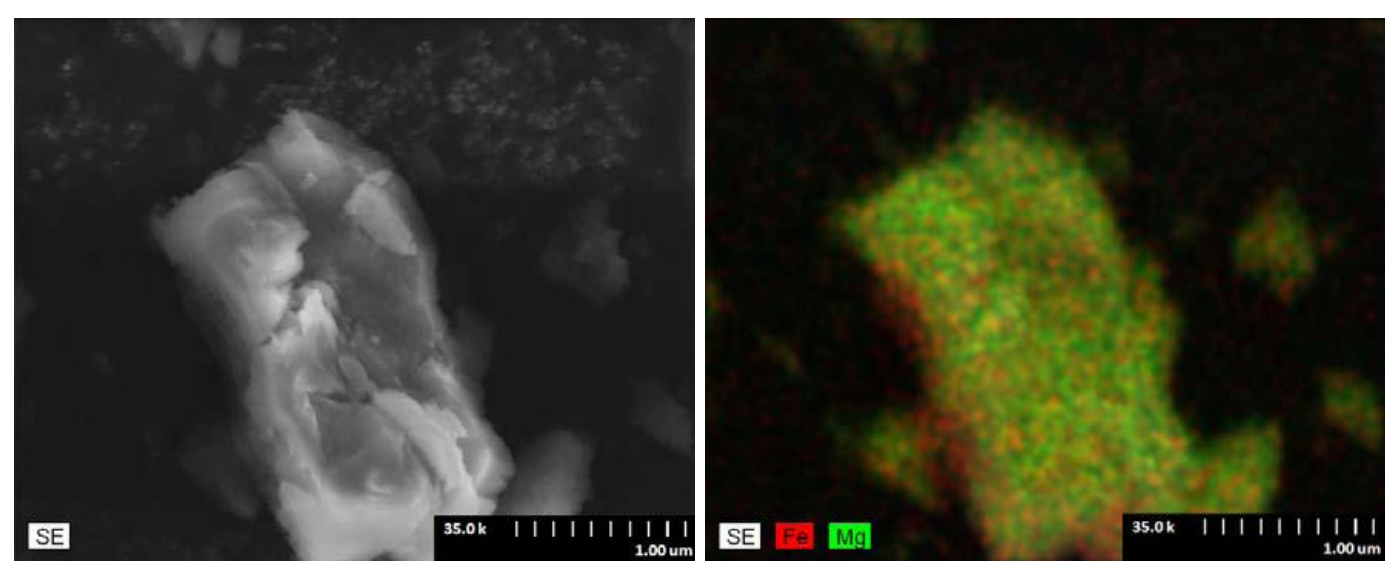

Fig. 33 Elemental map of $\mathrm{Mg}(\mathrm{II})_{4} \mathrm{Fe}(\mathrm{III})-\mathrm{LDH}$ precipitated with $\mathrm{NaOH}$ set to $0.1 \mathrm{M}$ on the sample with magnification of 35,000 .
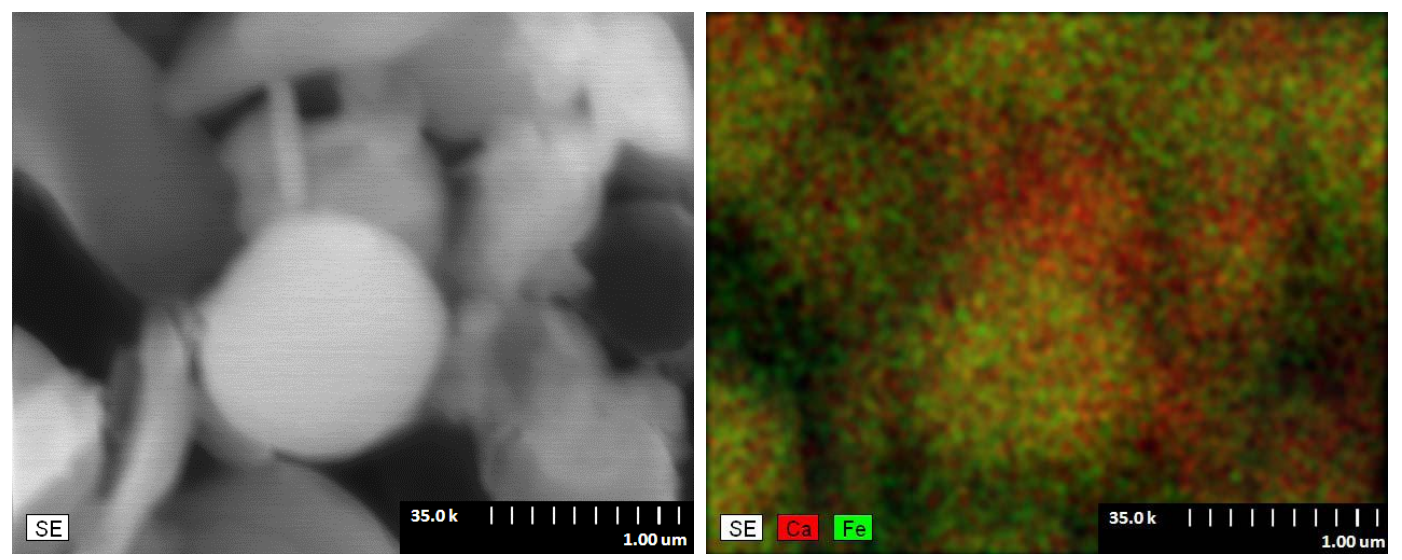

Fig. 34 Elemental map of $\mathrm{Ca}(\mathrm{II})_{3} \mathrm{Fe}(\mathrm{III})-\mathrm{LDH}$ precipitated with $\mathrm{NaOH}$ set to $0.1 \mathrm{M}$ on the sample with magnification of 35,000 .

The thermal behavior of these two LDHs was also typical of this family of materials [128] (Figs. 35 and 36). Until the collapse of the layered structure, water loss occurred in three major steps: first, desorption of physisorbed water, then removal of interlayer water and finally, the loss of structural water (it is in the form of structural $\mathrm{OH}$ groups) leading to the deterioration of the layered structure. The temperature ranges differed for the two compounds $\left(\mathrm{Mg}_{4} \mathrm{Fe}-\mathrm{LDH}: 80-100{ }^{\circ} \mathrm{C}, 110-200{ }^{\circ} \mathrm{C}, 250-410{ }^{\circ} \mathrm{C}\right.$; $\mathrm{Ca}_{3} \mathrm{Fe}-\mathrm{LDH}:{ }^{100}-150{ }^{\circ} \mathrm{C}, 175-350{ }^{\circ} \mathrm{C}, 400-475^{\circ} \mathrm{C}$ ) and the third step for the $\mathrm{Mg}_{4} \mathrm{Fe}-\mathrm{LDH}$ sample was split into two indicating two types of structural $\mathrm{OH}$ groups. 


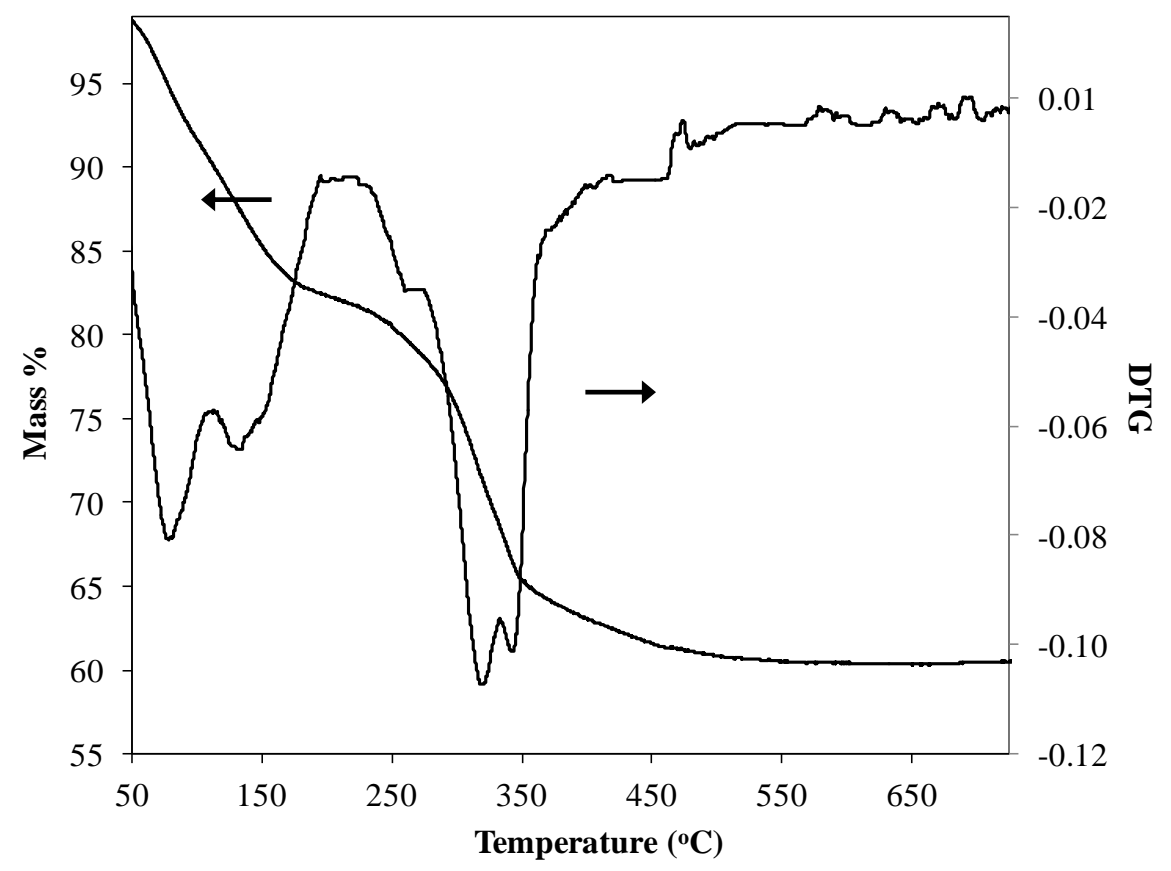

Fig. $35 \mathrm{TG}$ and DTG curves for $\mathrm{Mg}(\mathrm{II})_{3} \mathrm{Fe}(\mathrm{III})-\mathrm{LDH}$.

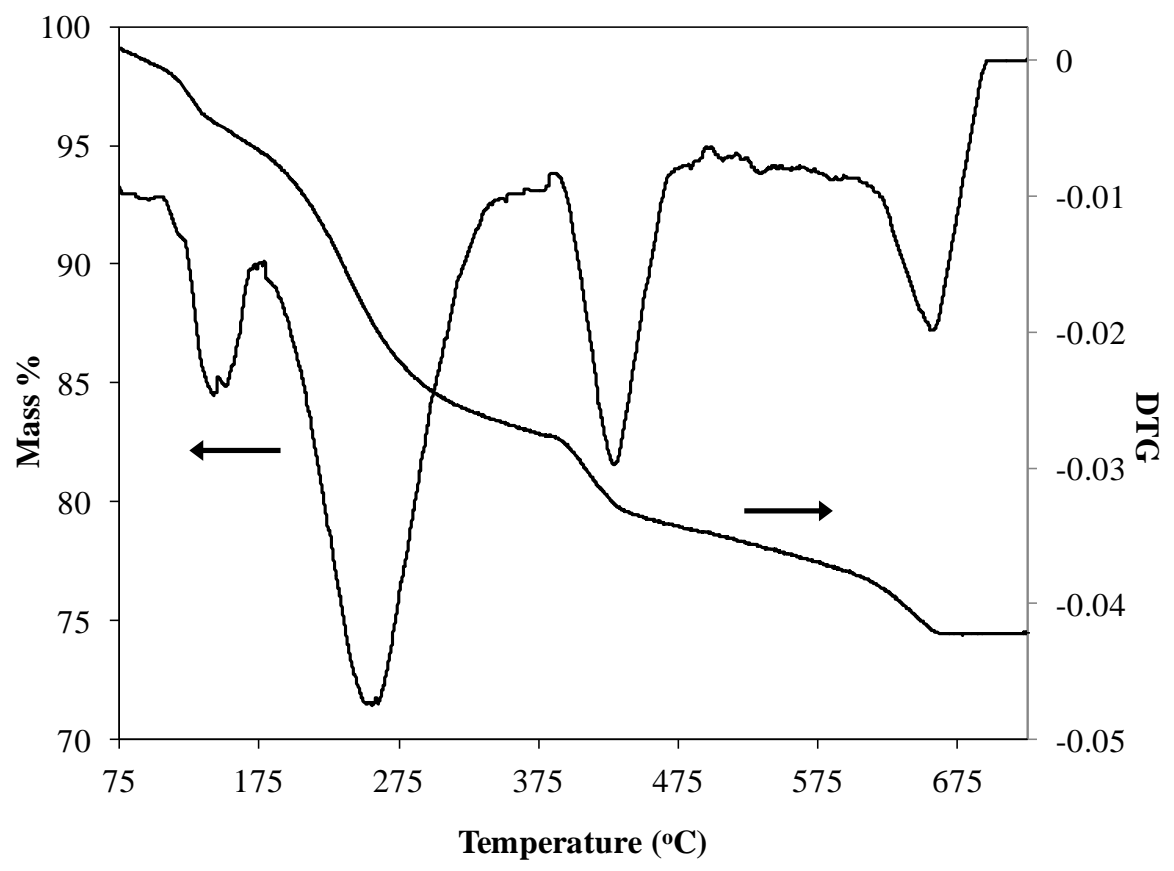

Fig. $36 \mathrm{TG}$ and DTG curves for $\mathrm{Ca}(\mathrm{II})_{3} \mathrm{Fe}(\mathrm{III})-\mathrm{LDH}$.

The FT-IR spectra (Fig. 37) indicate the presence of isolated (Ca(II) $)_{3} \mathrm{Fe}(\mathrm{III})-\mathrm{LDH}$ : $3640 \mathrm{~cm}^{-1}, \mathrm{Mg}(\mathrm{II})_{4} \mathrm{Fe}(\mathrm{III})-\mathrm{LDH}: 3731 \mathrm{~cm}^{-1}$ ) as well as hydrogen-bonded $\mathrm{OH}$ groups in both samples (the broad bands above $3000 \mathrm{~cm}^{-1}$ ). This hydrogen-bonded network is among $\mathrm{OH}$ groups and water molecules adsorbed on the outer surface as well as present in the 
interlayer spacing. This band is much broader for $\mathrm{Mg}(\mathrm{II})_{4} \mathrm{Fe}(\mathrm{III})-\mathrm{LDH}$ indicating more extended hydrogen-bonded network.

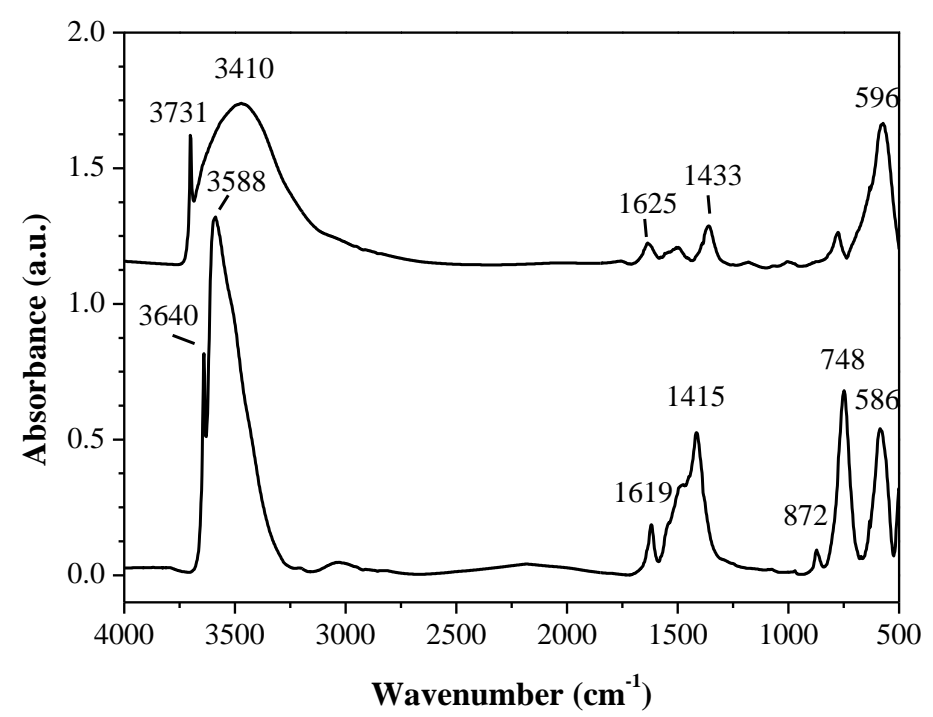

Fig. 37 FTIR spectra of the $\mathrm{Mg}(\mathrm{II})_{4} \mathrm{Fe}(\mathrm{III})-\mathrm{LDH}$ and $\mathrm{Ca}(\mathrm{II})_{3} \mathrm{Fe}(\mathrm{III})-\mathrm{LDH}$ samples.

Bands near $1620 \mathrm{~cm}^{-1}\left(\mathrm{Mg}_{4} \mathrm{Fe}-\mathrm{LDH}: 1625 \mathrm{~cm}^{-1}, \mathrm{Ca}_{3} \mathrm{Fe}-\mathrm{LDH}: 1619 \mathrm{~cm}^{-1}\right)$ are due to the deformation vibrations of the interlayer water molecules. Bands under $1000 \mathrm{~cm}^{-1}$ may be assigned to the $\mathrm{O}-$ metal ion-O units of the layers.

Since chloride salts and $\mathrm{NaOH}$ were used in the synthesis $\mathrm{Cl}^{-}$and $\mathrm{OH}^{-}$ions were the main interlayer anions. It should be noted that the band typical of the carbonate ion $\left(\sim 1360 \mathrm{~cm}^{-1}\right)$ is not seen in the spectra, therefore it is present in insignificant quantities among the layers.

\subsubsection{Syntheses and characterization of $\mathrm{Sr}(\mathrm{II}) \mathrm{Fe}(\mathrm{III})$ layered(?) double hydroxide}

After synthesizing $\mathrm{Mg}(\mathrm{II}) \mathrm{Fe}(\mathrm{III})$ - and $\mathrm{Ca}(\mathrm{II}) \mathrm{Fe}(\mathrm{III})-\mathrm{LDHs}$, and becoming more experienced in the preparation of $\mathrm{Ba}(\mathrm{II}) \mathrm{Fe}(\mathrm{III})-\mathrm{LDHs}$ under hyperalkaline conditions, it was expected that $\mathrm{Sr}(\mathrm{II}) \mathrm{Fe}(\mathrm{III})-\mathrm{LDHs}$ would also be successfully prepared either by the method in general use for $\mathrm{Mg}$ (II)Fe(III)- or $\mathrm{Ca}(\mathrm{II}) \mathrm{Fe}(\mathrm{III})$-LDHs (and many others) or under hyperalkaline conditions. 
The initial results were promising: white platelets [i.e., $\mathrm{Fe}(\mathrm{OH})_{3}$ was not precipitated] with peculiar morphology by SEM micrographs (Fig. 38) were obtained even with $2 \mathrm{M} \mathrm{NaOH}$.
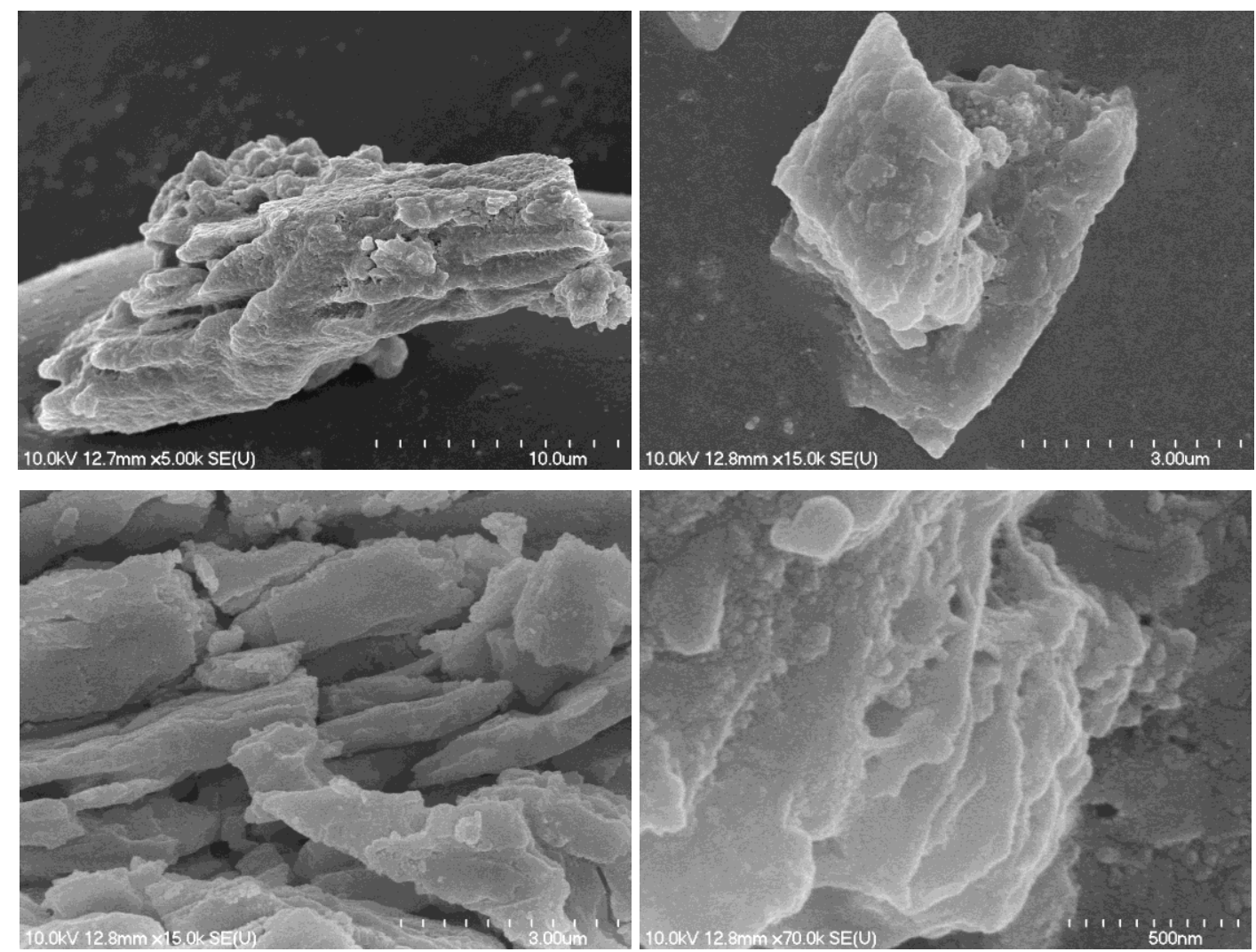

Fig. 38 SEM images of SrFe-precipitate at magnifications of 5,000, 15,000 and 70,000.
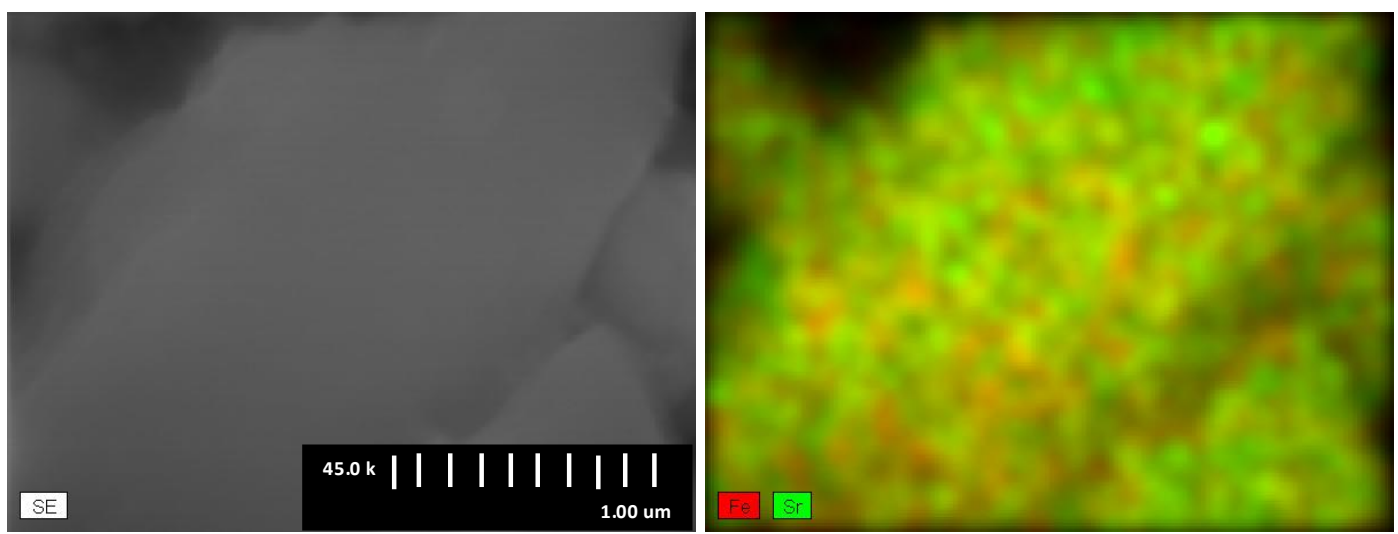

Fig. 39 Elemental distribution map of $\mathrm{Sr}_{3} \mathrm{Fe}$-precipitate at a magnification of 45,000 (2 M $\mathrm{NaOH}$ solution was used for co-precipitation). 
Moreover, through a largely even distribution of the di- and trivalent ions, the SEM-EDX elemental map indicated that double hydroxide was formed, indeed (Fig. 39).

The corresponding EDX spectrum is displayed in Fig. 40. These measurements were performed at six different locations of the same sample, and the average concentration of strontium and iron were 9.4 at $\%$ and 3.23 at $\%$, respectively. This corresponds to a $\mathrm{Sr}$ (II) to $\mathrm{Fe}$ (III) ratio of 2.91, close enough to the initial 3:1 molar ratio of the salts used during the synthesis. The intense aluminum and carbon signals are from the sample holder.

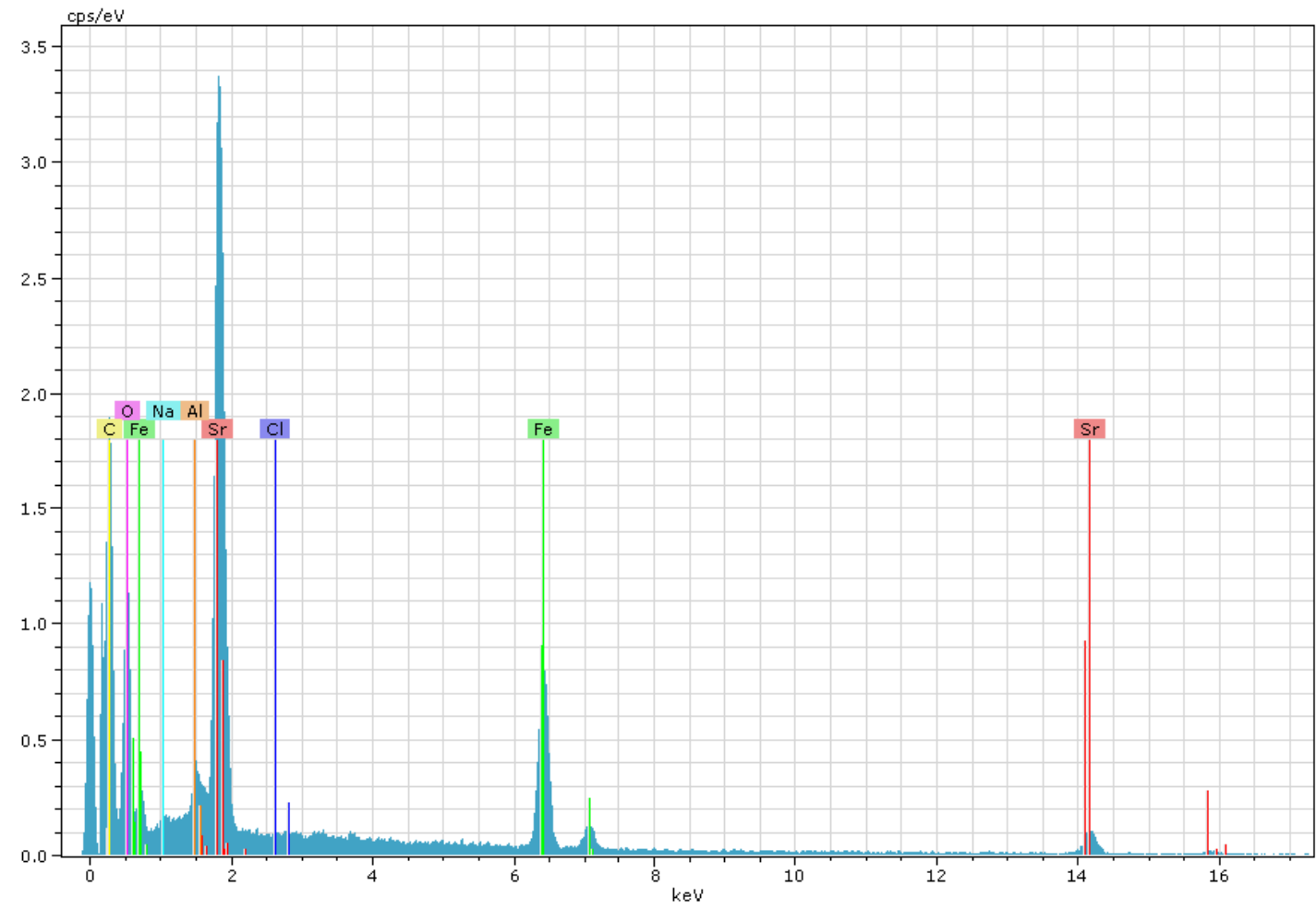

Fig. 40 EDX spectrum of $\mathrm{Sr}_{3} \mathrm{Fe}$-precipitate using $[\mathrm{NaOH}]_{\mathrm{T}}=2 \mathrm{M}$ for the synthesis.

However, the X-ray diffractograms (Fig. 41) of the solid (white) substances precipitated by $2 \mathrm{M}, 5 \mathrm{M}, 10 \mathrm{M}$, or $20 \mathrm{M} \mathrm{NaOH}$ revealed that LDHs did not form even under hyperalkaline conditions. The first reflections were at too high $2 \theta$ values, consequently, the interlayer distance was around $6 \AA$ - smaller than the lower limit typical of LDHs. 


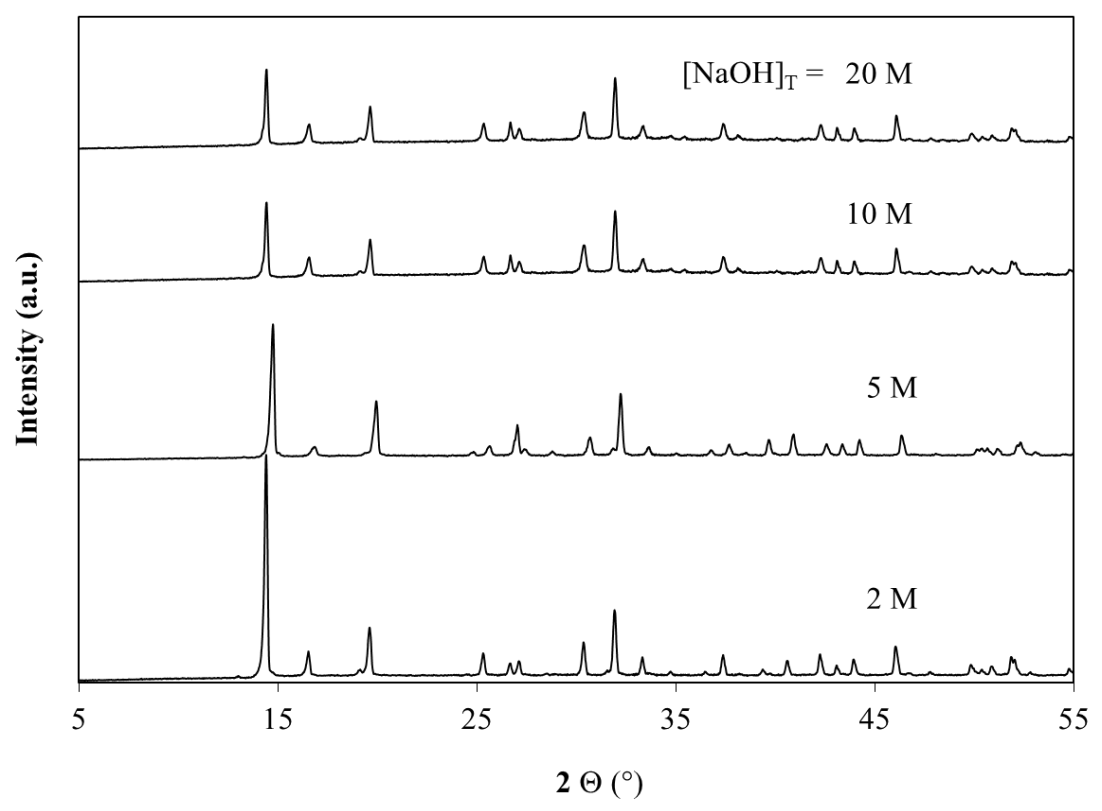

Fig. 41 XRD patterns of the freshly prepared air-dried $\mathrm{Sr}(\mathrm{II}) \mathrm{Fe}(\mathrm{III})$-precipitates obtained at various $[\mathrm{NaOH}]_{\mathrm{T}}-\mathrm{S}$ at $\mathrm{Sr}(\mathrm{II}): \mathrm{Fe}(\mathrm{III})=3: 1$.

The diffractograms were very similar, irrespective of the $\mathrm{NaOH}$ concentration. Thus, it may be concluded that although double hydroxides could be prepared but they were not of layered structure. The detailed structural characterization of the obtained material by synchrotron-based methods is under way and will be part of another $\mathrm{PhD}$ thesis. 


\subsection{Structural characterization of organic-inorganic LDH composites}

For further investigations, the optimal structural details, the insensitivity to altering experimental conditions and the ease of modification are the most necessary properties of an "ideal" LDH. The sensitivity of the $\mathrm{Ba}_{3} \mathrm{Fe}-\mathrm{LDH}$ to humidity does not allow working with diluted aqueous solutions. $\mathrm{Mg}_{3} \mathrm{Fe}-\mathrm{LDH}$ could be a perfect choice, but its brownish color indicates some kind of iron(III)-oxide contamination level. The color of the $\mathrm{Mg}_{4} \mathrm{Fe}$ LDH is much lighter, which means significantly lower concentrations of iron(III)-oxide, however, the net charge of the layers - what is immensely important in the field of intercalation chemistry - is insufficient, because of the larger relative amount of the divalent metal. The degree of crystallinity of the magnesium-containing LDHs is also smaller than that of the white-colored, i.e., practically iron(III)-oxide free calciumcontaining ones. It follows that the ideal LDH to prepare intercalated organic-inorganic composites is the $\mathrm{Ca}_{3} \mathrm{Fe}-\mathrm{LDH}$, which is not air sensitive, stable in aqueous solution, white (or, at least, off-white), and has reasonably large primary particle size.

\subsubsection{Characterization of propenoate derivative-Ca $\mathrm{Ce}-\mathrm{LDH}$ sy $\mathrm{XRD}$}

The success of intercalating the acrylate derivatives can be judged primarily through the analysis of the powder X-ray diffractograms (Figs. 42 and $\mathbf{4 3}$ on pages 54 and 55). Traces $\mathbf{a}, \mathbf{b}$ and $\mathbf{c}$ in these figures are the diffractograms of the pristine $\mathrm{Ca}_{3} \mathrm{Fe}-\mathrm{LDH}$, the sodium salt of the organic guest anions and the organic-inorganic hybrids, respectively. The diffractograms strongly suggest that the organic compounds were successfully intercalated into the interlayer space of $\mathrm{Ca}_{3} \mathrm{Fe}-\mathrm{LDH}$ in their anionic forms, to form propenoate derivative- $\mathrm{Ca}_{3} \mathrm{Fe}-\mathrm{LDH}$ nanocomposites. The interlayer spacing was calculated from the position of the (003) reflection, as usual. This reflection is significantly shifted in traces c, relative to trace a towards the lower $2 \Theta$ values, which unequivocally indicates an increase in basal spacing $[d(003)]$. The $d(003)$ value for the pristine $\mathrm{Ca}_{3} \mathrm{Fe}-\mathrm{LDH}$ is 0.77 $\mathrm{nm}$, while those of the intercalated ones are shown in Table 5. Data in the table reveal that when propenoate derivative was intercalated in a $\mathrm{Ca}_{3} \mathrm{Fe}-\mathrm{LDH}$, in most cases the basal spacing significantly increased relative to that of pristine $\mathrm{Ca}_{3} \mathrm{Fe}-\mathrm{LDH}$ (in which the charge of the layers is compensated by $\mathrm{OH}^{-} / \mathrm{Cl}^{-}$ions). 
The basal spacing of $E$-3-phenylpropenoate- $\mathrm{Ca}_{3} \mathrm{Fe}-\mathrm{LDH}$ composite was found to be $2.07 \mathrm{~nm}$. This value is significantly larger than the $1.80 \mathrm{~nm}$ basal spacing previously published for E-3-phenylpropenoate- $\mathrm{Zn}_{2} \mathrm{Al}-\mathrm{LDH}$ [129]. The difference between the sizes of the metal ions building up the layers is not expected to cause such an increase. Therefore, the arrangements of the organic anions in the gallery space of the two composites must be different.

For the $\mathrm{Ca}_{3} \mathrm{Fe}-\mathrm{LDH}$ composites with $E$-3(4'-chlorobenzoyl)propenoate and $E$-2cyano-3(4'-hydroxyphenyl)propenoate multiple reflections were observed at low angles. The most possible explanation is the variability in the arrangements of the organic anions among the layers of the $\mathrm{LDH}$.

Upon intercalating E-2,3-di-methylpropenoate and E-3(4'-imidazolyl)propenoate, no changes in the positions of the (003) reflections were observed. Two possible explanations may account for these experimental results. Either there was no intercalation or the dimensions of the anions allow an arrangement in the gallery space of LDH that does not cause appreciable change in the basal distance. This issue and the possible arrangement of the organic molecules in the gallery space of LDHs will be discussed in the following chapters. 
I.

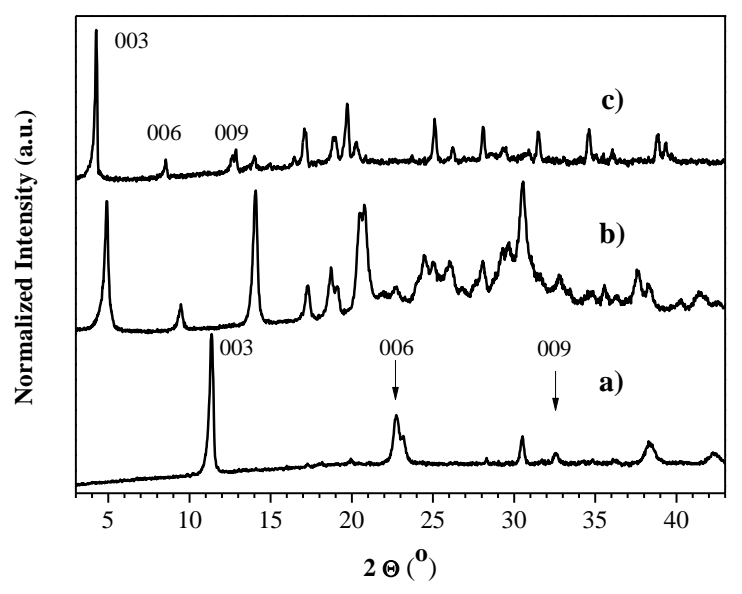

III.

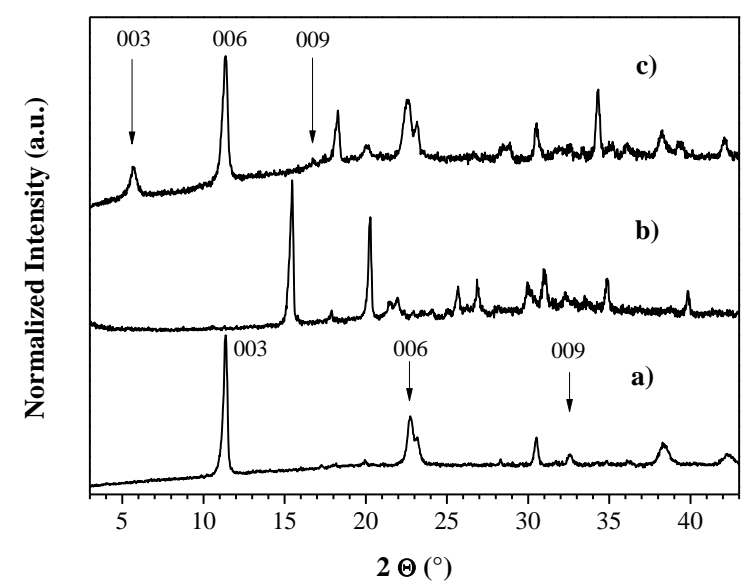

II.

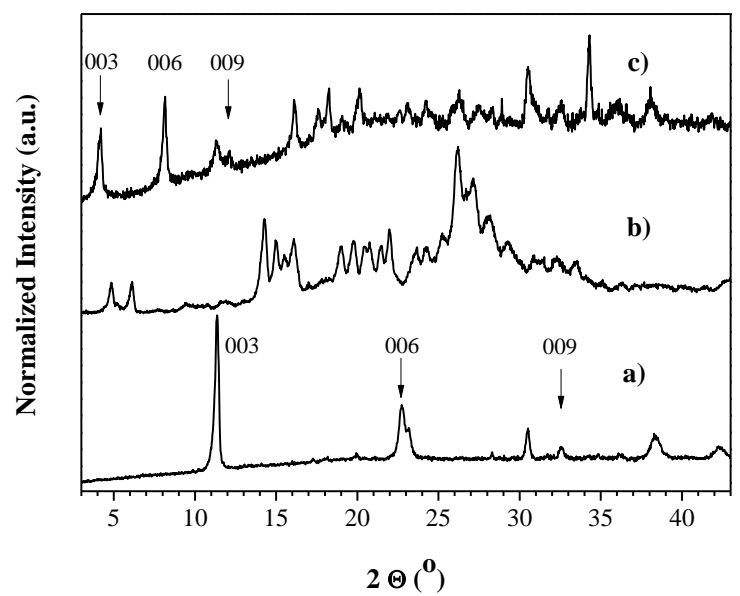

IV.

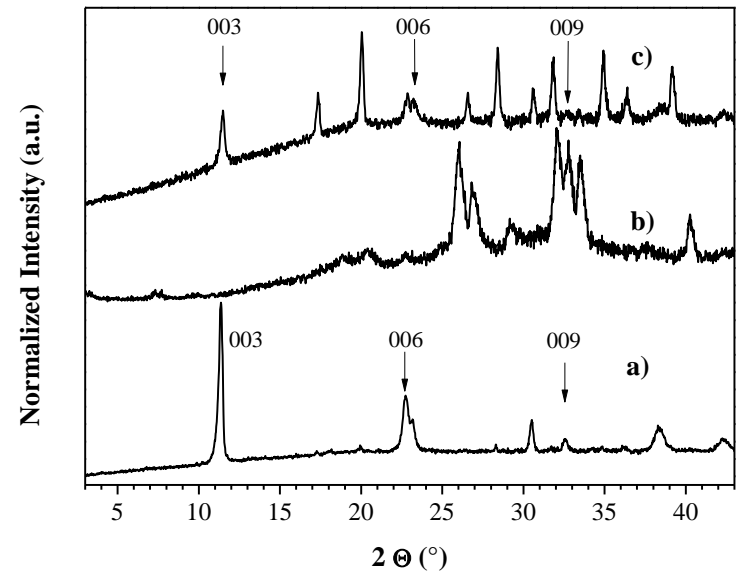

Fig. $42 \mathrm{X}$-ray diffractograms of a) $\mathrm{Ca}_{3} \mathrm{Fe}-\mathrm{LDH}$; b) Na-salt of the propenoate derivative; c) propenoate derivative-Ca $\mathrm{Fe}-\mathrm{LDH}$. I. E-3-phenylpropenoate; II. E-3(4'-nitrophenyl)propenoate; III. E-3(2'-thienyl)propenoate; IV . E-2,3-dimethylpropenoate. 

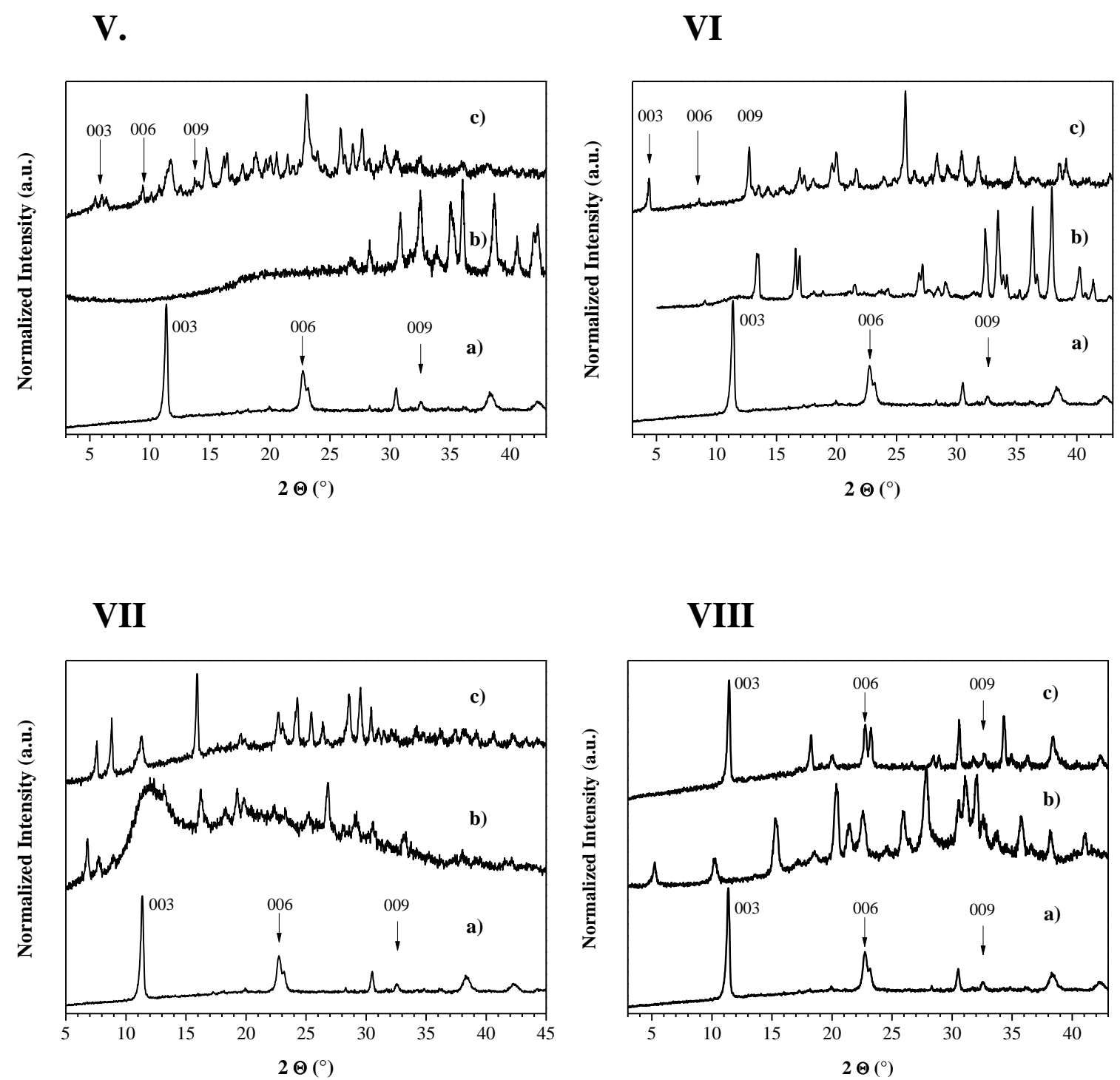

Fig. $43 \mathrm{X}$-ray diffractograms of a) $\mathrm{Ca}_{3} \mathrm{Fe}-\mathrm{LDH}$; b) Na-salt of the propenoate derivative; c) propenoate derivative-Ca $3 \mathrm{Fe}-\mathrm{LDH}$. V. E-3(4'-chlorobenzoyl)propenoate; VI. $E-3\left(2^{\prime}, 5^{\prime}-\right.$ difluorophenyl)propenoate; VII. E-2-cyano-3(4'-hydroxyphenyl)propenoate; VIII. E-3(4'imidazolyl)propenoate. 
5.2.2. Characterization of propenoate derivative-Ca $\mathrm{Ce}$-LDHs by scanning electron microscopy

The SEM images of the pure organic salts are seen in Figs. 43-45/a, while those of their organic-inorganic nanohybrids are shown in Figs. 43-45/b. In the latter ones lamellar structures are observed, i.e., the atomic level structure is reflected in the morphology of the substances.

Striking differences are seen between the SEM images of the organic salts and those of the organic-inorganic nanohybrids with E-3-phenylpropenoate (Fig. 43/I), E-4'nitrophenylpropenoate (Fig. 43/II), E-2,3-dimethylpropenoate (Fig. 43/IV) and E-3(4'imidazolyl)propenoate (Fig. 43/VIII). Needle-like crystals or crystal forms dissimilar to that of the pristine LDH are typical for these organic salts and these features disappear after intercalation. It is clear that the organic anions were not simply adsorbed on the outer surface of the $\mathrm{LDH}$, and, for E-3-phenylpropenoate and $E$-3(4'-nitrophenyl)propenoate intercalation, together with XRD data, it further proves the success of intercalation. Note, however, that for the dimethyl and imidazolyl derivatives, the diffractograms did not show any differences between the pristine and (presumably) intercalated $\mathrm{Ca}_{3} \mathrm{Fe}-\mathrm{LDH}$. The lack of the crystalline forms of the organic salts in the SEM images, unfortunately, still not enough to decide unambiguously, whether intercalation was successful or not. For this, further experiments were needed (see later).

Differences between the images of $E-3\left(2^{\prime}\right.$-thienyl)propenoate (Fig. 43/III), E-3(4'chlorobenzoyl)propenoate (Fig. 43/V), E-3(2',5'-difluorophenyl)propenoate (Fig. 43/VI), E-2-cyano-3(4'-hydroxyphenyl)propenoate (Fig. 43/VII) salts and their intercalated forms are not so obvious as those for the other salts. Fortunately, the XRD patterns of the nanohybrids having these anions as guests provide enough proof for the success of the intercalation. 
I.
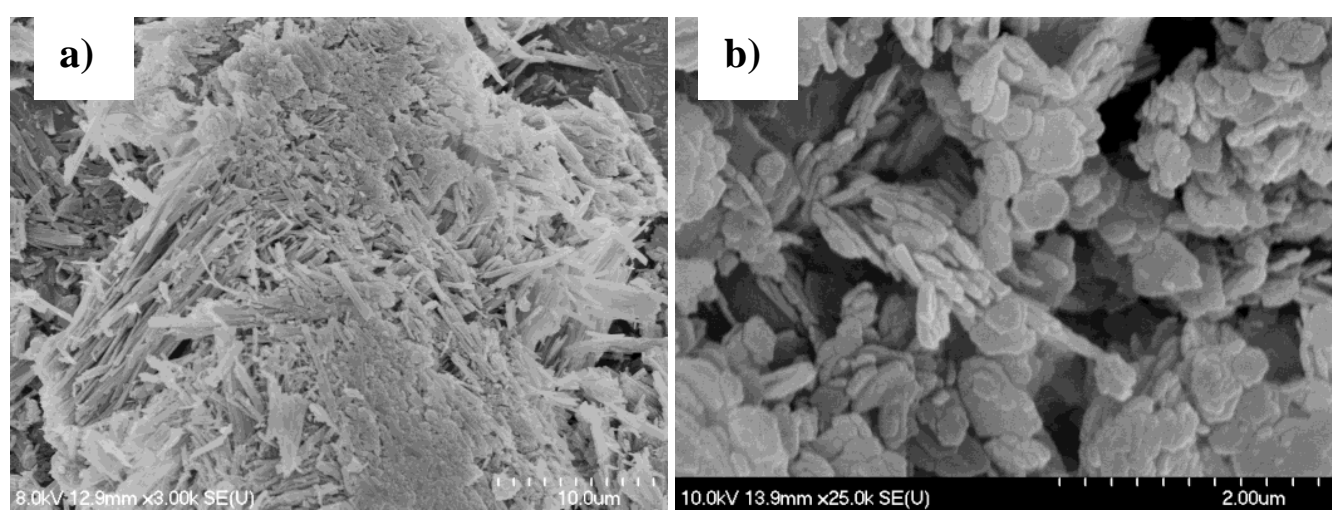

II.
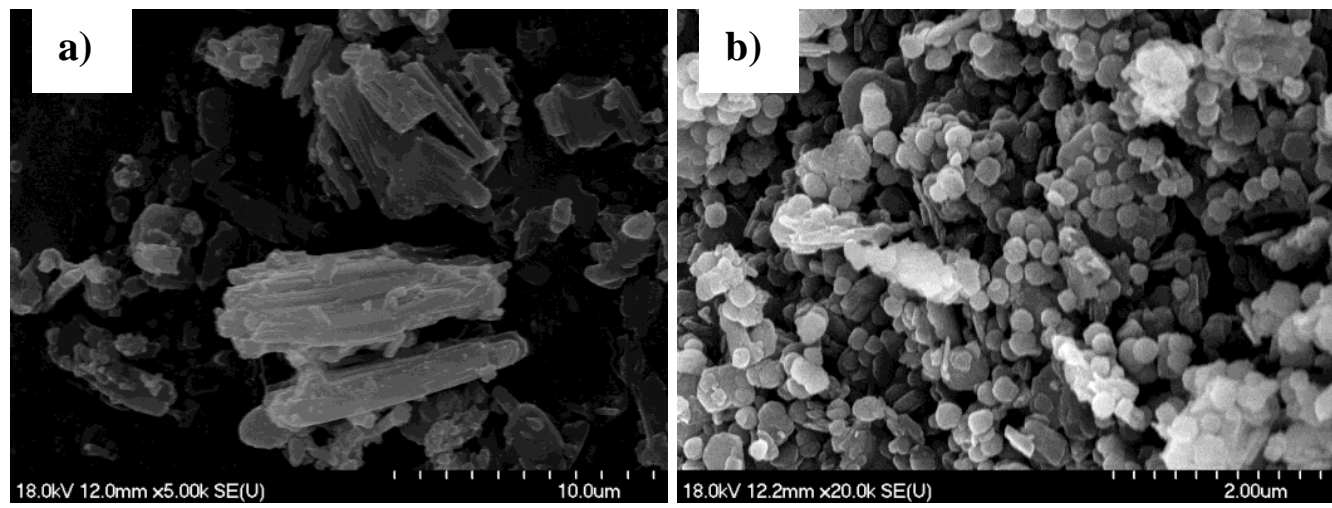

III.
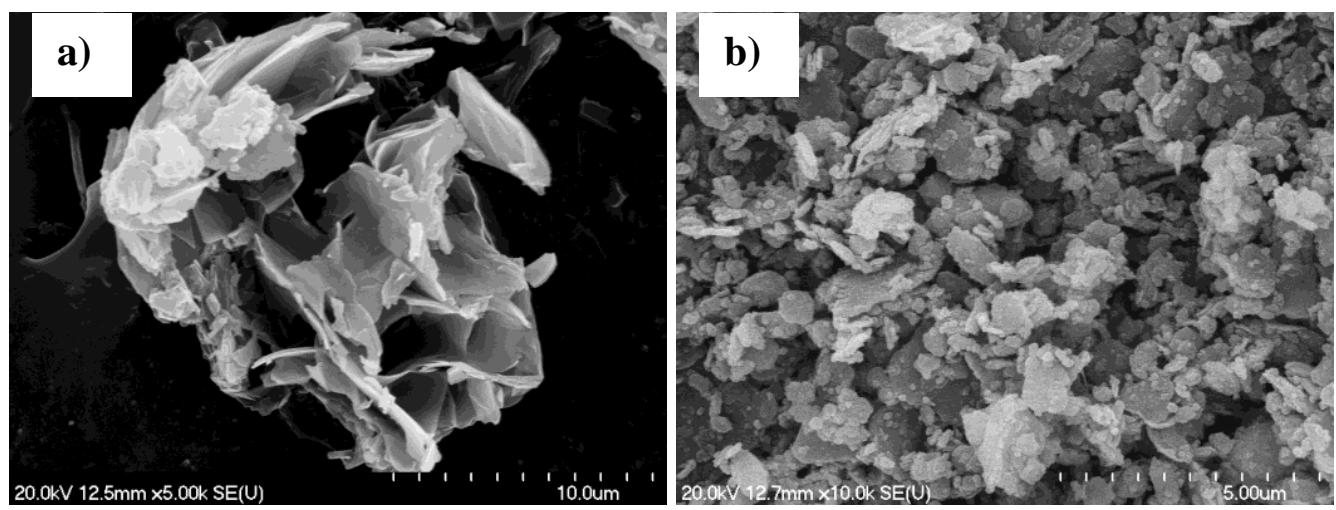

Fig. 43 SEM images of the organic-inorganic nanohybrids: a) Na-salt of propenoate derivative; b) propenoate derivative- $\mathrm{Ca}_{3} \mathrm{Fe}-\mathrm{LDH}$ : I. E-3-phenylpropenoate; II. E-3(4'nitrophenyl)propenoate; III. $E-3\left(2^{\prime}\right.$-thienyl)propenoate (magnifications: 3,000, 5,000, $10,000,20,000$ and 25,000). 
IV.
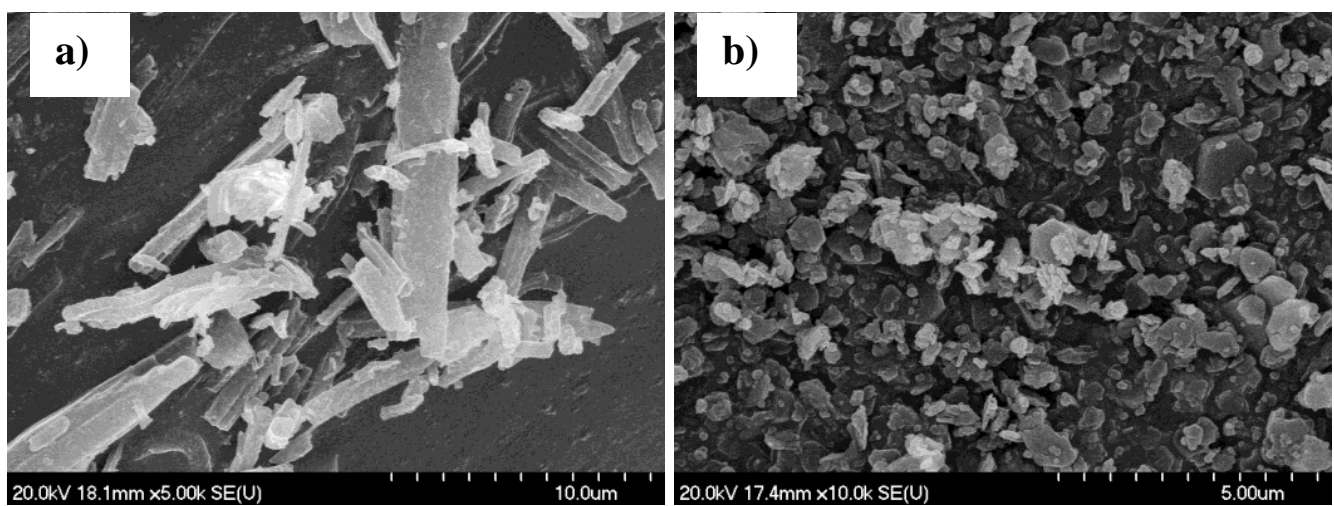

V.
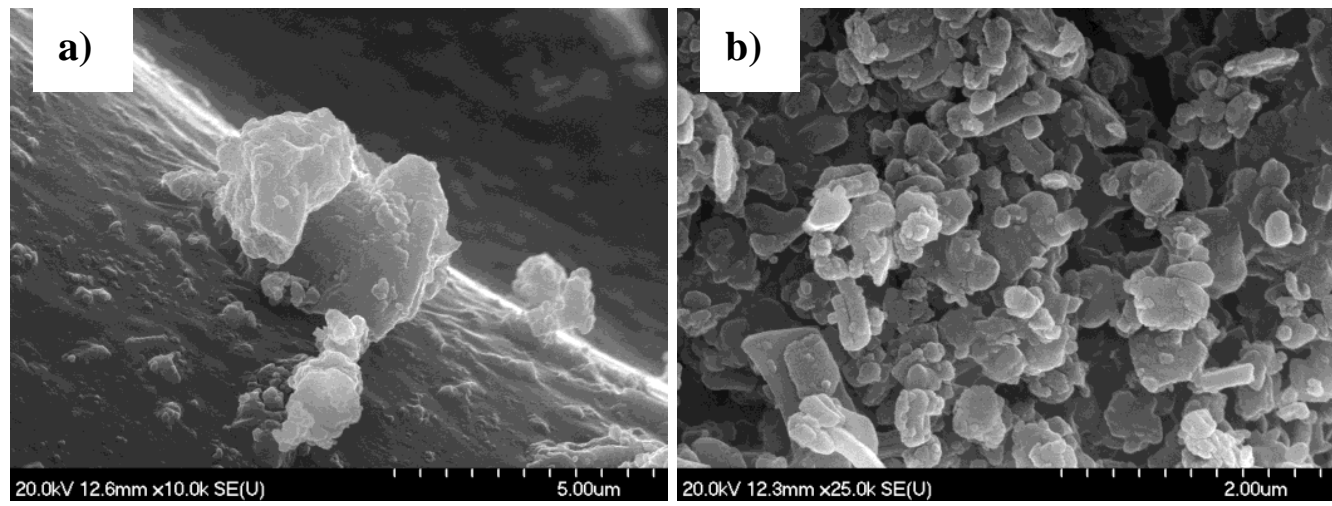

VI.
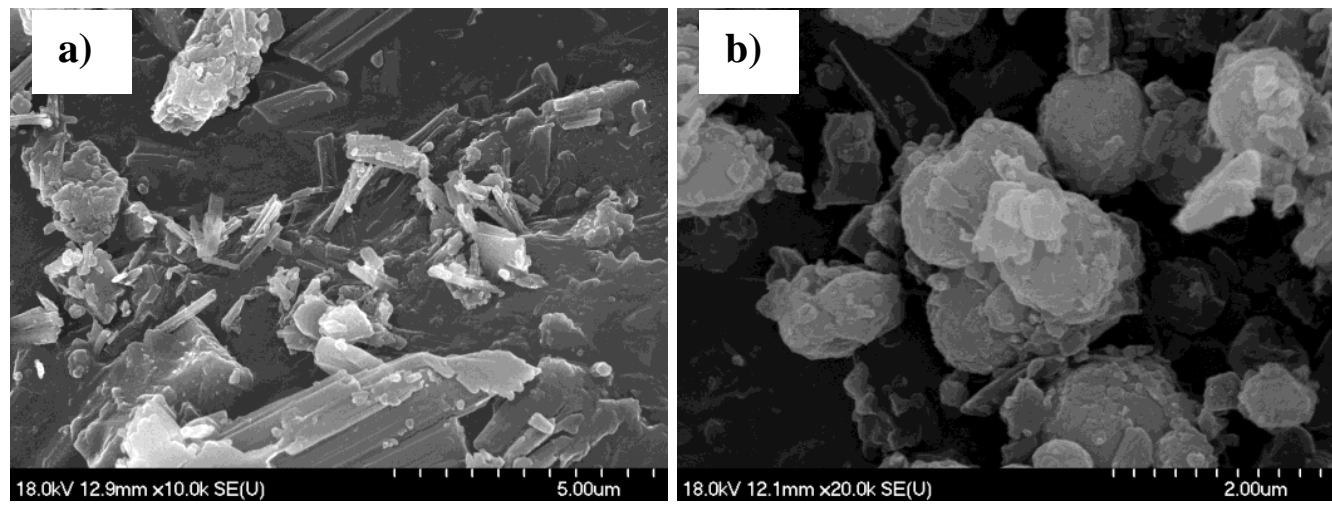

Fig. 44 The SEM images of the organic-inorganic nanohybrids: a) Na-salt of propenoate derivative; b) propenoate derivative-Ca $\mathrm{Ca}_{3} \mathrm{Fe}-\mathrm{LDH}$ : IV. E-2,3-dimethylpropenoate; V. E3(4'-chlorobenzoyl)propenoate; VI. E-3(2',5'-difluorophenyl)propenoate (magnifications: $5,000,10,000,20,000$ and 25,000). 
VII.
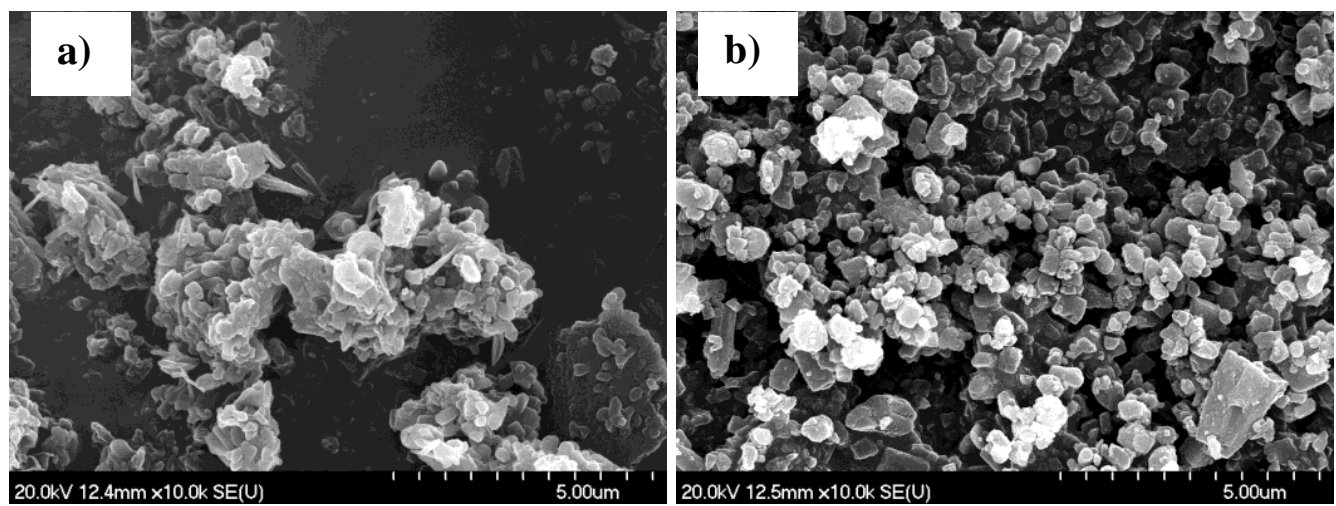

VIII.
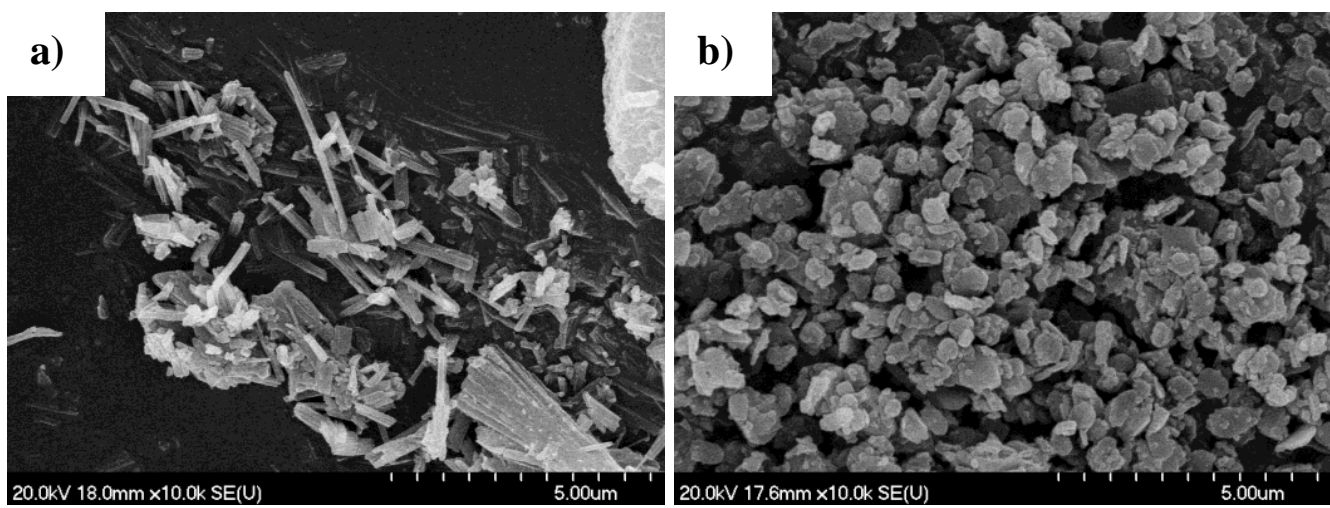

Fig. 45 SEM images of the organic-inorganic nanohybrids: a) Na-salt of propenoate derivative; b) propenoate derivative- $\mathrm{Ca}_{3} \mathrm{Fe}-\mathrm{LDH}$ : VII. E-2-cyano-3(4'-hydroxyphenyl)propenoate; VIII. E-3(4'-imidazolyl)propenoate (magnification: 10,000). 


\subsubsection{Characterization of propenoate derivative-Ca $\mathrm{Ca}$-LDHs by energy dispersive $\mathrm{X}$-ray}

analysis (coupled to scanning electron microscopy)

The combination of SEM-EDX measurements allowed the preparation of the elemental maps of the intercalated materials (Figs. 46-48). The SEM images were made at 15,000 or 20,000 magnifications.

The $\mathrm{Ca}-\mathrm{Fe}$ maps verify that we have double hydroxides in our hands indeed, not only, because the metals ions are evenly distributed in the sample, but also, because there is no $\mathrm{Fe}$ or $\mathrm{Ca}$ accumulation, i.e., segregated individual oxides were not formed in appreciable amounts. In other words, the hydroxides were not physical mixtures of Fe- and Ca-hydroxides. The $\mathrm{C}-\mathrm{O}, \mathrm{C}-\mathrm{F}, \mathrm{C}-\mathrm{Cl}, \mathrm{C}-\mathrm{N}$ and $\mathrm{C}-\mathrm{S}$ maps indicate that the respective organic materials were also evenly distributed in the samples. For the substances we already have enough proofs for successful intercalation the SEM-EDX elemental map is an added bonus, however, for those having E-2,3-dimethylpropenoate or E-3(4'imidazolyl)propenoate as guests, they provide the final proof, i.e., now, we can safely state that each of our acrylate samples could be introduced in-between the layers of CaFe-LDH.

I.
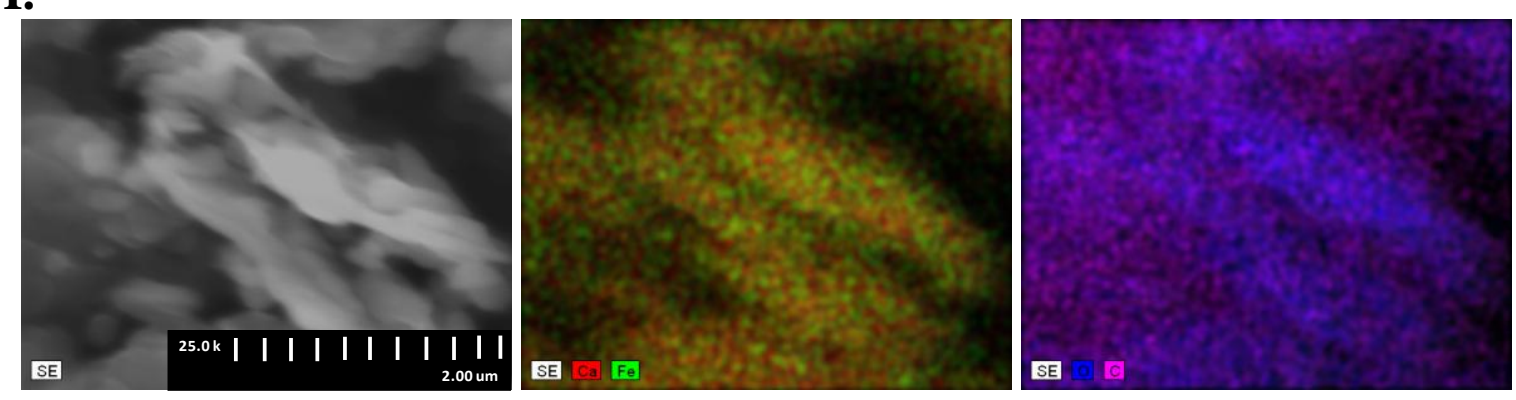

\section{II.}
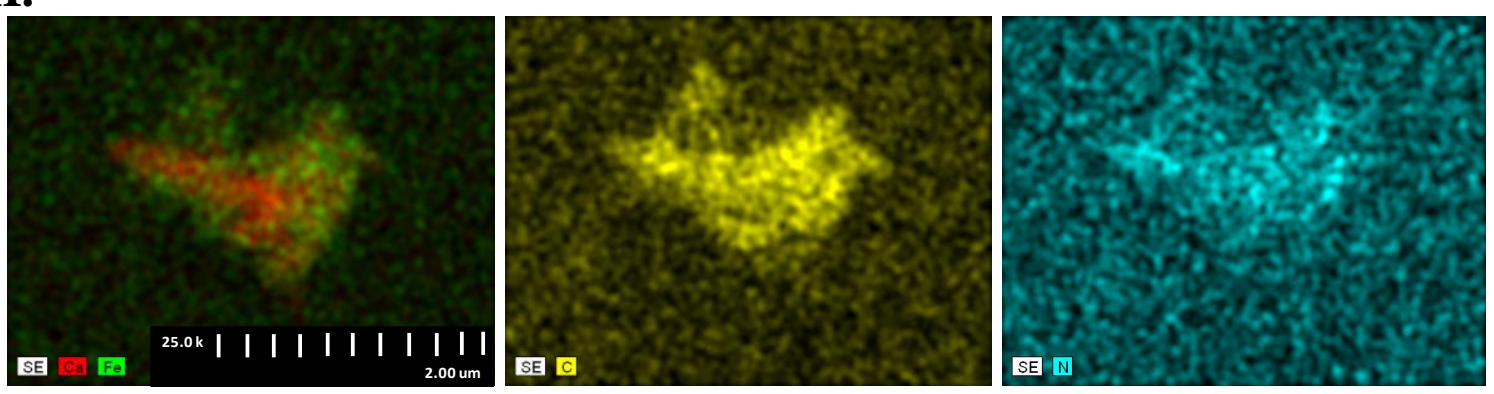

Fig. 46 Elemental maps of propenoate derivative- $\mathrm{Ca}_{3} \mathrm{Fe}-\mathrm{LDH}$ samples obtained on SEM images at magnification of 25,000. I. E-3-phenylpropenoate; II. E-3(4'-nitrophenyl)propenoate. 


\section{III.}
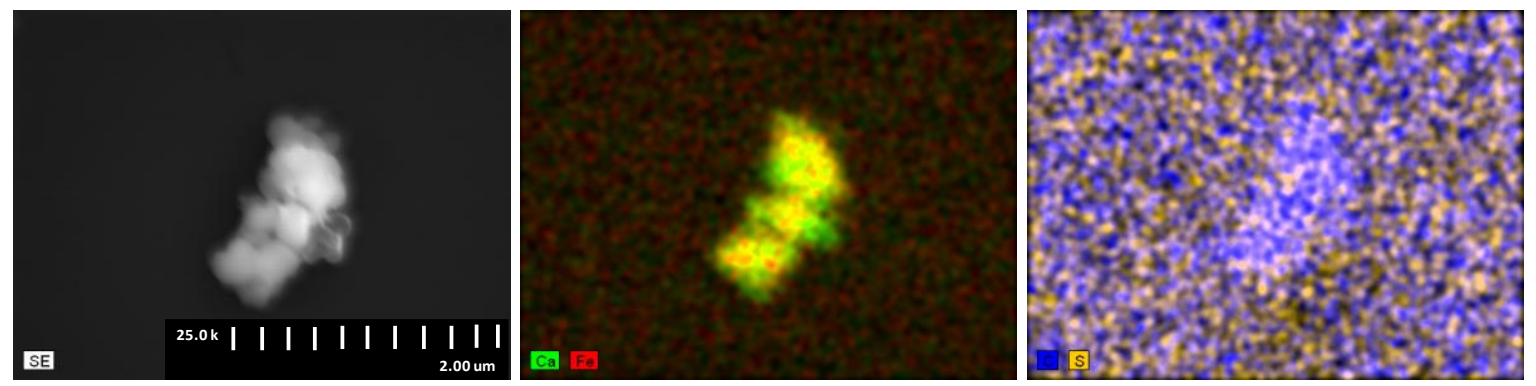

IV.
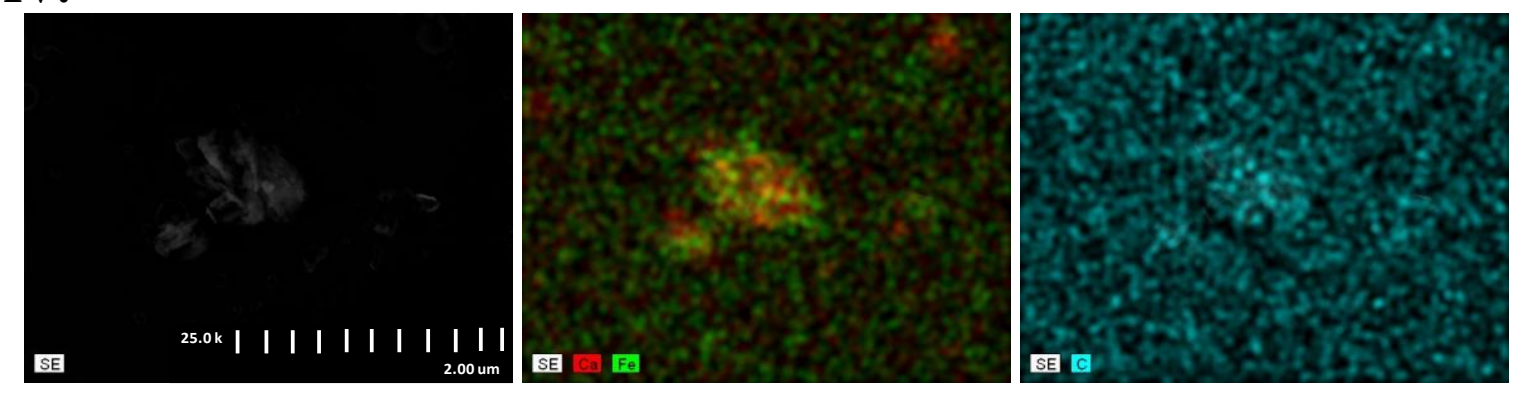

V.
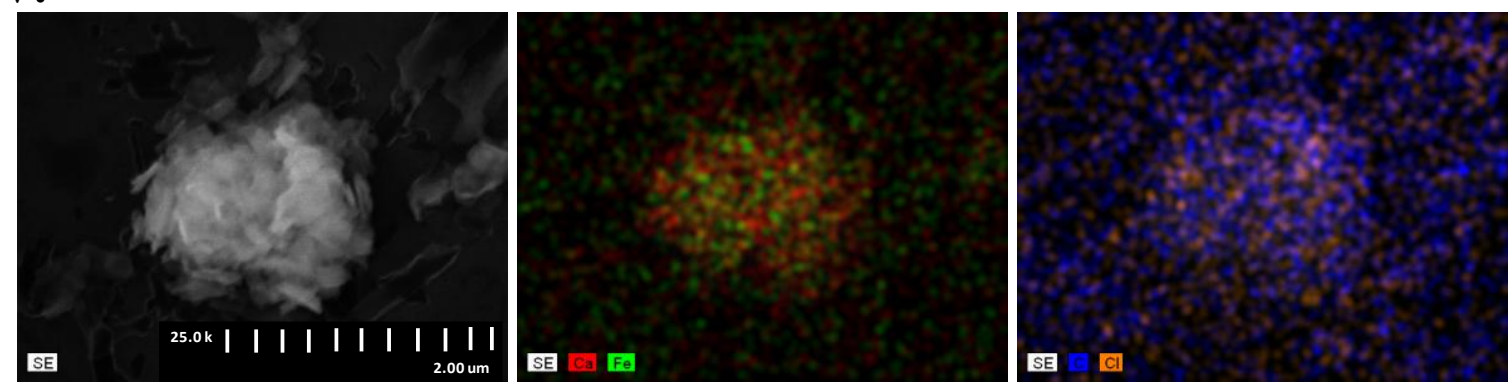

VI.
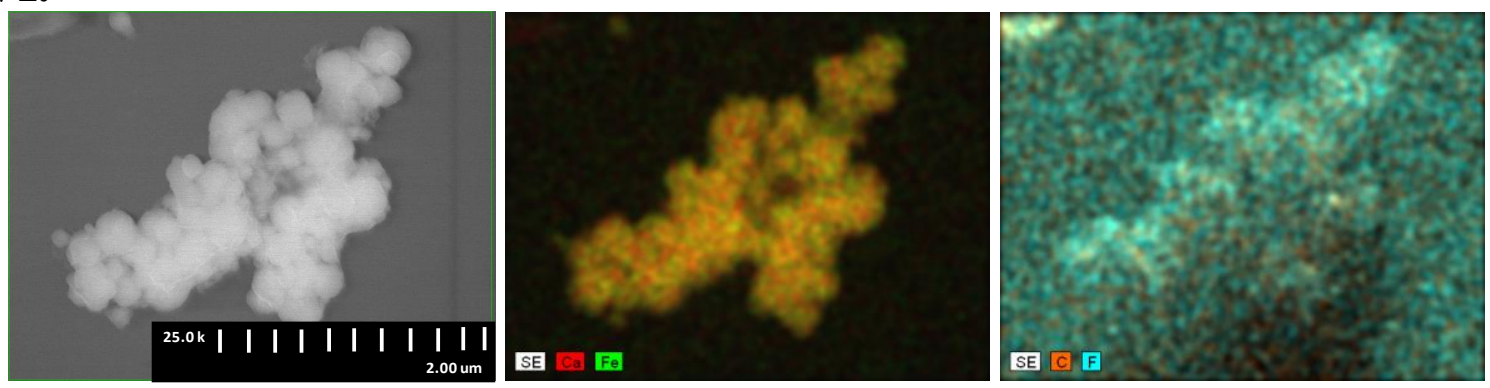

Fig. 47 Elemental maps of propenoate derivative-Ca $\mathrm{Ca}_{3} \mathrm{Fe}-\mathrm{LDH}$ samples obtained on SEM images at magnification of 25,000 . III. $E-3\left(2^{\prime}\right.$-thienyl)propenoate; IV. $E-2,3-$ dimethylpropenoate; V. $\quad E-3\left(4^{\prime}\right.$-chlorobenzoyl)propenoate; VI. $\quad E-3\left(2^{\prime}, 5^{\prime}\right.$-difluorophenyl)propenoate. 


\section{VII.}
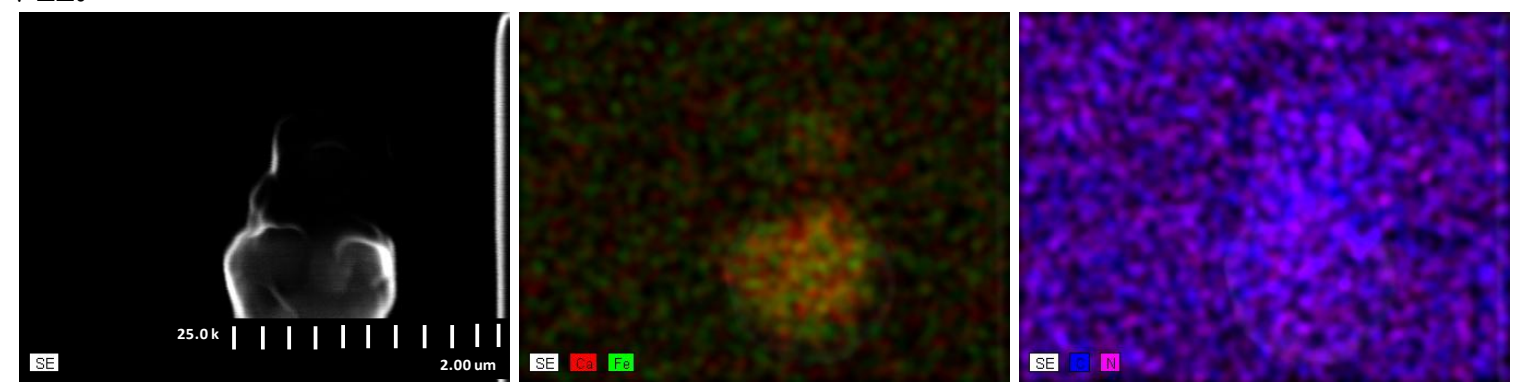

\section{VIII.}
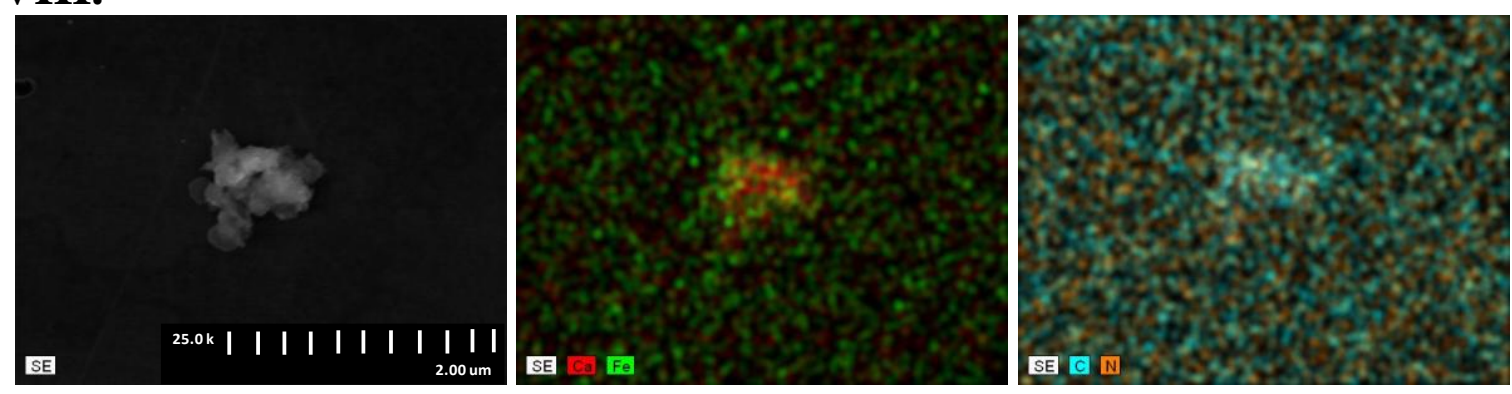

Fig. 48 Elemental maps of propenoate derivative- $\mathrm{Ca}_{3} \mathrm{Fe}-\mathrm{LDH}$ samples obtained on SEM images at magnification of 25,000. VII. E-2-cyano-3(4'-hydroxyphenyl)propenoate; VIII. E-3(4'-imidazolyl)propenoate.

\subsubsection{Characterization of propenoate derivative-Ca $\mathrm{Ca}$ - $L D H$ s by FT-IR spectroscopy}

The IR spectra of the samples (organic salts, the pristine $\mathrm{Ca}_{3} \mathrm{Fe}-\mathrm{LDH}$ and their nanohybrids) were also taken and compared. The main goals were to see if there was organic matter in the sample on one hand and if it is the acrylate derivative remained intact on the other hand, i.e., no undesired chemical reactions (e.g. degradation) took place during the preparation. To arrive at a conclusion the difference spectra of the intercalated and the neat LDHs were registered and compared to the spectra of the respective acrylate derivative ions (Figs. 49 and 50).

The difference spectra and those of the corresponding spectra of the acrylate ions show very close resemblance in all cases, therefore, it can be stated that the LDH samples contained organic compounds and they were the intact acrylate ions. Most bands completely coincide, except those typical of the carboxylate stretching vibrations. They are indicated in the figures and assigned as $v_{\text {asym }}$ and $v_{\text {sym }}$, situating around $\sim 1550 \mathrm{~cm}^{-1}$ and $\sim 1400 \mathrm{~cm}^{-1}$, respectively [130]. In the difference spectra they are somewhat displaced, indicating interaction between the negatively charged carboxylate moieties and the positively charged layers of the LDH. For E-2-cyano-3(4'-hydroxyphenyl)propenoate$\mathrm{Ca}_{3} \mathrm{Fe}-\mathrm{LDH}$, the position of the $\mathrm{N} \equiv \mathrm{C}$ peak at $2197 \mathrm{~cm}^{-1}$ also changed relative to that of the 
pure compound. This indicates variability in the arrangements of the molecules already shown by the multiple reflections in the XRD spectrum at low $2 \Theta$ values (Ch. 5.2.1.). The fact that the positions of the other bands do not change is a likely indication that further interactions between the guest anion and the host material do not take place.

Further analysis of the spectra of the acrylate derivatives and their intercalated forms will be presented in the Ch. 6.3.

I.

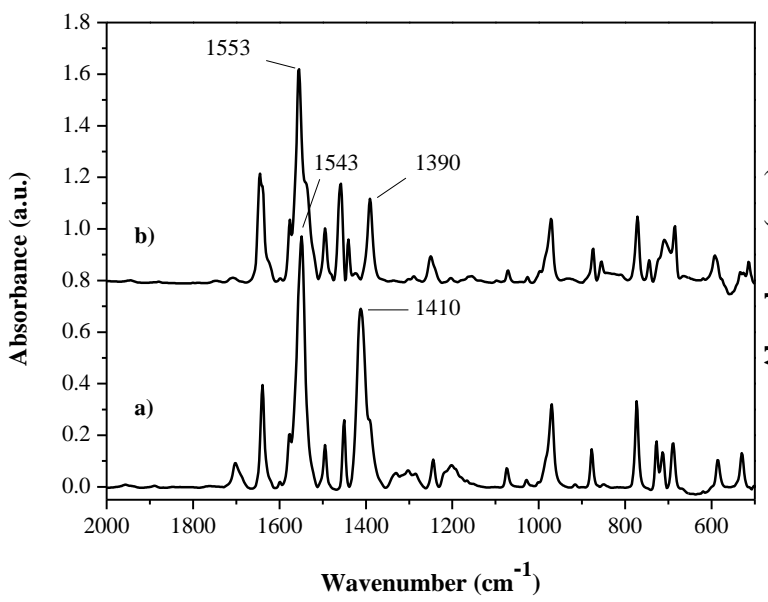

III.

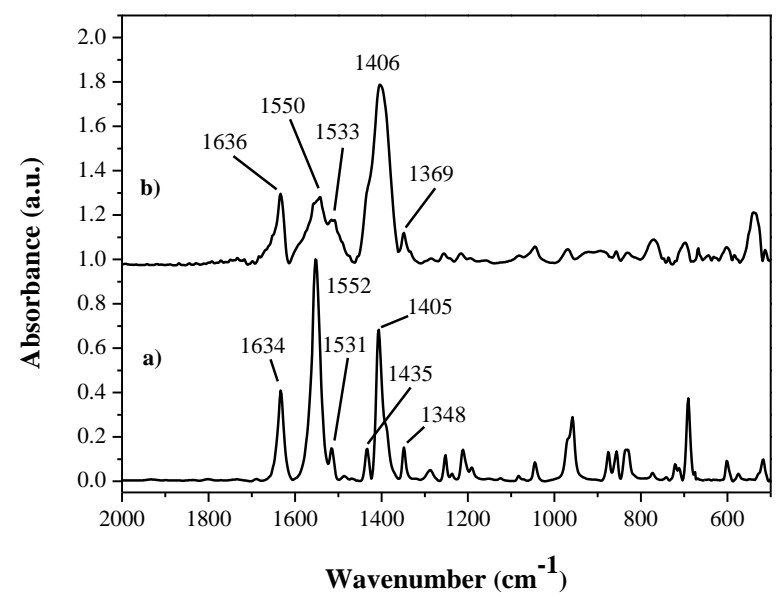

II.

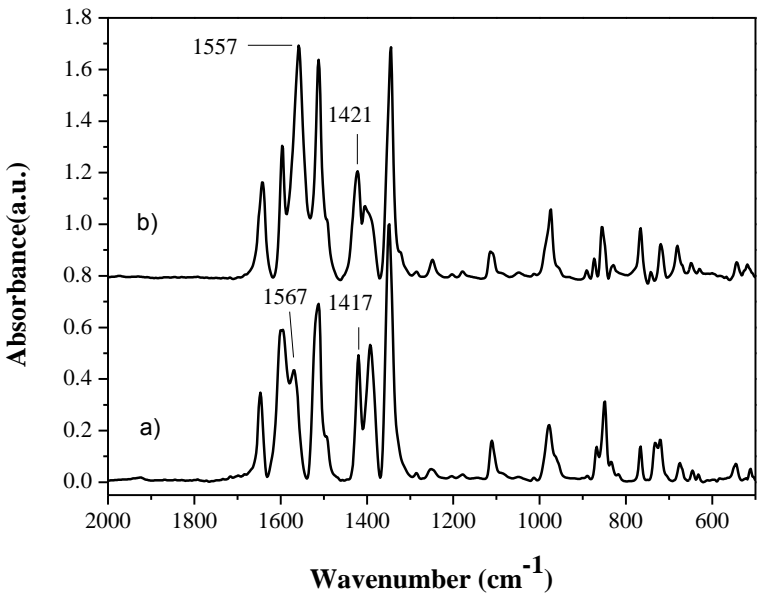

IV.

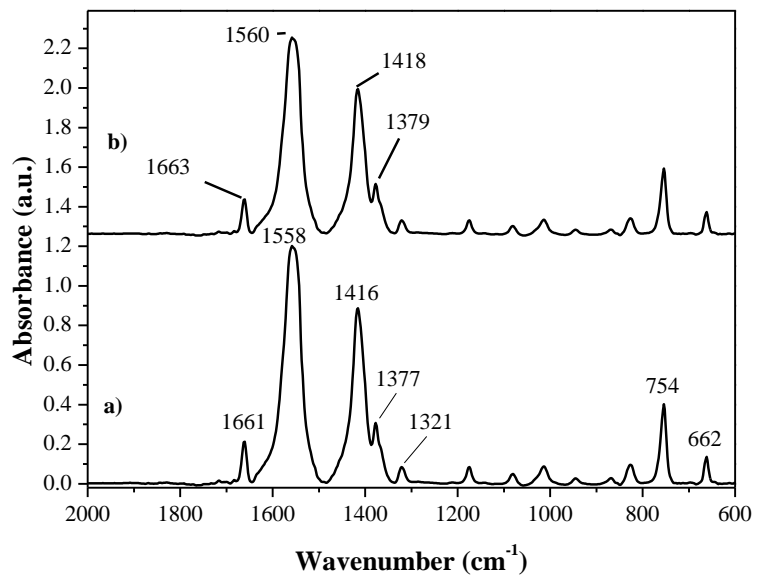

Fig. 49 The FT-IR spectra of the Na-salt of propenoate derivatives and the difference spectra of propenoate derivative- $\mathrm{Ca}_{3} \mathrm{Fe}-\mathrm{LDH}$ samples; a) the neat sodium salt, b) the difference spectrum of the organic-inorganic hybrid. I. E-3-phenylpropenoate; II. E-3(4'nitrophenyl)propenoate; III. $E$-3(2'-thienyl)propenoate; IV. E-2,3-dimethylpropenoate. 

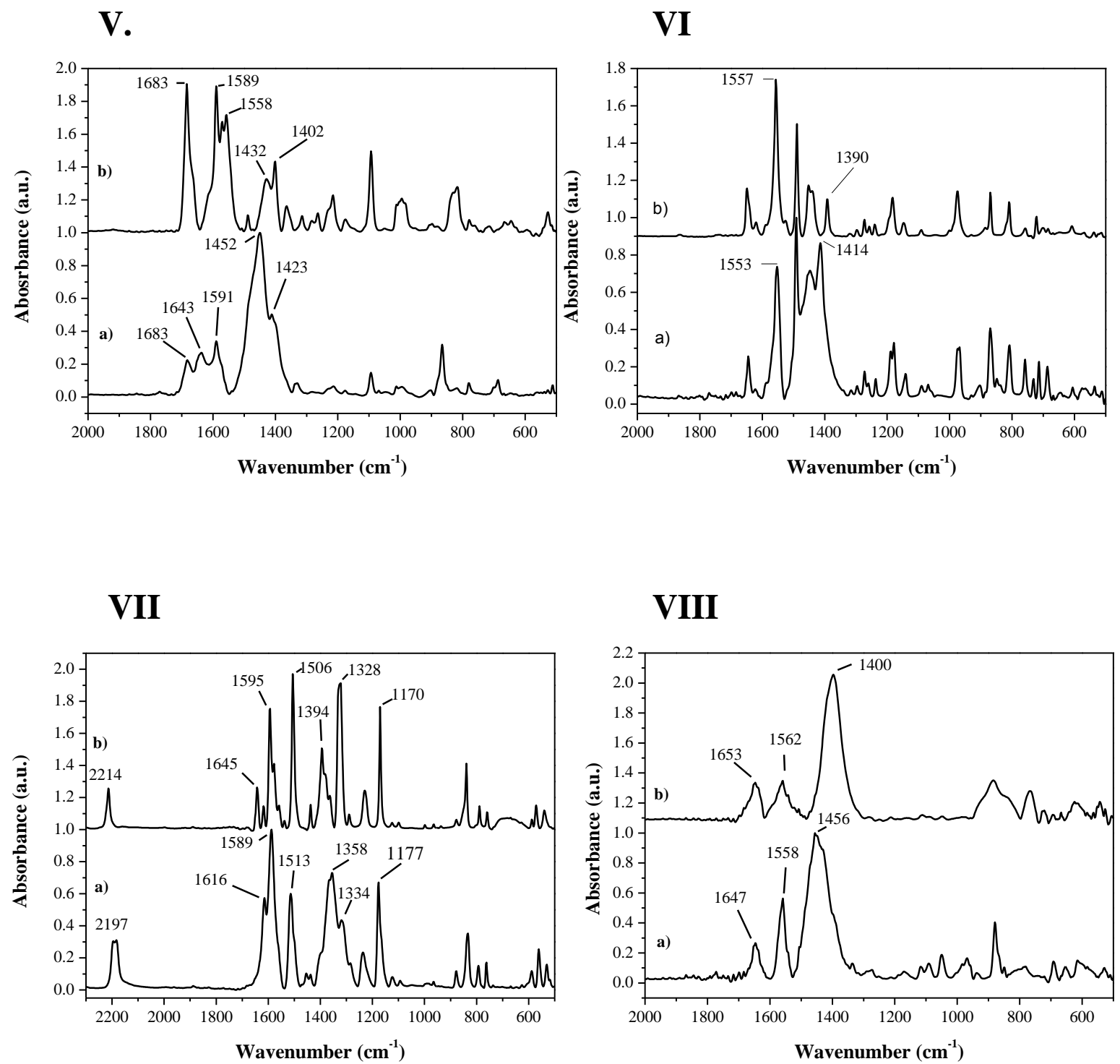

Fig. 50 The FT-IR spectra of the Na-salt of propenoate derivatives and the difference spectra of propenoate derivative- $\mathrm{Ca}_{3} \mathrm{Fe}-\mathrm{LDH}$ samples; a) the neat sodium salt, b) the difference spectrum of the organic-inorganic hybrid. V. E-3(4'-chlorobenzoyl)propenoate; VI. E-3(2',5'-difluorophenyl)propenoate; VII. E-2-cyano-3(4'-hydroxyphenyl)propenoate; VIII. $E$-3(4'-imidazolyl)propenoate. 
5.2.5. Molecular models of the propenoate derivative-CaFe-LDH organic-inorganic nanohybrids

Computer simulations of the intercalated LDHs and, thus, the exact arrangements of the organic molecules are complicated and are beyond the limits of our computer resources. Therefore, the layers are not modeled, the interlayer spacing is calculated on the basis of experimental findings and literature data, and the dimensions of the intercalated anions are only computed from the parallelepiped that includes the acrylate anion, whose structure is optimized by the PM3 semiempirical method.

The interlayer distance data were calculated from interlayer spacing values $[d(003)]$ and the approximate thickness of the layer $(0.48 \mathrm{~nm})$ and are shown in shown in Table 6, along with the dimensions of the anions, optimized by the PM3 semiempirical method. On the basis of these data approximate arrangement of the organic molecules in the gallery space may be suggested.

Organic molecules can be located in the gallery space in various ways. Their sizes and functional groups determine their ideal arrangement. The organic molecules may be positioned in the interlayer space as mono- or multimolecular layers. An important requirement must be met, however, the negatively charged group of the anion must be oriented towards the positively charged LDH layer. In multilayer arrangement, various interactions like $\mathrm{C}-\mathrm{H} . . . \pi$ and/or $\pi$... $\pi$ close contacts may keep the layers together [129].

Table 6 The basal spacing values and the interlayer distances of LDHs intercalated with various propenoate derivatives and the calculated dimensions of the organic anions.

\begin{tabular}{lccc}
\hline \multicolumn{1}{c}{ Propenoate derivatives } & $\begin{array}{c}\text { basal spacing } \\
d(003)(\mathrm{nm})\end{array}$ & $\begin{array}{c}\text { dimensions of the } \\
\text { anion }(\mathrm{nm})\end{array}$ & $\begin{array}{c}\text { interlayer } \\
\text { distance }(\mathrm{nm})\end{array}$ \\
\hline E-3-phenyl & 2.07 & $0.47 \times 0.02 \times 0.85$ & 1.59 \\
$E$-3(4'-nitrophenyl) & 2.48 & $0.46 \times 0.04 \times 0.96$ & 1.94 \\
$E-3\left(2^{\prime}\right.$-thienyl) & 1.57 & $0.39 \times 0.29 \times 0.74$ & 1.09 \\
$E-2,3$-dimethyl & 0.77 & $0.40 \times 0.21 \times 0.50$ & 0.29 \\
$E-3(4$ '-chlorobenzoyl) & $1.62 / 1.47 / 1.38$ & $0.49 \times 0.21 \times 0.96$ & $1.14 / 0.99 / 0.90$ \\
$E-3\left(2^{\prime}, 5\right.$ '-difluorophenyl) & 2.02 & $0.47 \times 0.20 \times 0.86$ & 1.54 \\
$\begin{array}{l}\text { E-2-cyano-3(4'-hydroxy- } \\
\text { phenyl) }\end{array}$ & $1.17 / 1.00$ & $0.42 \times 0.38 \times 0.88$ & $0.69 / 0.52$ \\
$E-3(4$ '-imidazolyl) & 0.78 & $0.36 \times 0.22 \times 0.76$ & 0.30 \\
\hline
\end{tabular}


The interlayer distance in $E$-3-phenylpropenoate- $\mathrm{Ca}_{3} \mathrm{Fe}-\mathrm{LDH}$ is $1.59 \mathrm{~nm}$. A comparison with the dimensions of the organic anion suggests a bilayer arrangement, in which the anions are tilted with respect to the layers (Fig. 51). It is certain that water molecules are also present in the gallery space and they are associated with the layers [53,55]. Although we do not know the thickness of this water layer, the overall picture is not influenced much, the tilting angle may be influenced and/or the phenyl rings of the opposite layers may move towards each other resulting in energetically favorable $\mathrm{C}-\mathrm{H} . . . \pi$ and/or $\pi . . \pi$ interactions.

Similarly, a bilayer arrangement can be suggested for the $E-3\left(4^{\prime}\right.$-nitrophenyl)propenoate ion as displayed in Fig. 52.

While the observed basal distance is large enough to accommodate the $E-3\left(4^{\prime}-\right.$ nitrophenyl)propenoate ion between the layers comfortably, for the $E-3\left(2^{\prime}\right.$-thienyl)propenoate $-\mathrm{Ca}_{3} \mathrm{Fe}-\mathrm{LDH}$

$0.85 \mathrm{~nm}$

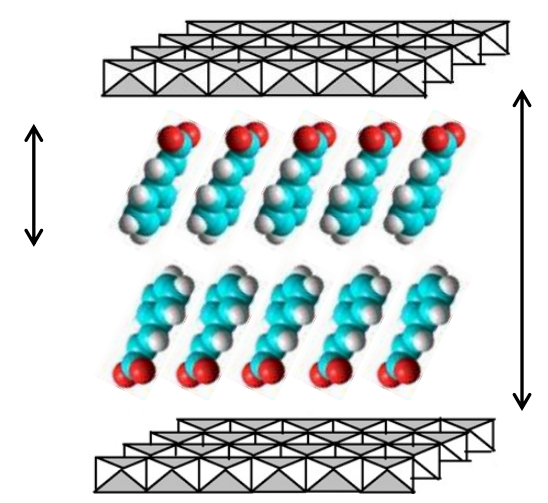

$1.59 \mathrm{~nm}$

Fig. 51 A possible arrangement of acrylate ions in the interlayer space of the $E$-3-phenylpropenoate $-\mathrm{Ca}_{3} \mathrm{Fe}$ LDH hybrid.

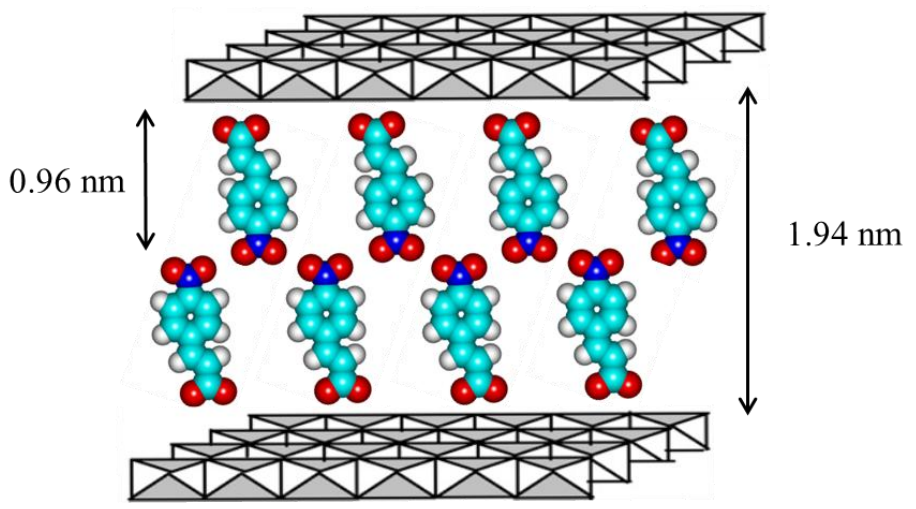

Fig. 52 A possible arrangement of acrylate ions in the interlayer space of the E-3(4'-nitrophenyl)propenoate- $\mathrm{Ca}_{3} \mathrm{Fe}-\mathrm{LDH}$ hybrid.

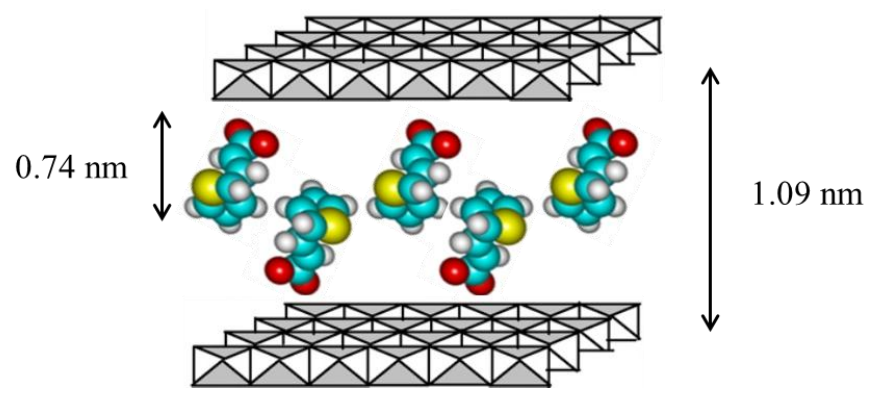

Fig. 53 A possible arrangement of acrylate ions in the interlayer space of the $E-3\left(2^{\prime}\right.$-thienyl)propenoate $-\mathrm{Ca}_{3} \mathrm{Fe}-\mathrm{LDH}$ hybrid. 
hybrid the interlayer space $(1.09 \mathrm{~nm})$ is not sufficient for the organic molecules to form a distinct bilayer structure (Fig. 53). Aromatic rings of organic molecules in the opposite layers may enter into $\mathrm{C}-\mathrm{H} \ldots \pi$ and/or $\pi \ldots \pi$ interaction.

A tilted bilayer arrangement may be envisaged for the intercalated $E-3\left(2^{\prime}, 5^{\prime}\right.$-difluorophenyl)propenoate anions as well with phenyl rings interacting as described previously (Fig. 54). The intercalated organic anions presented so far formed bilayer structure in the gallery space of LDHs, however, interlayer spacing for the remaining ones (E-3(4'-chlorobenzoyl)propenoate and E-2-cyano-3(4'hydroxyphenyl)propenoate) are not large enough to accommodate two layers of anions even if some overlap between the would-be layers are allowed, i.e., for this organic-inorganic hybrids monolayer arrangements are suggested as displayed in Figs. 55 and 56.

Although for the $E-2$ cyano-3(4'-hydroxyphenyl)propenoate- $\mathrm{Ca}_{3} \mathrm{Fe}-\mathrm{LDH}$ hybrid two values for the interlayer spacing $(0.69 \mathrm{~nm}$ and $0.52 \mathrm{~nm}$ ) could be deduced indicating possible variations in the arrangements of the intercalated anions, none of these distances allow bilayer arrangement.

Judged solely on the practically unchanged basal

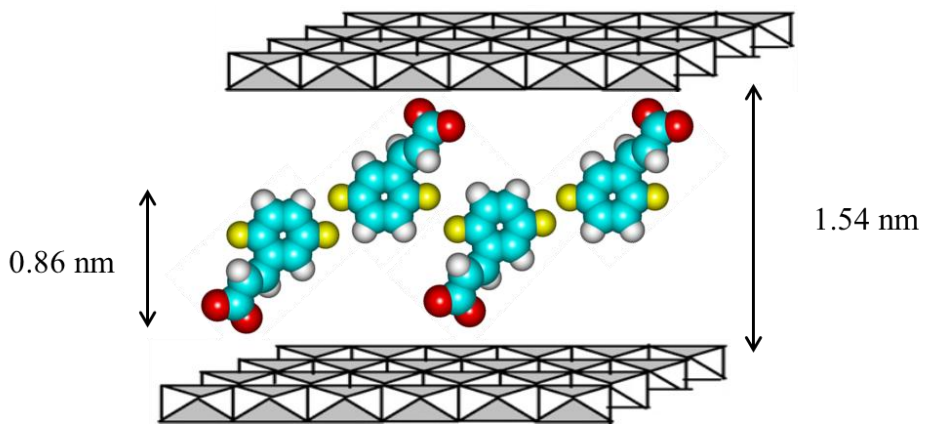

Fig. 54 A possible arrangement of acrylate ions in the interlayer space of the E-3(2',5'-difluorophenyl)propenoate $-\mathrm{Ca}_{3} \mathrm{Fe}-\mathrm{LDH}$ hybrid.

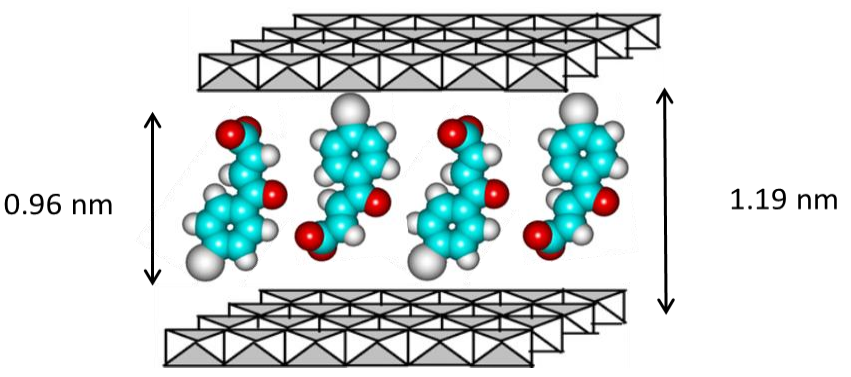

Fig. 55 A possible arrangement of acrylate ions in the interlayer space of the E-3(4'-chlorobenzoyl)propenoate $-\mathrm{Ca}_{3} \mathrm{Fe}-\mathrm{LDH}$.

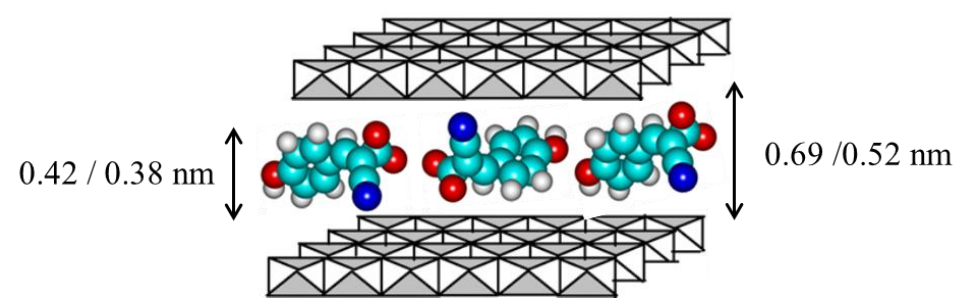

Fig. 56 A possible arrangement of acrylate ions in the interlayer space of the E-2-cyano-3(4'-hydroxyphenyl)propenoate- $\mathrm{Ca}_{3} \mathrm{Fe}-\mathrm{LDH}$ hybrid. 
spacing values, one may state that the intercalation of $E-2,3-$ dimethylpropenoate- $\mathrm{Ca}_{3} \mathrm{Fe}$ LDH and E-3(4'-imidazolyl)propenoate- $\mathrm{Ca}_{3} \mathrm{Fe}-\mathrm{LDH}$ was unsuccessful. However, SEM-EDX and FT-IR measurements gave convincing evidence that the formation of the organic-inorganic intercalated nanocomposite did take place. The dimensions of the anion for the $E-2,3$ dimethylpropenoate only allows monolayer formation in the gallery space of $\mathrm{Ca}_{3} \mathrm{Fe}$ LDH (Fig. 57), while two layers of E-3(4'-imidazoyl)propenoate may only fit in, if the total absence of the layerassociated water molecules is assumed. Since it is highly improbable, a monolayer arrangement may be suggested here as well (Fig. 58). 


\section{3. [2+2] topotactic cyclic photodimerization of propenoate derivatives using}

CaFe-LDH as nanoreactor

Photoreactions of propenoate derivatives are well known from the literature. We have shown previously in Ch. 2.5.1. that the dimerization of, e.g. E-phenylpropenoic acid can result in two main kinds of dimers on irradiation in the solid state (Fig. 59). The $\alpha$ types are head to tail (HT) dimers, where the two phenyl groups can be both syn and anti positions to each other, while the $\beta$-types are head to head $(\mathrm{HH})$ dimers [106], where the phenyl groups can also be syn or anti positions to each other. However, there is an important criterion for the dimerization to occur: the distance between the double bonds in the two interacting molecules must be in the range of $0.35-0.42 \mathrm{~nm}$ [106]. Let me note that beside photodimerization $E-Z$ isomerization is also possible [106].

Intercalated in $\mathrm{MgAl}-\mathrm{LDH}$, the photoreaction of the E-3-phenylpropenoate gave $\mathrm{HH}$-dimers with the predominance of the compound having the phenylic group in syn position and appreciable amount of the $Z$ isomer was also formed. The composition of the

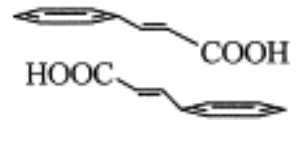

$\alpha$-Cinnamic Acid
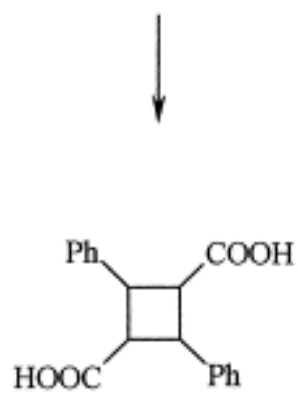

Head-to-Tail dimer

I

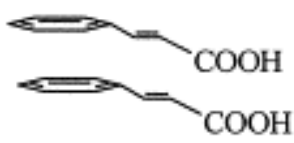

$\beta$-Cinnamic Acid
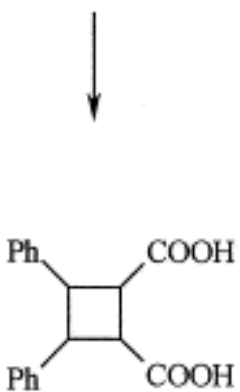

Head-to-Head dimer

II

Fig. 59 Possible dimerization products that may be obtained on irradiating crystalline E-3-phenylpropenoic acid: (I) HT-dimer (II) HH-dimer [131]

products depended on the distribution of the trivalent metals in the layers. [114]. Although the paper does not give any information about the arrangement of the $E$ 3-phenylpropenoate among the layers, it is clear that the photoreactions could be finetuned via the fixed arrangements of organic molecules in the confined space of LDHs.

Topotactic photodimerization of intercalated propenoate derivatives is expected to be influenced by the arrangement of the anions in the interlayer space. Of course, the above-mentioned distance criterion between the olefinic bonds must also be met. The occurrence or absence of photodimerization can be taken as an indication of the interlayer arrangement. Thus, the partly speculative sugges- 
tions given in the previous section may strengthened by these experimental observations. The marker of photodimerization is the decrease in intensity and, finally, the disappearance of the olefinic stretching vibration in the range of $1560-1670 \mathrm{~cm}^{-1}$.

The success of the photodimerization and the differences between the products starting from bulk (crystalline) and intercalated compounds are represented by the data shown in Table 7. As it can be seen, the photochemical reactions taking place in these systems can be classified into three groups. Either the type of the dimer is altered (i.e., HT in the bulk and $\mathrm{HH}$ in the intercalated material), or the LDH was found to be able to protect the organic molecules from photoreactions (it euphemistically states that there was no photoreaction), while there was reaction in the crystalline state, or there were no reactions in either state. 
Table 7 Comparison of the products of photochemical reactions with various propenoate derivatives (literature data and our own findings).

\begin{tabular}{|c|c|c|c|}
\hline Organic compound & source & $\begin{array}{c}\text { photochemical reaction } \\
\text { bulk compound }\end{array}$ & $\begin{array}{c}\text { photochemical reaction } \\
\text { intercalated anion }\end{array}$ \\
\hline$E$-3-phenylpropenoate & {$[106,108,129]$} & $\mathrm{HT}^{*}$ dimerization & $\mathrm{HH}^{* *}$ dimerization \\
\hline$E-3\left(4^{\prime}\right.$-nitrophenyl)propenoate & {$[106]$} & $\mathrm{HT}^{*}$ dimerization & $\mathrm{HH}^{* *}$ dimerization \\
\hline$E$-3(2'-thienyl)propenoate & {$[130]$} & $\mathrm{HT}^{*}$ dimerization & $\mathrm{HH}^{* *}$ dimerization \\
\hline$E$-2,3-dimethylpropenoate & present study & HT dimerization $* * *$ & no reaction \\
\hline$E-3\left(4^{\prime}\right.$-chlorobenzoyl)propenoate & present study & HT dimerization $* * *$ & no reaction \\
\hline$E-3\left(2^{\prime}, 5^{\prime}\right.$-difluorophenyl)propenoate & present study & HT dimerization $* * *$ & $\mathrm{HH}^{* *}$ dimerization \\
\hline $\begin{array}{c}E \text {-2-cyano-3(4'-hydroxyphenyl)- } \\
\text { propenoate }\end{array}$ & present study & no reaction & no reaction \\
\hline E-3(4'-imidazolyl)propenoate & present study & HT dimerization $* * *$ & no reaction \\
\hline
\end{tabular}

*HT - head to tail, **HH - head to head, ***most probably 
Let us list first those anions where there was no photodimerization, neither in the crystalline state nor in the intercalated material. The E-3(4'-chlorobenzoyl)propenoate, and the E-2-cyano-3(4'-hydroxyphenyl)propenoate anions displayed no photodimerization activity in any forms (Fig. 60). For the intercalated material the spectrum of the LDH is subtracted (and it is always done for all the intercalated materials to be discussed in the followings).

I.

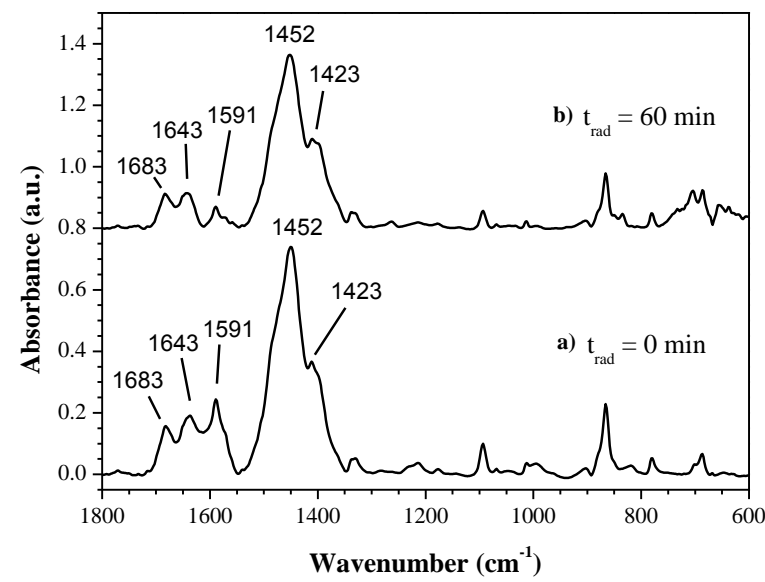

III.

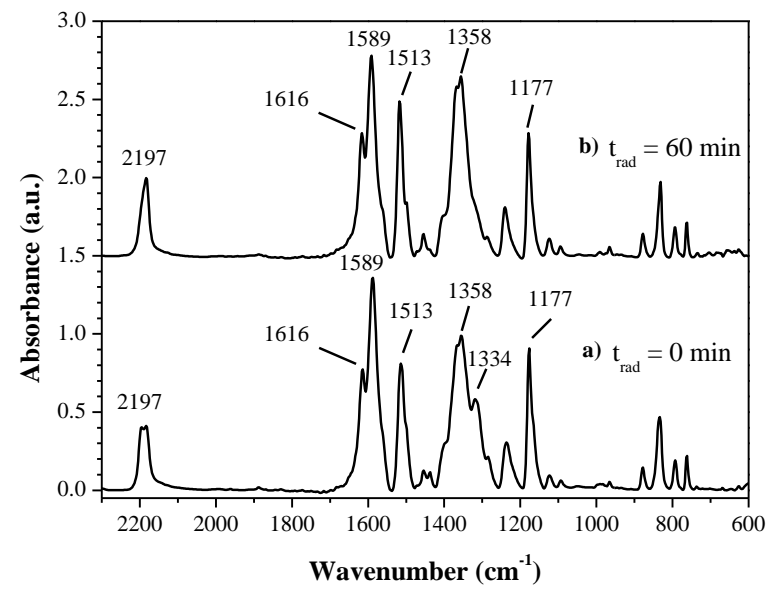

II.

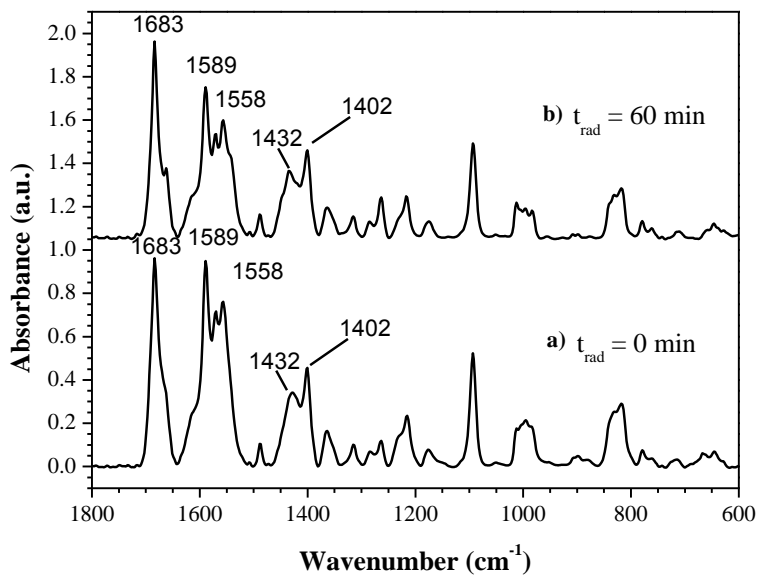

IV.

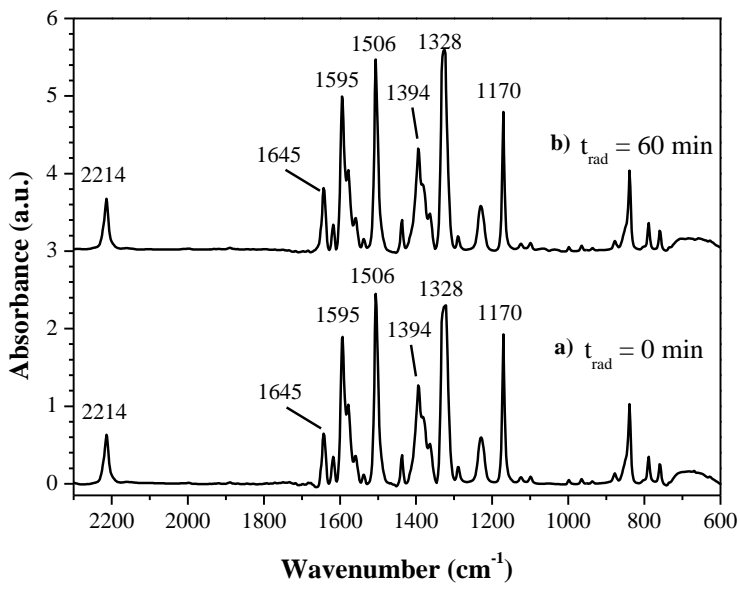

Fig. 60 Infrared spectra of the (I.) $E-3\left(4^{\prime}\right.$-chlorobenzoyl)propenoate in the crystalline state and (II.) its intercalated form; (III.) E-2-cyano-3(4'-hydroxyphenyl)propenoate in the crystalline state and (IV.) its intercalated form; (a) before photolysis; (b) after $60 \mathrm{~min}$ photolysis. 
I.

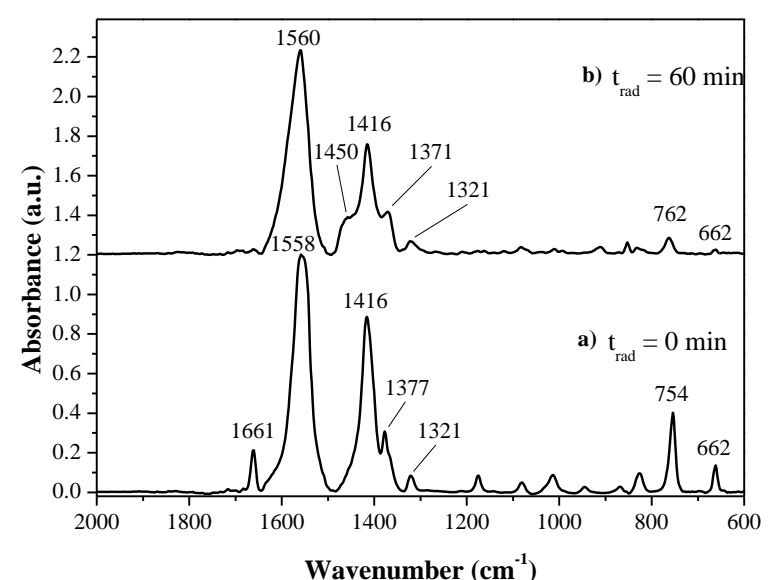

III.

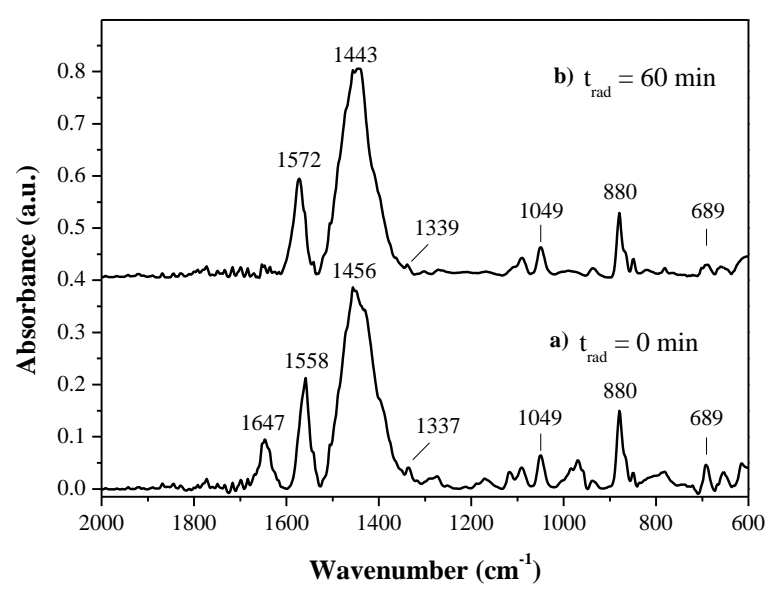

II.

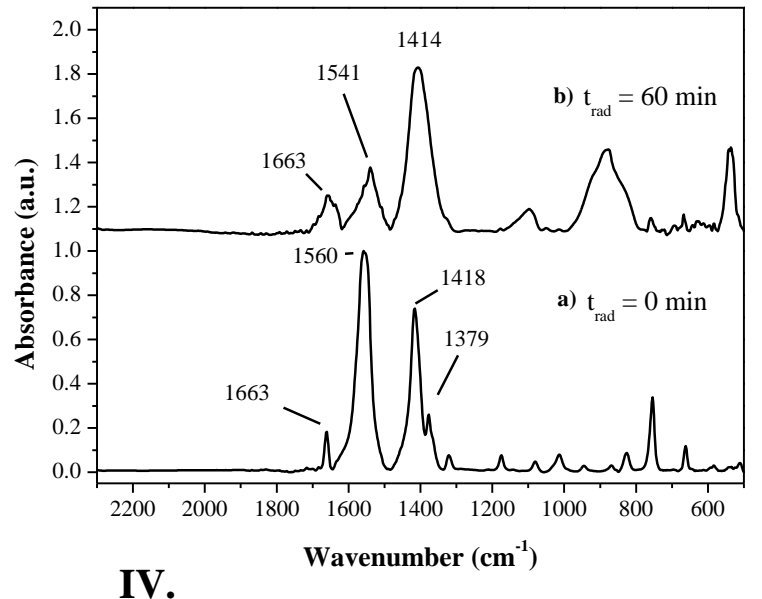

IV.

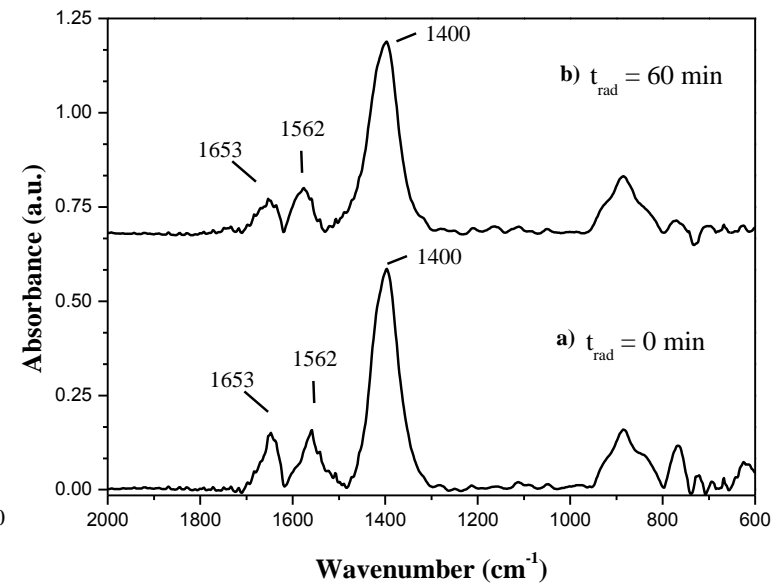

Fig. 61 Infrared spectra of the (I.) Na-E-2,3-dimethylpropenoate in the crystalline state and (II.) its intercalated form (III.) Na-E-3(4'-imidazoyl)propenoate in the crystalline state and (IV.) its intercalated form: a) before photolysis; b) after 60 min photolysis

E-2,3-dimethylpropenoate and E-3(4'-imidazolyl)propenoate photodimerized only in the bulk Na-salt form (Fig. 61). In the confined space no reaction was observed. For the last three intercalated anions the interlayer structural arrangements, suggested in the previous section (Figs. 56-58), predict that the distance criterion for the photodimerization to occur cannot be met, thus, the lack of this transformation is not surprising. For the $E$ 3(4'-chlorobenzoyl)propenoate anion the bulkiness of the substituent on the phenyl group does not allow a close enough proximity of the double bonds for two neighboring anions in the crystalline state (photodimerization did not take place). The suggested structural arrangement (Fig. 55) for the intercalated anion, in principal, can be adequate for the reaction to take place, however, the distance between the double bonds will not be smaller 
than in the crystalline state, since the bulkiness of the anion remains, plus the trivalent cations may not be in the optimum distance either.

Out of the eight anions studied four have shown photochemical reaction in the confined space as well. They are $E$-3-phenylpropenoate, $E$-3(4'-nitrophenyl)propenoate, $E$ 3(2'-thienyl)propenoate and E-3(2',5'-difluorophenyl)propenoate. Their IR spectra clearly demonstrate that photodimerization did take place both in the crystalline state and in the confined space of the LDH. Moreover, if one inspects the spectra of the products pairwise, will see that they indicate differences in the mechanisms of formation in the crystalline state and the interlayer space of the LDH. More detailed analyses of the IR spectra are presented below.

\subsubsection{Topotactic reaction of E-3-phenylpropenoate and its intercalated form}

The IR spectra of the bulk compounds as well as the intercalated anions were recorded before and after photolysis (Fig. 62). The 2000-600 $\mathrm{cm}^{-1}$ region of the IR spectra are shown for the bulk Na-salt (I.) and the intercalated E-3-phenylpropenoate (II.) before (a) and after 60 min of photolysis (b).

After $60 \mathrm{~min}$ the band at $1640 \mathrm{~cm}^{-1}$, assigned to $v(\mathrm{C}=\mathrm{C})$, disappeared, i.e., photodimerization did take place. The peak at $1702 \mathrm{~cm}^{-1}$ is an indication of the presence of some $Z$ isomer. The corresponding carboxylate vibrations could be located (see Table 6).

I.

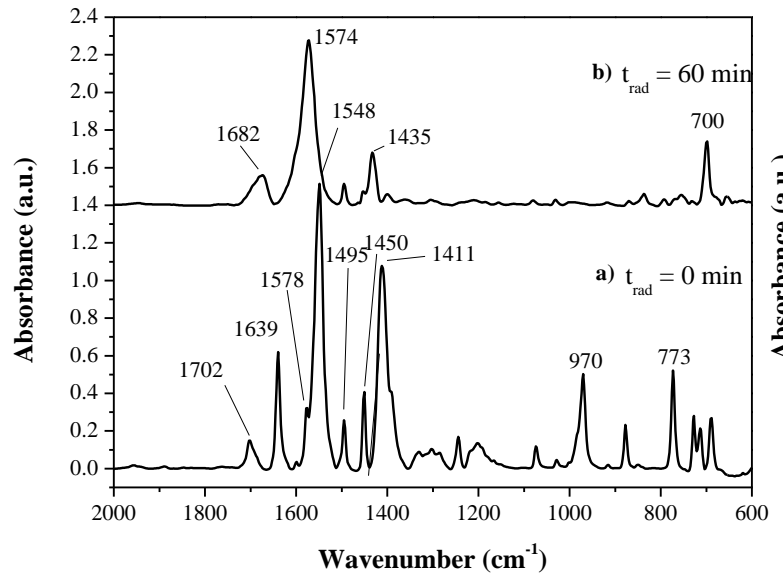

II.

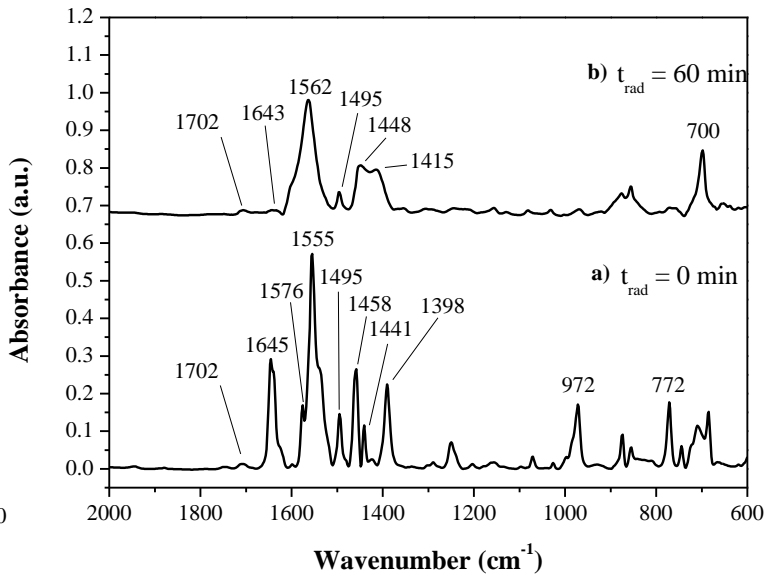

Fig. 62 Infrared spectra of the (I.) E-3-phenylpropenoate in the crystalline state and (II.) its intercalated form, a) before photolysis; b) after $60 \mathrm{~min}$ photolysis. 
Photodimerization went to completion both in the crystalline (bulk) form and the interlayer space of the LDH. In order to make peak identification easier, the wavenumber data of the most relevant bands to this study for the monomer and the photodimer are collected in Table 8 following the assignation pattern suggested by Allen et al [108].

Table 8 The most significant bands observed in the infrared spectrum E-3-phenylpropenoic acid and $E$-3-phenylpropenoate monomers and dimers.

\begin{tabular}{ccccccc}
\hline Vibrations & $\begin{array}{c}\text { monomer } \\
\text { literature }\end{array}$ & $\begin{array}{c}\text { monomer } \\
\text { Na-salt, } \\
\text { experimental }\end{array}$ & $\begin{array}{c}\text { monomer } \\
\text { (intercalated } \\
\text { form) }\end{array}$ & $\begin{array}{c}\text { dimer } \\
\text { literature }\end{array}$ & $\begin{array}{c}\text { dimer } \\
\text { Na-salt, } \\
\text { experimental }\end{array}$ & $\begin{array}{c}\text { dimer } \\
\text { (intercala- } \\
\text { ted form) }\end{array}$ \\
\hline$v(\mathrm{C}=\mathrm{O})$ & 1680 & $1578(Z)$ & $1576(Z)$ & - & 1574 & 1562 \\
$($ carboxylate $)$ & & $1548(E)$ & $1555(E)$ & & & \\
$v(\mathrm{C}=\mathrm{C})$ & 1627 & $1702(Z)$ & $1702(Z)$ & - & - & - \\
$($ aliphatic $)$ & & $1639(E)$ & $1645(E)$ & & & \\
$v(\mathrm{C}-\mathrm{O})$ & 1318,1289, & $1435(Z)$, & $1495(Z)$, & 1332 & 1435 & 1448 \\
$($ carboxylate $)$ & 1266 & $11450(E)$ & $1458(E)$ & & & \\
\hline
\end{tabular}

If the results corresponding to the intercalated anion are unified with the suggested spatial arrangement (Fig. 51), it is reasonable to state that HH-dimer, the Na-salt of $\alpha$ truxinic acid was formed.

The IR spectra of the photodimers in the bulk and the intercalated state differ, mostly HT-dimer were formed in the crystalline state.

\subsubsection{Topotactic reaction of E-3(4'-nitrophenyl)propenoate and its intercalated form}

The photodimerization ability of $E-3\left(4^{\prime}\right.$-nitrophenyl)propenoate in the crystalline state is also known from the literature [106].

The IR spectra of the bulk Na-salt and the intercalated form of E-3(4'-nitrophenyl)propenoate before and after irradiation are displayed in Fig. 63. For easier peak identification relevant wavenumber data are collected in Table 9. 
I.

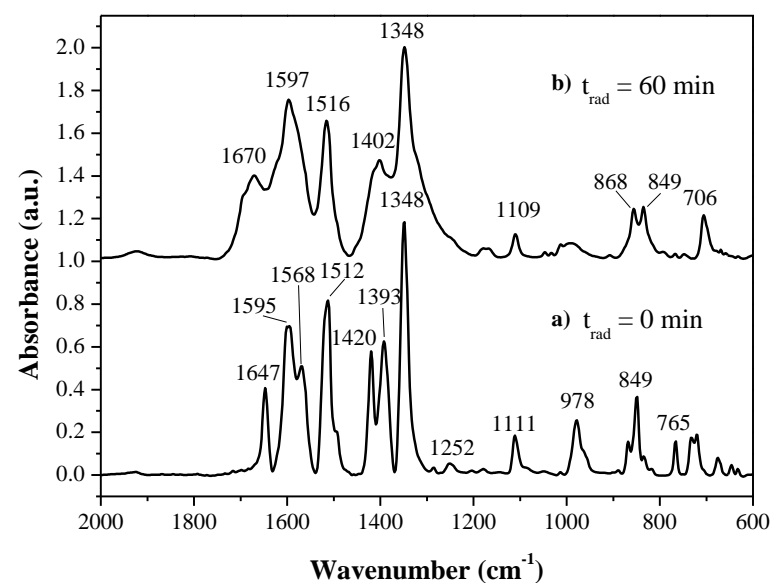

II.

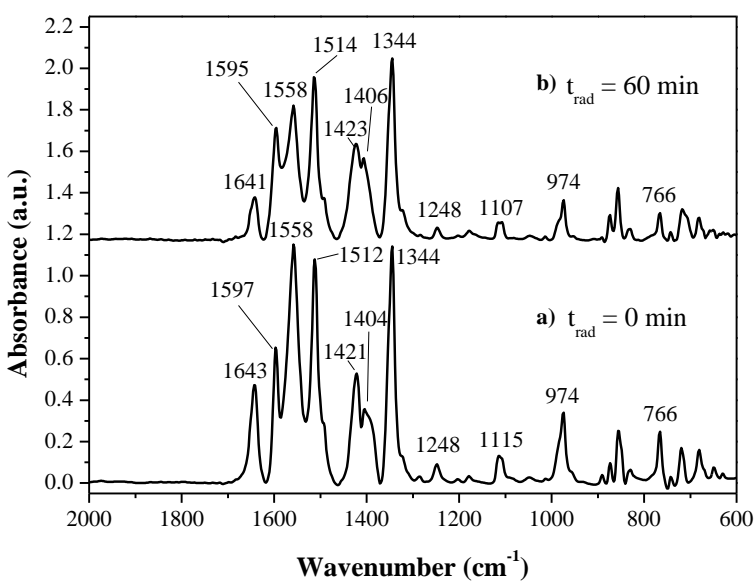

Fig. 63 Infrared spectra of the (I.) E-3(4'-nitrophenyl)propenoate and (II.) its intercalated form, a) before photolysis; b) after 60 min photolysis

Table 9 The most significant bands observed in the infrared spectrum E-3(4'-nitrophenyl)propenoate monomer and dimer.

\begin{tabular}{ccccc}
\hline $\begin{array}{c}\text { Approximate } \\
\text { description }\end{array}$ & $\begin{array}{c}\text { monomer } \\
\text { Na-salt, } \\
\text { experimental }\end{array}$ & $\begin{array}{c}\text { monomer } \\
\text { intercalated } \\
\text { form }\end{array}$ & $\begin{array}{c}\text { dimer } \\
\text { Na-salt, } \\
\text { experimental }\end{array}$ & $\begin{array}{c}\text { dimer } \\
\text { intercalated } \\
\text { form }\end{array}$ \\
\hline $\begin{array}{c}v(\mathrm{C}=\mathrm{O}) \\
(\text { carboxylate })\end{array}$ & 1595 & 1597 & 1597 & 1595 \\
$v(\mathrm{C}=\mathrm{C})($ aliphatic $)$ & 1647 & 1643 & 1670 & 1641 \\
$v\left(\mathrm{NO}_{2}\right)$ & 1512 & 1512 & 1516 & 1512 \\
$v(\mathrm{C}-\mathrm{O})$ & 1420 & 1421 & 1402 & 1423 \\
$v\left(\mathrm{NO}_{2}\right)$ & 1348 & 1344 & 1348 & 1344 \\
\hline
\end{tabular}

Upon irradiating the crystalline compounds for 60 minutes, no significant changes are seen in the spectra except that the resolution decreased. One tends to state that only slight if any photodimerization occurred. This clearly in contrast with literature data, however, they were dealing with single crystalline material while our sample was polycrystalline.

However, on irradiating the intercalated material a decrease in the intensity of the band attributed to the carbon-carbon double bond is seen. The reaction by far did not go to completion, but partial photodimerization did take place. After inspecting the suggested 
structural arrangement in Fig. 52, the formation of the HH-dimer may be proposed, i.e., the $\mathrm{Na}$-salt of the $\alpha$-dinitrotruxinic acid may be formed.

\subsubsection{Topotactic reaction of E-3(2'-thienyl)propenoate and its intercalated form}

Here as well, the IR spectrum of the intercalated E-3(2'-thienyl)propenoate did not differ significantly from that in the crystalline form indicating that no chemical transformation took place during intercalation.

On irradiation both the crystalline and the intercalated $E-3\left(2^{\prime}-\right.$ thienyl)propenoate photodimerized indicating by the nearly complete disappearance of the band corresponding to the stretching vibration of the olefinic bond at $1634 \mathrm{~cm}^{-1}$ (Fig. 64).

The most significant IR peak positions relevant to this study are collected in Table $\mathbf{1 0}$.

Using the proposed arrangement of the anion in-between the layers (Fig. 53), HH dimerization reaction may be suggested once again.
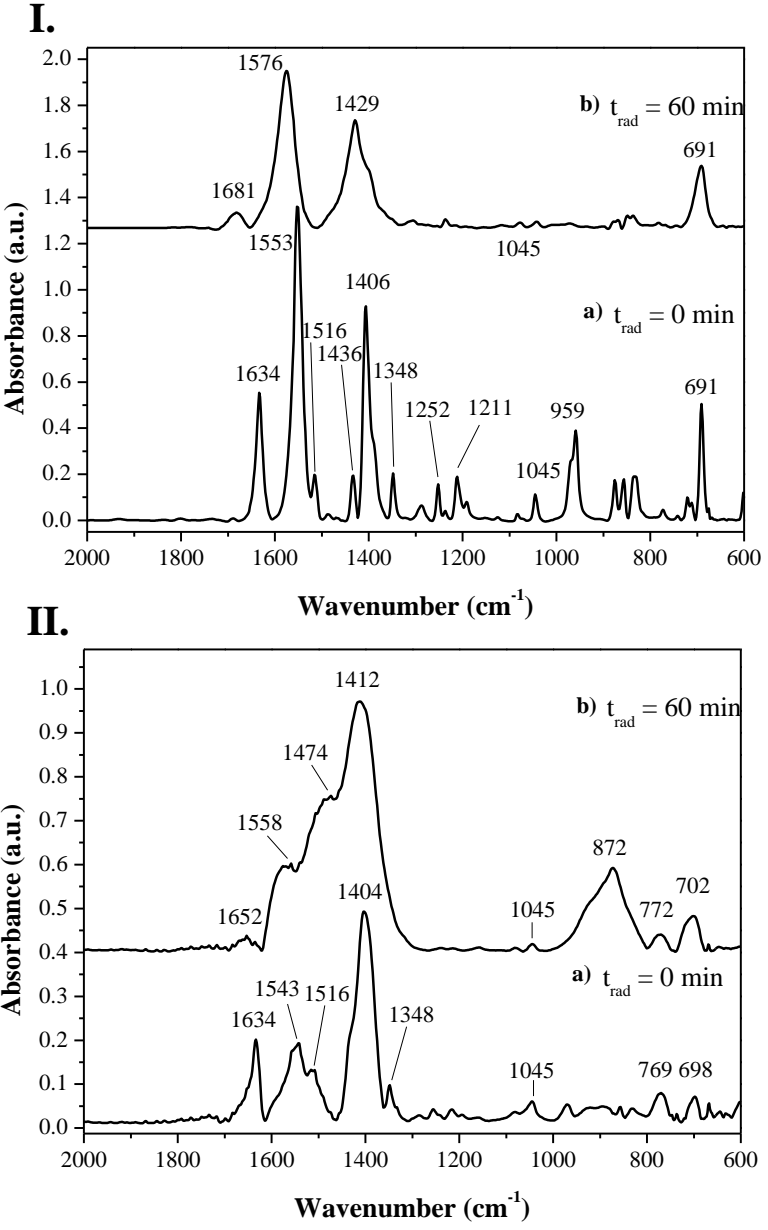

Fig. 64 Infrared spectra of the (I.) $E-3\left(2^{\prime}-\right.$ thienyl)propenoate and (II.) its intercalated form, (a) before photolysis; (b) after $60 \mathrm{~min}$. photolysis

Since this spectrum is significantly different from that of the irradiated crystalline Na-salt, it is safe to say that the resulting photodimer must also be different. Probably, HT-dimer(s) were formed at least in majority. 
Table 10 The most significant bands observed in the infrared spectrum $E-3\left(2^{\prime}\right.$-thienyl)propenoate monomer and dimer.

\begin{tabular}{ccccc}
\hline Vibrations & $\begin{array}{c}\text { monomer } \\
\text { Na-salt, } \\
\text { experimental }\end{array}$ & $\begin{array}{c}\text { monomer } \\
\text { intercalated form }\end{array}$ & $\begin{array}{c}\text { dimer } \\
\text { Na-salt, } \\
\text { experimental }\end{array}$ & $\begin{array}{c}\text { dimer } \\
\text { intercalated form }\end{array}$ \\
\hline $\begin{array}{c}v(\mathrm{C}=\mathrm{O}) \\
(\text { carboxylate }) \\
v\end{array}$ & 1553 & 1543 & 1576 & 1558 \\
$\begin{array}{c}\mathrm{C}=\mathrm{C})(\text { aliphatic }) \\
v\end{array}$ & 1634 & 1634 & 1681 & 1652 \\
$\begin{array}{c}\mathrm{C}=\mathrm{C})(\text { aromatic }) \\
v(\mathrm{C}-\mathrm{O})\end{array}$ & 1487,1434, & 1404,1348 & 1429 & - \\
& 1406,1348 & 698 & - & 702 \\
$v(=\mathrm{C}-\mathrm{S}-\mathrm{C}=)$ & 691 & 6916 & \\
\hline
\end{tabular}

\subsubsection{Topotactic reaction of E-3(2',5'-difluorophenyl)propenoate and its intercalated form}

Upon irradiating the crystalline $E-3\left(2^{\prime}, 5^{\prime}\right.$-difluorophenyl)propenoate salt, after 60 minutes significant changes are seen in the IR spectrum (Fig. 65/I.). The olefinic bands at $1645 \mathrm{~cm}^{-1}$ seems to disappear, i.e., photodimerization occurred.

Irradiation of the intercalated $E-3\left(2^{\prime}, 5^{\prime}\right.$-difluorophenyl)propenoate anion resulted in the complete disappearance of the band at $1648 \mathrm{~cm}^{-1}$, attributed to the stretching vibration of the olefinic double bond. This is the clear sign of the successful dimerization.

The assignations of the most significant bands related to this study are summarized in Table 11.

A comparison of the IR spectrum of the bulk reactants and the intercalated one after 60-min irradiation significant differences are seen, thus the photodimers must also be different. Taking into account the possible interlayer arrangement of $E-3\left(2^{\prime}, 5^{\prime}\right.$-difluorophenyl)propenoate ions (Fig. 54), HH-dimer is proposed to be formed in the confined state, while, most probably, HT-dimer is formed in the crystalline state. 
I.

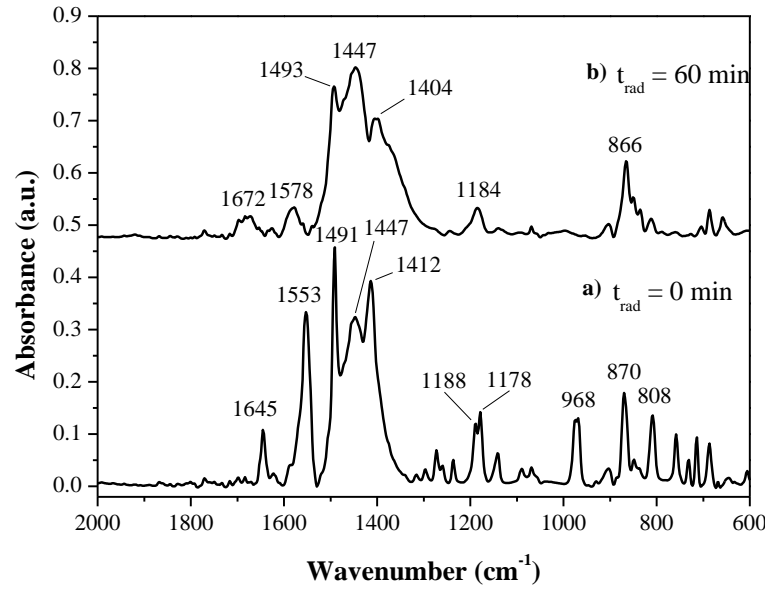

II.

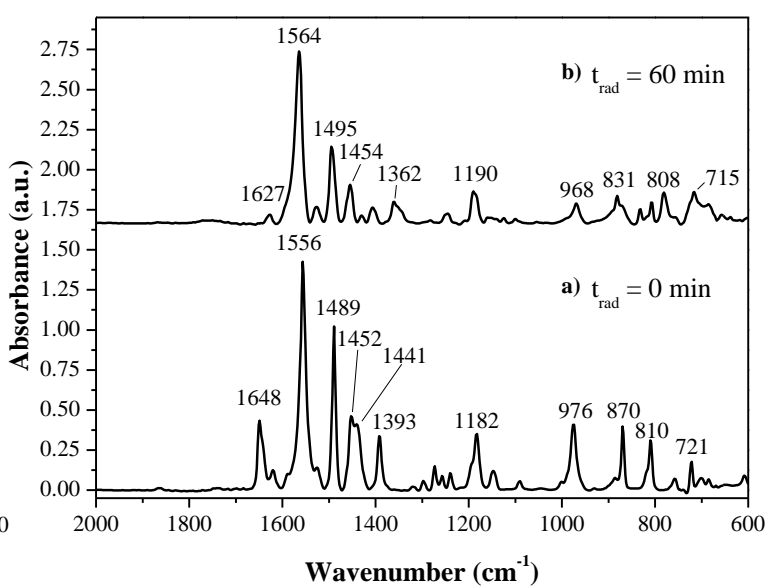

Fig. 65 Infrared spectra of the (I.) $E-3\left(2^{\prime}, 5^{\prime}\right.$-difluorophenyl)propenoate and (II.) its intercalated form, (a) before photolysis; (b) after 60 min photolysis.

Table 11 The most significant bands observed in the infrared spectrum $E-3\left(2^{\prime}, 5^{\prime}\right.$-difluorophenyl)propenoate monomer and dimer.

\begin{tabular}{ccccc}
\hline Vibrations & $\begin{array}{c}\text { monomer } \\
\text { Na-salt, } \\
\text { experimental }\end{array}$ & $\begin{array}{c}\text { monomer } \\
\text { intercalated form }\end{array}$ & $\begin{array}{c}\text { dimer } \\
\text { Na-salt, } \\
\text { experimental }\end{array}$ & $\begin{array}{c}\text { dimer } \\
\text { intercalated form }\end{array}$ \\
\hline $\begin{array}{c}v(\mathrm{C}=\mathrm{O}) \\
(\text { carboxylate })\end{array}$ & 1553 & 1556 & 1578 & 1564 \\
$v(\mathrm{C}=\mathrm{C})($ aliphatic $)$ & 1645 & 1648 & - & - \\
$v(\mathrm{C}-\mathrm{O})$ & 1447 & 1489 & 1447 & 1495 \\
$($ carboxylate $)$ & 1188,1178 & 1182 & 1184 & 1190 \\
$v(\mathrm{C}-\mathrm{F})$ & & & & \\
\hline
\end{tabular}




\section{SUMMARY}

Layered double hydroxides (LDHs) are brucite-like materials in which the divalent metal ions are partially substituted for trivalent ones. Thus, the layers contain octahedrally coordinated di- and trivalent metal ions, and the layers are positively charged. This charge is usually compensated by fully or partially hydrated inorganic ions. LDHs are versatile substances having many uses; they can serve as catalyst supports, catalysts, flame retardants, containers of biologically active compounds, to mention just a few. Although some are found in nature, for applications they are usually synthesized. The most frequently used representative is synthetic hydrotalcite, in which $\mathrm{Mg}(\mathrm{II})$ and $\mathrm{Al}(\mathrm{III})$ are the metal ions. It is generally believed that LDHs are formed when the ionic radii of the diand trivalent metal ions are close to each other. Respecting this dogma many LDHs were made, nevertheless, they were studied significantly less thoroughly than the $\mathrm{Mg}$ (II)Al(III)$\mathrm{LDH}$.

These materials have anion exchange ability, thus various hybrid materials may be prepared with useful functionalities. Originally, the aim was to exchange the simple inorganic anions for robust isopoly or heteropoly acid anions to obtain durable catalysts with acid-base (most of the original LDHs are basic materials) and redox properties of channel structure with molecular size openings, thus combining different chemical functionalities and shape selectivity. However, it turned out that the direct ion exchange was not an easy exercise. The feasible way proved to be exchanging the original anions to bulky organic anions, then, finishing the exchange with the large inorganic ions. More recently, it became clear that the intermediate step, i.e., exchanging the small inorganic ions to bulky organic anions, may produce even more interesting and useful functional materials than the whole procedure.

At the start of the project leading to this dissertation, we were able to prepare a material containing $\mathrm{Ba}(\mathrm{II})$ and $\mathrm{Fe}(\mathrm{III})$ ions under hyperalkaline conditions (in the presence of $\mathrm{NaOH}$ over $10 \mathrm{M}$ concentration), which was proved to be of layered structure in spite of the significant difference in the ionic radii of the two ions $[0.149 \mathrm{~nm}$ for $\mathrm{Ba}(\mathrm{II})$ and 0.069-0.079 $\mathrm{nm}$ for Fe(III)]. The accumulated knowledge briefly outlined above and this enlightening result initiated us to

- explore the experimental conditions and finding the limits under which $\mathrm{Ba}(\mathrm{II}) \mathrm{Fe}(\mathrm{III}) \mathrm{LDHs}$ are formed, 
- characterize this novel material with as many tools as it is possible,

- extend the synthetic efforts for the other members of the alkaline earth ions keeping $\mathrm{Fe}(\mathrm{III})$ as the trivalent counterpart and to characterize them in as many ways as it is possible,

- find the most efficient method for the synthesis of inorganic-organic hybrid materials where the host material is $\mathrm{Ca}(\mathrm{II}) \mathrm{Fe}(\mathrm{III})-\mathrm{LDH}$ and the guest anions are various acrylates,

- characterize the organic-inorganic hybrids with all available methods,

- explore the possibility of using the organic-inorganic hybrids as nanoreactors in $[2+2]$ topotactic cyclisation reactions.

At the beginning of this work I was able to synthesize a novel layered double hydroxide, $\mathrm{Ba}(\mathrm{II}) \mathrm{Fe}(\mathrm{III}) \mathrm{LDH}$ that is, invalidating the dogma that the di- and trivalent ions in LDHs must have similar ionic radii. During further experimental work the finding has been verified by various methods (powder XRD, ${ }^{57} \mathrm{Fe}$ Mössbauer spectroscopy, SEM-EDX elemental maps, TG-DTG) that the co-precipitation of the aqueous solutions of $\mathrm{Ba}(\mathrm{II})$ and $\mathrm{Fe}(\mathrm{III})$ salts only leads the layered double hydroxides under hyperalkaline conditions $\left(\mathrm{c}_{\mathrm{NaOH}} \geq 10 \mathrm{M}\right)$ in the $2-4: 1 \mathrm{Ba}(\mathrm{II}): \mathrm{Fe}(\mathrm{III})$ range. The coordination environment of the $\mathrm{Fe}(\mathrm{III})$ was found to be octahedral in the $\mathrm{LDH}$, the $\mathrm{Fe}-\mathrm{O}$ distance was $200 \mathrm{pm}$ and $\sim 400 \mathrm{pm}$ in the first and third coordination spheres, respectively. In the second coordination sphere $\mathrm{Fe}(\mathrm{III})$ and $\mathrm{Ba}(\mathrm{II})$ ions were found by XAS spectroscopy at $\sim 300 \mathrm{pm}$. Upon heating above $453 \mathrm{~K}$ the $\mathrm{LDH}$ structure deteriorated and from now on the environment gradually turned tetrahedral. On XAS spectra changes were seen in the second and third coordination sphere first, then, at $523 \mathrm{~K}$ the first coordination sphere also altered significantly indicating the collapse of the layered structure.

Optimal conditions were found for the formation of layered double hydroxides when $\mathrm{Mg}(\mathrm{II}), \mathrm{Ca}(\mathrm{II})$ were the alkaline earth ions under "normal" alkaline conditions. Many conditions were tried and it was found, verified by XRD, TG-DTG, SEM, SEM-EDX elemental maps, that using a wide range of $\mathrm{Mg}(\mathrm{II})[\mathrm{Ca}(\mathrm{II})]: \mathrm{Fe}(\mathrm{III})$ ratios the method of keeping the final $p \mathrm{H}$ at 13 in the co-precipitation reaction and maintaining $\mathrm{CO}_{2}$-free environment provides with the optimum conditions for LDH synthesis.

Interestingly, $\mathrm{Sr}(\mathrm{II}) \mathrm{Fe}(\mathrm{III}) \mathrm{LDHs}$ could not be prepared irrespective of the alkalinity of the precipitating medium. 
For the preparation of intercalated organic-inorganic nanohybrids the $\mathrm{Ca}_{3} \mathrm{Fe}-\mathrm{LDH}$ was chosen as host. Probing various methods (direct ion exchange, co-precipitating the organic and the inorganic components, dehydrating the LDH host and rehydrating it in the presence of the organic anion), the last one, the dehydration-rehydration method was found to be the best for the preparation of acrylate [E-phenylpropenoate, $E$-3(4'-nitrophenyl) propenoate, $E-3\left(2^{\prime}, 5^{\prime}\right.$-difluorphenyl)propenoate, $E$-3(4'-chlorbenzoyl)propenoate, $E$-2cyano-3-phenylpropenoate, $E$-3(4'-imidazolyl)propenoate or $E$-3(2'-thienyl)propenoate]-Ca(II)Fe(III) LDH nanocomposites verified by XRD, TG-DTG measurements, SEM-EDX elemental maps and FT-IR spectroscopy. The possible arrangements for the organic anions were suggested on the basis of basal spacing from XRD measurements, the estimate of layer thickness and the dimensions of the quantum chemically optimized structures of the acrylate ions.

Using the acrylate- $\mathrm{Ca}(\mathrm{II}) \mathrm{Fe}(\mathrm{III})-\mathrm{LDHs}$ as nanoreactors, photoinitiated topotactic $[2+2]$ cyclisation reactions could be performed with many representatives [E-phenylpropenoate-, E-3(4'-nitrophenyl)propenoate-, $E-3\left(2^{\prime}, 5^{\prime}\right.$-difluorphenyl)propenoate- or $E$ 3(2'-thienyl)propenoate- $\mathrm{Ca}(\mathrm{II}) \mathrm{Fe}(\mathrm{III})-\mathrm{LDHs}$ ] resulting in cyclobutane derivatives within the layers of the host material. The progress of the cyclisation reactions could be followed by monitoring the disappearance of $\mathrm{C}=\mathrm{C}$ vibration at $\sim 1600 \mathrm{~cm}^{-1}$. The mere fact of that cyclisation took place indicated that there were domains where the intercalated anions were in close vicinity to each other and in proper arrangement.

Instrumental measurements attested that the $E-3\left(4^{\prime}\right.$-chlorbenzoyl)propenoate, the $E$ 2-cyano-3-phenylpropenoate, the E-2,3-dimethylpropenoate and the $E$-3(4'-imidazolyl)propenoate anions were intercalated in $\mathrm{Ca}(\mathrm{II}) \mathrm{Fe}(\mathrm{III}) \mathrm{LDH}$, however, their arrangements and/or their distances were not suitable for the topotactic reaction to proceed. 


\section{7. ÖSSZEFOGLALÁS}

A réteges kettős hidroxidok ( $\mathrm{LDH}-\mathrm{k})$ a brucithoz $\left[\mathrm{Mg}(\mathrm{OH})_{2}\right]$ hasonló szerkezettel jellemezhetőek, csak itt a kétértékü fémionok egy részét háromértékü fémionok helyettesítik. Ezért a rétegeknek, amelyekben a két- és háromértékü fémionok oktaéderes koordinációban vannak, pozitív töltésük van. Ezt a pozitív töltést általában, részben vagy teljesen hidratált szervetlen anionok kompenzálják. Az LDH-k szerkezete jól alakítható, ezért sokféle területen felhasználhatók: lehetnek katalizátorhordozók, katalizátorok, égést visszatartó/lassító anyagok, biológiailag aktív vegyületek hordozói, hogy csak néhány példát említsek. Bár egy a természetben is elforduló ásványcsoportról van szó, gyakorlati alkalmazásukhoz szintetikus úton állítják elő őket. A legismeretbb és a leggyakrabban használt képviselőjük a szintetikus hidrotalcit, amelynek rétegeit $\mathrm{Mg}$ (II) és $\mathrm{Al}$ (III) fémionok alkotják. Általánosan elfogadott szabály, hogy az LDH-k sikeres szintéziséhez a két és háromértékü fémionokat úgy kell megválasztani, hogy azok ionrádiuszai jelentősen ne térjenek el egymástól. Ezt figyelembe véve igen változatos összetételü LDH-kat állítottak már elő, ám egyiküket sem tanulmányozták annyira alaposan, mint a $\mathrm{Mg}(\mathrm{II}) \mathrm{Al}(\mathrm{III})-\mathrm{LDH}-\mathrm{t}$, a hidrotalcitot.

Az ilyen típusú anyagok anioncserélő tulajdonságából következően sokféle, különböző funkciójú hibrid anyag előállítása lehetséges. Eredetileg az egyszerű szervetlen anionokat nagyobb izopoli- vagy heteropolisavak anionjaira cserélték, amivel olyan a szigorú reakciókörülményeket is jól türő katalizátorokat akartak előállítottani, amelyekben a sav-bázis tulajdonságokat (a legtöbb kezeletlen LDH bázikus tulajdonságú) kombinálódnak a polisavak redoxi sajátságaival, és kihasználhatók a gazda LDH réteges sajátságaiból származó alakszelektivitás is. Ahogy az a későbbiekben kiderült, a közvetlen ioncsere nem is olyan egyszerü feladat, mint ahogy azt korábban feltételezték. Sokkal könnyebben kivitelezhető az anioncsere úgy, ha több lépésben valósítják meg. Az eredeti anionokat először nagyméretü szerves anionokkal cserélik ki, amelyekkel a rétegeket kitámasztják, így a rétegek közötti térbe a nagy szervetlen anionok már könnyebben be tudnak épülni. Nem is annyira régen viszont arra is fény derült, hogy az első lépéssel kisebb szervetlen anionok szerves anionra cserélésével - sokkal érdekesebb, funkciójukban is hasznosabb új anyagokhoz lehet jutni.

A disszertációhoz vezető kísérleti munka kezdetén, extrém lúgos körülmények között (a NaOH koncentrációja nagyobb volt 10 M-nál) sikerült elöállítanunk 
$\mathrm{Ba}(\mathrm{II}) / \mathrm{Fe}(\mathrm{III})$-tartalmú kettős hidroxidot. A kísérleti munka során, annak ellenére, hogy a két fémnek az ionrádiuszai jelentősen eltérnek egymástól [0.149nm a Ba(II) és 0.069$0.079 \mathrm{~nm}$ a Fe(III) esetében] bebizonyosodott, hogy a kettős hidroxid réteges szerkezetü. Ez a megfigyelés jelentősen eltért attól, amit a terület kutatói az LDH-k képződéséről eddig hittek. Úgy láttuk, hogy ezen az úton érdemes továbbmennünk és vizsgálatainkat a következő irányokba kiterjesztenünk:

- a kísérleti körülmények szisztematikus változtatásával a Ba(II)Fe(III)-LDH keletkezéséhez szükséges feltételek leírása,

- az új anyag szerkezeti jellemzése a lehető legtöbb szerkezetvizsgáló módszer alkalmazásával,

- a szintézismódszer kiterjesztése az alkáliföldfém sor többi tagjára is úgy, hogy a háromértékü fém minden esetben a Fe(III) maradjon,

- a kapott anyagok jellemzése az összes általunk elérhető módszerrel,

- a lehető legmegfelelőbb szintézismódszer kikísérletezése olyan szervetlenszerves hibrid anyagok előállítására, amelynél a gazda anyag a $\mathrm{Ca}(\mathrm{II}) \mathrm{Fe}(\mathrm{III})-\mathrm{LDH}$ és a vendég anionok pedig akrilátszármazékok,

- a kapott szerves-szervetlen hibridanyagok jellemzése az összes általunk elérhető módszerrel,

- a szerves-szervetlen hibridanyagok felhasználása nanoreaktorként, [2+2] fotoiniciált topotaktikus ciklizációs reakciókhoz.

A doktori munkám során sikeresen állítottam elő egy olyan új réteges kettős hidroxidot, $\mathrm{Ba}(\mathrm{II}) \mathrm{Fe}(\mathrm{III})-\mathrm{LDH}-\mathrm{t}$, amely megcáfolja azt a dogmát, miszerint a sikeres LDHszintézis alapkövetelménye a rétegeket alkotó két- és háromértékü fémionok ionrádiuszának közel hasonlónak kell lennie. Sokféle szerkezetvizsgáló módszerrel (XRD, ${ }^{57} \mathrm{Fe}$ Mössbauer spektroszkópia, SEM-EDX elemtérképek, TG-DTG) bebizonyítottuk, hogy $\mathrm{Ba}(\mathrm{II})$ és $\mathrm{Fe}(\mathrm{III})$ sók vizes oldatának együttes lecsapásával réteges kettős hidroxidot lehet elöállítani extrém lúgos közegben $\left(\mathrm{c}_{\mathrm{NaOH}} \geq 10 \mathrm{M}\right)$, ha a $\mathrm{Ba}(\mathrm{II}): \mathrm{Fe}(\mathrm{III})$ arány 2:1-4:1 intervallumban található. Az LDH-ban a vas oktaéderes koordinációjú, a Fe-O távolság $\sim 200$ pm és $400 \sim$ pm az első és harmadik koordinációs szférában. A második koordinációs szférában a $\mathrm{Fe}(\mathrm{III})$ és a $\mathrm{Ba}$ (II) ionok közötti távolság 300 pm volt röntgenabszorpciós (XAS) spektroszkópiai vizsgálatok alapján. Hökezelés hatására $453 \mathrm{~K}$ felett az LDH szerkezete torzul és tetraéderessé kezd alakulni. Az XAS spektrumok alapján a második és harmadik koordinációs szférában ez jól megfigyelhető, majd 520 K-nél az első 
koordinációs szférában végbemenő változások is egyértelművé teszik a réteges szerkezet teljes összeomlását.

Olyan réteges kettős hidroxidok esetében ahol az alkáliföldfém $\mathrm{Mg}(\mathrm{II})$ - vagy Ca(II)-ion volt, az optimális szintézis körülmények a „,normál” lúgos tartományba estek. A szintézisparaméterek szisztematikus változtatásával, a keletkezett termékek XRD, TGDTG, SEM, SEM-EDX elemanalízis vizsgálata alapján megállapítható, hogy a $\mathrm{Mg}(\mathrm{II})[\mathrm{Ca}(\mathrm{II})]: \mathrm{Fe}(\mathrm{III})$-tartalmú LDH-k elöállításához együttes lecsapásnál és $\mathrm{CO}_{2}$ mentes környezetben a reakcióelegy végső kémhatása nem haladhatja meg a $p \mathrm{H} 13$-at.

Figyelemre méltó, hogy $\operatorname{Sr}(\mathrm{II}) \mathrm{Fe}(\mathrm{III})-\mathrm{LDH}$ nem keletkezett függetlenül a lecsapáshoz használt lúgkoncentrációtól.

Szerves-szervetlen nanohibridek elöállításához a $\mathrm{Ca}_{3} \mathrm{Fe}-\mathrm{LDH}-\mathrm{t}$, mint hordozóanyagot találtuk a legmegfelelőbbnek. Sokféle szintézismódszert kipróbálva (közvetlen anioncsere, a szerves és a szervetlen sók együttes lecsapása, a gazda LDH dehidratálást követő rehidratálása szerves anionok jelenlétében) az utolsó, a dehidratációsrehidratációs módszer bizonyult a legkedvezőbbnek akrilát[E-3-fenilpropenoát, $E$-3(4'nitrofenil)propenoát, $E-3\left(2^{\prime}, 5^{\prime}\right.$-difluor-fenil)propenoát, $E$-3(4'-klórbenzoil)propenoát, $E$-2ciano-3-fenilpropenoát, E-3(4'-imidazoil)propenoát vagy $\quad E$-3(2'-tie-nil)propenoát]$\mathrm{Ca}(\mathrm{II}) \mathrm{Fe}(\mathrm{III}) \mathrm{LDH}$ előállításához. A rétegek közötti térben a szerves anionok helyzetét az XRD mérések alapján számolt bázislap-távolságok, a becsült rétegvastagság és az akrilát anionok kvantumkémiai módszerrel számolt paraméterei (dimenziói) alapján valószínűsítettem.

Akrilát-Ca(II)Fe(III)-LDH-kat, mint nanoreaktorokat használva fotoiniciált topotaktikus [2+2] ciklizációs reakciók játszódtak le megvilágítás hatására, sok származék esetében $\quad[E$-fenilpropenoát-, $\quad E$-3(4'-nitrofenil)propenoát-, $\quad E$-3(2',5'difluorfenil)propenoate- vagy $E-3(2$ '-tienil)propenoát-Ca(II)Fe(III)-LDH-k] ciklobutánszármazékokat eredményezve a gazdaanyag rétegei közötti terében. A ciklizációs reakciók lejátszódása, illetve eredményessége az $\sim 1560-1640 \mathrm{~cm}^{-1}$ hullámszám-tartományban található $\mathrm{C}=\mathrm{C}$ rezgések változásával jól detektálhatók. A reakció lejátszódása egyben azt is jelentette, hogy az interkalált anionok a rétegek között a megfelelő helyzetben és egymáshoz kellően közel helyezkednek el ahhoz, hogy sikeres legyen a ciklobutánszármazékok képződése.

A különféle mért adatok alapján a E-3(4'-klórbenzoil)propenoát, a E-2-ciano-3fenilpropenoát, az E-2,3-dimetilpropenoát és az E-3(4'-imidazoil)propenoát interkalációja $\mathrm{Ca}(\mathrm{II}) \mathrm{Fe}(\mathrm{III}) \mathrm{LDH}-b a$ egyértelmúen sikeresnek bizonyult, de a rétegközti térben elfoglalt 
helyzetük és/vagy az egymás között lévő távolságuk nem tette lehetővé a topotaktikus reakció lejátszódását. 


\section{REFERENCES}

1. A.C.D. Newman, Chemistry of Clays and Clay Minerals, Wiley-Interscience, New York 1987.

2. $\quad$ D.G. Evans, R.C.T. Slade, Struct. Bond. 119 (2006) 1.

3. F. Cavani, F. Trifirò, A.Vaccari, Catal.Today 11 (1991) 173.

4. A. Vaccari, Catal. Today 41 (1998) 53.

5. $\quad$ R. Allmann, Acta Cryst. B 24 (1968) 972.

6. H.F.W. Taylor, Mineral. Mag. 37 (1969) 338.

7. H.F.W. Taylor, Mineral. Mag. 39 (1973) 377.

8. D. O'Hare, J.S.O. Evans, A. Fogg, S. O’Brien, Polyhedron 19 (2000) 297.

9. M. Shao, J. Han, M. Wei, D.G. Evans, X. Duan, Chem. Eng. J. 168 (2011) 519.

10. E. Manasse, Atti Sot. Toscanu SC. Nat., Proc. Verb. 24 (1915) 92.

11. C. del Hoyo, Appl. Clay Sci. 36 (2007) 103.

12. E.L. Crepaldi, P.C. Pavan, J.B. Valim, J. Braz. Chem. Soc. 11 (2000) 64.

13. M. Meyn, K. Beneke, G. Lagaly, Inorg. Chem. 29 (1990) 5201.

14. A. Corma, V. Fornes, R.M. Martin-Aranda, F. Rey, J. Catal. 134 (1992) 58.

15. W.T. Reichle, S.Y. Kang, D.S. Everhardt, J. Catal. 101 (1986) 352.

16. G. Fornasari, M. Gazzano, D. Matteuzzi, F. Trifirò, A. Vaccari, Appl. Clay Sci. 10 (1995) 69.

17. Y. Zhao, F. Li, R. Zhang, D.G. Evans, X. Duan, Chem. Mater. 14 (2002) 4286.

18. U. Costantino, F. Marmottini, M. Nocchetti, R. Vivani, Eur. J. Inorg. Chem. (1998) 1439.

19. Y. Li, H. Li, M. Yang, X. He, P. Ni, L. Kang, Z.-H. Liu, Appl. Clay Sci. 52 (2011) 51.

20. H.P. Boehn, J. Steinle, C. Vieweger, Angew. Chem. Int. Ed. Engl. 16 (1977) 265.

21. T. Iwasaki, H. Yoshii, H. Nakamura, S. Watano, Appl. Clay Sci. 58(2012)120.

22. G. Lagaly, M. Ogawa, I. Dékány, Handbook of Clay Science, Developments in Clay Science, Elsevier, 2006, Vol. 1, Ch. 7.3. p. 309.

23. W.Y. Tseng, J.T. Lin, C.Y. Mou, S. Cheng, S.B. Liu, P.P. Chu, H.W. Liu, J. Am. Chem. Soc. 118 (1996) 4411.

24. G.A, Bubniak, W.H. Schreiner, N. Mattoso, F. Wypych Langmuir 18 (2002) 5968.

25. S. Miyata, Clays Clay Miner. 28 (1980) 50.

26. D.L. Bish, Bull. Minéral 103 (1980) 175.

27. J.M. Oh, S.H. Hwang, J.H. Choy, Solid State Ionics 151 (2002) 285.

28. H. Xie, Q. Jiao, X. Duan, Chin. J. Appl. Chem. 18 (2001) 70.

29. A.R. Auxilio, P.C. Andrews, P.C. Junk, L. Spiccia, D. Neumann, W. Raverty, N. Vanderhoek, Polyhedron 26 (2007) 3479.

30. L.L. Ren, J. He, S.C. Zhang, D.G. Evans, X. Duan, J. Mol. Catal. B 18 (2002) 3.

31. J. Zhang, F. Zhang, L.L. Ren, D.G. Evans, X. Duan, Mater. Chem. Phys. 85 (2004) 207.

32. M.A. Aramendia, V. Borau, C. Jimenez, J. M. Marinas, J. R. Ruiz, F. J. Urbano J. Solid State Chem. 168 (2002) 156.

33. T. Hibino, Y. Yamashita, K. Kosuge, A. Tsunashima, Clays Clay Miner. 43 (1995) 427.

34. $\quad$ S.K. Yun, T.J. Pinnavaia, Chem. Mater. 7 (1995) 348.

35. F. Prinetto, G. Ghiotti, P. Graffin, D. Tichit, Mic. Mes. Mater. 39 (2000) 229.

36. S. Aisawa, S. Takahashi, W. Ogasawara, Y. Umetsu, E. Narita, J. Solid State Chem. 162 (2001) 52. 
37. Á. Fudala, I. Pálinko, B. Hrivnák, I. Kiricsi, J. Therm. Anal. Cal. 56 (1999) 317.

38. Á. Fudala, I. Pálinkó, I. Kiricsi, J. Mol. Struct. 482/483 (1999) 33.

39. Á. Fudala, I. Pálinkó, I. Kiricsi, Inorg. Chem. 38 (1999) 4653.

40. S. Aisawa, S. Takahashi, W. Ogasawara, Y. Umetsu, E. Narita, Clay Sci. 11 (2000) 317.

41. $\quad$ N.T. Whilton, P.J. Vickers, S. Mann, J. Mater. Chem. 7 (1997) 1623.

42. Q. Yuan, M. Wei, Z.Q. Wang, G. Wang, X. Duan, Clay Clay Miner. 52 (2004) 40.

43. Q. Yuan, M. Wei, D.G. Evans, X. Duan, J. Phys. Chem. B 108 (2004) 12382.

44. S.Y. Kwak, Y.J. Jeong, J.S. Park, J.H. Choy, Solid State Ionics 151 (2002) 229.

45. $\quad$ S.H. Hwang, Y.S. Han, J.H. Choy, Bull. Korean Chem. Soc. 22 (2001) 1019.

46. V. Ambrogi, G. Fardella, G. Grandolini, L. Perioli, Int. J. Pharm. 220 (2001) 23.

47. B.X. Li, J. He, D.G. Evans, X. Duan, Appl. Clay Sci. 27 (2004) 199.

48. B.X. Li, J. He, D.G. Evans, X. Duan, Int. J. Pharm. 287 (2004) 89.

49. W. Kagunya, Z. Hassan, W. Jones, Inorg. Chem. 35 (1996) 5970.

50. S. Velu, R. Veda, A. Ramani, B.M. Chanda, S. Sivasanker, Chem. Commun. (1997) 2107.

51. N. Morel-Desrosiers, J. Pisson, Y. Israëli, C. Taviot-Guého, J.P. Besse, J.P. Morel, J. Mater. Chem. 13 (2003) 2582.

52. Z.P. Xu, P.S. Braterman, J. Mater. Chem. 13 (2003) 268.

53. G.R. Williams, A.J. Norquist, D. O'Hare, Chem. Mater. 16 (2004) 975.

54. J. Wang, M. Wei, R. Rao, D.G. Evans, X. Duan, J. Solid State Chem. 177 (2004) 366.

55. Q.Z. Yang, D.J. Sun, C.G. Zhang, X.J. Wang, W.A. Zhao, Langmuir 19 (2003) 5570 .

56. F. Leroux, P. Aranda, J.P. Besse, E. Ruiz-Hitzky, Eur. J. Inorg. Chem. (2003) 1242.

57. A.I. Khan, L. Lei, A.J. Norquist, D. O’Hare, Chem. Commun. (2001) 2342.

58. M. Wei, S. Shi, J. Wang, Y. Li, X. Duan, J. Solid State Chem. 177 (2004) 2534.

59. J.H. Choy, S.Y. Kwak, J.S. Park, Y.J. Jeong, J. Portier, J. Am. Chem. Soc. 121 (1999) 1399.

60. F. Li, L.H. Zhang, D.G. Evans, C. Forano, X. Duan, Thermochim. Acta 424 (2004) 15.

61. U. Costantino, N. Coletti, M. Nocchetti, C.G. Aloisi, F. Elisei, Langmuir 15 (1999) 4454.

62. U. Costantino, N. Coletti, M. Nocchetti, G.G. Aloisi, F. Elisei, L. Latterini, Langmuir 16 (2000) 10351.

63. J.C. Villegas, O.H. Giraldo, K. Laubernds, S.L. Suib, Inorg. Chem. 42 (2003) 5621.

64. F. Malherbe, J.P. Besse, J. Solid State Chem. 155 (2000) 332.

65. E.A. Gardner, S.K. Yun, T. Kwon, T.J. Pinnavaia, Appl. Clay Sci. 13 (1998) 479.

66. J.J. Bravo-Suárez, E.A. Páez-Mozo, S.T. Oyama, Chem. Mater. 16 (2004) 1214.

67. M. Badreddine, A. Legrouri, A. Barroug, A. de Roy, J.P. Besse, Collect. Czech. Chem. Commun. 63 (1998) 741.

68. M. Badreddine, A. Legrouri, A. Barroug, A. de Roy, J.P. Besse, Mater. Lett. 38 (1999) 391.

69. M.D. Arco, S. Gutierrez, C. Martin, V. Rives, Inorg. Chem. 42 (2003) 4232.

70. V. Prévot, C. Forano, J.P. Besse, J. Solid State Chem. 153 (2000) 301.

71. P. Beaudot, M.E. de Roy, J.P. Besse, J. Solid State Chem. 161 (2001) 332.

72. I. Carpani, M. Berrettoni, B. Ballarin, M. Giorgetti, E. Scavetta, D. Tonelli, Solid State Ionics 168 (2004) 167.

73. S. Bhattacharjee, T.J. Dines, J.A. Anderson, J. Catal. 225 (2004) 398. 
74. V.P. Isupov, L.E. Chupakhina, R.P. Mitrofanova, K.A. Tarasov, A.Y. Rogachev, V.V. Boldyrev, Solid State Ionics 101-103 (1997) 265.

75. A.I. Tsyganok, T. Tsunoda, S. Hamakawa, K. Suzuki, K. Takehira, T. Hayakawa, J. Catal. 213 (2003) 191.

76. P. Beaudot P, M.E. de Roy, J.P. Besse, Chem. Mater. 16 (2004) 935.

77. C. Li, G. Wang, D.G. Evans, X. Duan, J. Solid State Chem. 177 (2004) 4569.

78. M. Jobbágy, A.E. Regazzoni, J. Phys. Chem. B 109 (2005) 389.

79. H. Pfeiffer, E. Lima, V. Lara, J.S. Valente, Langmuir 26 (2010) 4074.

80. J.S. Valente, G. Rodriguez-Gattorno, M. Valle-Orta, E. Torres-Garcia, Mater. Chem. Phys. 133 (2012) 621.

81. S. Velu, C.S. Swamy, Appl. Catal. A 162 (1997) 81.

82. Y. Zhao, Q. Jiao, C. Li, J. Liang, Carbon 45 (2007) 2159.

83. X.D. Li, W.S. Yang, F. Li, D.G. Evans, X. Duan, J. Phys. Chem. Solids 67 (2006) 1286.

84. Y. Seida, Y. Nakano, Y. Nakamura, Water Res. 35 (2001) 2341.

85. J. Das, B.S. Patra, N. Baliarsingh, K.M. Parida, J. Coll. Interface Sci. 316 (2007) 216.

86. Y. Seida, Y. Nakano, Water Res. 36 (2002) 1306.

87. Y. Wu, Y, Yu, J.Z. Zhou, J. Liu, Y. Chi, Z.P. Xu, G. Qian, Chem. Eng. J. 179 (2012) 72.

87. Y. Seida, Y. Nakano, Water Res. 34 (2000) 1487.

88. M.S. Gasser, H.T. Mohsen, H.F. Aly, Coll. Surf. A 331 (2008) 195.

89. Q. Xu, Y. Zhao, Y. Wei, W. Yang, F. Li, M. Gu, Solid State Sci. 10 (2008) 337.

90. M. Taibi, S. Ammar, F. Schoenstein, N. Jouini, F. Fiévet, T. Chauveau, J.M. Greneche J. Phys. Chem. Solids 69 (2008) 1052.

91. B. Rusch, J.-M. R. Génin, C. Ruby, M. Abdelmoula, P. Bonville, Solid State Sci. 10 (2008) 40.

92. K. A. Tarasov, V. P. Isupov, B. B. Bokhonov, Yu.A. Gaponov, B.P. Tolochko, M. M. Yulikov, V.F. Yudanov, A. Davidson, P. Beaunier, E. Marceau, M. Che, Mic. Mes. Mater. 107 (2008) 202.

93. C. Ruby, M. Abdelmoula, R. Aissa, G. Medjahdi, J. Solid State Chem. 181 (2008) 2285.

94. M. Mullet, V. Khare, C. Ruby, Surf. Interface Anal. 40 (2008) 323.

95. Ruby, C., Usman, M., Naille, S., Hanna, K., Carteret, C., Mullet, M., Françoise, M. Abdelmoula, Appl. Clay Sci. 48 (2010) 195.

96. I. Rousselot, C. Taviot-Guého, F. Leroux, P. Léone, P. Palvadeau, J.-P. Besse, J. Solid State Chem. 167 (2002) 137.

97. M.A. Woo, T.W. Kim, M.-J. Paek, H.-W., Ha, J.-H. Choy, S.-J. Hwang, J. Solid State Chem. 184 (2011) 171.

98. W. Meng, F. Li, D.G. Evans, X. Duan, X., Mater. Res. Bull. 39 (2004) 1185.

99. R. Scholder, Angew. Chem. 65 (1953) 240.

100. R. Scholder, E.F. Schwochow, E.F., Angew. Chem. Int. Ed. Engl. 5 (1966) 1047.

101. G. Brauer, (editor) Handbook of Preparative Inorganic Chemistry, Academic Press, New York, London, 1968, Vol. 2, p. 1688. 
102. P. Klán, J. Wirz, Photochemistry of Organic Compounds - From Concepts to Practice, John Wiley \& Sons Ltd., 2009.

103. G.M.J. Schmidt, Pure Appl. Chem. 27 (1971) 647.

104. Y. Sonoda, Molecules 16 (2011) 119.

105. J. Clayden, N. Greeves, S. Warren, Organic Chemistry, Oxford University Press, 2012, 2nd edition, pp. 896-898.

106. G.M.J. Schmidt, J. Chem. Soc. (1964) 2014.

107. S.L. Jenkins, M.J. Almond, S.D.M. Atkinson, M.G.B. Drew, P. Hollins, J.L. Mortimore, M.J. Tobin, J. Mol. Struct. 786 (2006) 220.

108. S.D.M. Allen, M.J. Almond, J.-L. Bruneel A. Gilbert P. Hollins, J. Mascetti, Spectrochim. Acta 56 (2000) 2423.

109. Y.-M. Chi, M. Nakamura, X.-Y. Zhao, T. Yoshizawa, W.-M. Yan, F. Hashimoto, J. Kinjo, T. Nohara, S. Sakurada, Biol. Pharm. Bull. 29 (2006) 580.

110. R. Steri, M. Rupp, E. Proschak, T. Schroeter, H. Zettl, K. Hansen, O. Schwarz, L. Müller-Kuhrt, K.-R. Müller, G. Schneider, M. Schubert-Zsilavecz, Bioorg. Med. Chem. Lett. 20 (2010) 2920.

111. J. Valim, B.M. Kariuki, J. King, W. Jones, Mol. Cryst. Liq. Cryst. 211 (1992) 271.

112. K. Takagi, H. Usami, T. Shiichi, Y. Sawaki, Mol. Cryst. Liq. Cryst. 218 (1992) 109.

113. K. Takagi, T. Shichi, H. Usami, Y. Sawaki, J. Am. Chem. Soc. 115 (1993) 4339.

114. T. Shichi, K. Takagi, Y. Sawaki, Chem. Commun. (1996) 2027.

115. H.C. Greenwell, W. Jones, S.P. Newman, P.V. Coveney, J. Mol. Struct. 647 (2003) 75.

116. F.A. Cotton, G. Wilkinson, Advanced Inorganic Chemistry, Wiley Interscience, New York, $5^{\text {th }}$ edition, 1988, p. 1387.

117. F.A. Cotton, G. Wilkinson, Advanced Inorganic Chemistry, Wiley Interscience, New York, $5^{\text {th }}$ edition, 1988, p. 1388.

118. P. Sipos, D. Zeller, E. Kuzmann, A. Vértes, Z. Homonnay, S. Canton, M. Walczak, Dalton Trans. (2008) 5603.

119. Z. Klencsár, MossWinn 4.0Pre, a software for Mössbauer spectrum analysis, Budapest (Hungary).

120. G.N. George, I. F. Pickering, AXAFSPAK, Stanford Synchrotron Radiation Laboratory, Stanford, CA, 1995, http://www-ssrl.slac.stanford.edu/exafspak.html.

121. J.J. Rehr, J.M. DeLeon, S.I. Zabinsky, R.C. Albers, J. Am. Chem. Soc. 113 (1991) 5135.

122. J.M. DeLeon, J.J. Rehr, S.I. Zabinsky, R.C. Albers, Phys. Rev. B 44 (1991) 4146.

123. J.J.P. Stewart, J. Comput. Chem. 10 (1989) 209.

124. J.J.P. Stewart, J. Comput. Chem. 10 (1989) 221.

125. Hyperchem 8.0, Hypercube, Inc., Gainesville, Florida, 2007.

126. G.W. Brindley, C.-C. Kao, Phys. Chem. Miner. 10 (1984) 187.

127. S. Mandal, S. Mayadevi, Appl. Clay Sci. 40 (2008) 54.

128. V. Rives, Layered Double Hydroxides - Study of layered double hydroxides by thermal methods, Nova Science Publishers, Inc., Huntington, N.Y., 2001, p. 115. 
129. W. Sun, Q. He, L. Lu, H. Liu, Mater. Chem. Phys. 107 (2008) 261.

130. M. Kalinowska, R. Świsłocka, W. Lewandowski, J. Mol. Struct. 834-836 (2007) 572 .

131. S.D.M. Atkinson, M.J. Almond, P. Hollins, S.L. Jenkins, Spectrochim. Acta A 59 (2003) 629. 


\section{ACKNOWLEDGEMENT}

Firstly, let me gratefully acknowledge the immense support and help of Drs István Palinkó and Pál Sipos. My grateful thanks go to them for both the theoretical and practical encouragement and teaching that I have received from them during the years I have spent in their unique research group.

Let me also gratefully acknowledge to all members of the Material and Solution Structure Research Group.

My grateful acknowledgement also goes to the Balassi Institute-Hungarian Scholarship Board Office for their financial support and Dr. Sophie E. Canton and Dörthe Haase. I am also grateful to the MAX-Lab, Lund University and to all who helped me during the months I have spent in Sweden.

I thank to all who helped me in any aspects in- and outside of the University of Szeged.

Finally, many thanks to my family and friends for the tremendous support they gave me in the last years. 